University of Nebraska - Lincoln

DigitalCommons@University of Nebraska - Lincoln

Stratigraphy and palaeoclimatic significance of Late Quaternary loess-palaeosol sequences of the Last Interglacial-Glacial cycle in central Alaska

\author{
Daniel R. Muhs \\ US Geological Survey, dmuhs@usgs.gov \\ Thomas A. Ager \\ US Geological Survey, tager@usgs.gov \\ E. Arthur Bettis III \\ University of lowa, art-bettis@uiowa.edu \\ John McGeehin \\ US Geological Survey \\ Josh M. Been \\ US Geological Survey \\ See next page for additional authors \\ Follow this and additional works at: https://digitalcommons.unl.edu/usgsstaffpub \\ Part of the Earth Sciences Commons
}

Muhs, Daniel R.; Ager, Thomas A.; Bettis, E. Arthur III; McGeehin, John; Been, Josh M.; Begét, James E.; Pavich, Milan J.; Stafford, Thomas W. Jr.; and Stevens, De Anne S. P., "Stratigraphy and palaeoclimatic significance of Late Quaternary loess-palaeosol sequences of the Last Interglacial-Glacial cycle in central Alaska" (2003). USGS Staff -- Published Research. 181.

https://digitalcommons.unl.edu/usgsstaffpub/181

This Article is brought to you for free and open access by the US Geological Survey at DigitalCommons@University of Nebraska - Lincoln. It has been accepted for inclusion in USGS Staff -- Published Research by an authorized administrator of DigitalCommons@University of Nebraska - Lincoln. 


\section{Authors}

Daniel R. Muhs, Thomas A. Ager, E. Arthur Bettis III, John McGeehin, Josh M. Been, James E. Begét, Milan J. Pavich, Thomas W. Stafford Jr., and De Anne S. P. Stevens 


\title{
Stratigraphy and palaeoclimatic significance of Late Quaternary loess-palaeosol sequences of the Last Interglacial-Glacial cycle in central Alaska
}

\author{
Daniel R. Muhs ${ }^{\mathrm{a}, *}$, Thomas A. Ager ${ }^{\mathrm{a}}$, E. Arthur Bettis III ${ }^{\mathrm{b}}$, John McGeehin ${ }^{\mathrm{c}}$, \\ Josh M. Been ${ }^{\mathrm{a}}$, James E. Begét ${ }^{\mathrm{d}}$, Milan J. Pavich ${ }^{\mathrm{c}}$, Thomas W. Stafford Jr. ${ }^{\mathrm{e}}$, \\ De Anne S.P. Stevens ${ }^{\mathrm{f}}$ \\ ${ }^{a}$ US Geological Survey, MS 980, Box 25046, Federal Center, Denver, CO 80225, USA \\ ${ }^{\mathrm{b}}$ Department of Geoscience, University of Iowa, Iowa City, IA 52242, USA \\ ${ }^{\mathrm{c}}$ US Geological Survey, MS 955, National Center, Reston, VA 20192, USA \\ ${ }^{\mathrm{d}}$ Department of Geology and Geophysics, University of Alaska, Fairbanks, AK 99775-5780, USA \\ ${ }^{\mathrm{e}}$ Stafford Research Laboratories, Boulder, CO 80301, USA \\ ${ }^{\mathrm{f}}$ Alaska Division of Geological and Geophysical Surveys, Fairbanks, AK 99775, USA
}

Received 21 July 2001; accepted 6 August 2002

\begin{abstract}
Loess is one of the most widespread subaerial deposits in Alaska and adjacent Yukon Territory and may have a history that goes back $3 \mathrm{Ma}$. Based on mineralogy and major and trace element chemistry, central Alaskan loess has a composition that is distinctive from other loess bodies of the world, although it is quartz-dominated. Central Alaskan loess was probably derived from a variety of rock types, including granites, metabasalts and schists. Detailed stratigraphic data and pedologic criteria indicate that, contrary to early studies, many palaeosols are present in central Alaskan loess sections. The buried soils indicate that loess sedimentation was episodic, or at least rates of deposition decreased to the point where pedogenesis could keep ahead of aeolian input. As in China, loess deposition and pedogenesis are likely competing processes and neither stops completely during either phase of the loess/soil formation cycle. Loess deposition in central Alaska took place before, and probably during the last interglacial period, during stadials of the mid-Wisconsin period, during the last glacial period and during the Holocene. An unexpected result of our geochronological studies is that only moderate loess deposition took place during the last glacial period. Our studies lead us to conclude that vegetation plays a key role in loess accumulation in Alaska. Factors favouring loess production are enhanced during glacial periods but factors that favour loess accumulation are diminished during glacial periods. The most important of these is vegetation; boreal forest serves as an effective loess trap, but sparsely distributed herb tundra does not. Thus, thick accumulations of loess should not be expected where tundra vegetation was dominant and this is borne out by modern studies near the treeline in central Alaska. Much of the stratigraphic diversity of North American loess, including that found in the Central Lowlands, the Great Plains, and Alaska is explained by a new model that emphasizes the relative importance of loess production factors versus loess accumulation factors.

Published by Elsevier Science Ltd.
\end{abstract}

\section{Introduction}

Loess is receiving much attention today in the palaeoclimate community. Not only is loess thought to be a terrestrial equivalent to the foraminiferal oxygen isotope record in deep-sea sediments (Kukla et al., 1988;

\footnotetext{
*Corresponding author. Tel.:+1-303-236-7919; fax: + 1-303-2365349.

E-mail address: dmuhs@usgs.gov (D.R. Muhs).
}

Hovan et al., 1989), but it is also important in setting boundary conditions in atmospheric general circulation models, or AGCMs (Kutzbach et al., 1993). Loess records provide one of the few ways to test reconstruction of paleowinds that are simulated by AGCMs (Muhs and Bettis, 2000). In addition, however, dust is now also being considered as having a role as a climate forcing mechanism itself (Tegen et al., 1996; Mahowald et al., 1999; Kohfeld and Harrison, 2000, 2001; Harrison et al., 2001). Thus, there is considerable interest in loess 
not only as a climate record archive, but for its effects on the overall planetary radiation balance.

In Europe and in parts of the North American midcontinent (see Bettis et al., 2003), the stratigraphic record is straightforward because, in general, loess deposits indicate glacials or stadials while palaeosols indicate interglacials or interstadials (Ruhe, 1983). In China, interpreting loess records is more complex, because loess is deposited during both glacials and interglacials (Kukla et al., 1988; Hovan et al., 1989; Verosub et al., 1993; Ding et al., 1994; Xiao et al., 1995). Therefore, thick unaltered loess deposits represent high rates of loess deposition and palaeosols represent low rates. In Alaska, although loess is thought to be largely glaciogenic, the stratigraphic record may be somewhat analogous to that of China, because loess deposition in Holocene time is well documented (Péwé, 1951, 1975a, b; Begét, 1990; Reger et al., 1996; Manley et al., 2001).
Loess is widely distributed in Alaska, and is areally the most extensive surficial deposit in the state (Fig. 1). Based on studies by Westgate et al. (1990), the Alaskan loess record may extend back to $\sim 3.0 \mathrm{Ma}$. Alaskan loess has been studied for a century, beginning with an investigation by Spurr (1898) in the Yukon River valley. Numerous geomorphic processes have been cited for the origin of upland silt in Alaska, including fluvial, marine, lacustrine, estuarine deposition, and accumulation as residuum from underlying bedrock. However, it was the pioneering work of Péwé (1955) that brought forth a variety of data that now clearly points to an aeolian origin as loess. Since that time, the stratigraphy and palaeoenvironmental significance of loess in Alaska has been studied in a number of regions, but particularly the central interior portion (Figs. 2, 3) of the state (Péwé, 1955, 1975a, b; McCulloch et al., 1965; Hamilton et al., 1983, 1988; Begét, 1988, 1990, 1991, 1996, 2001; Begét

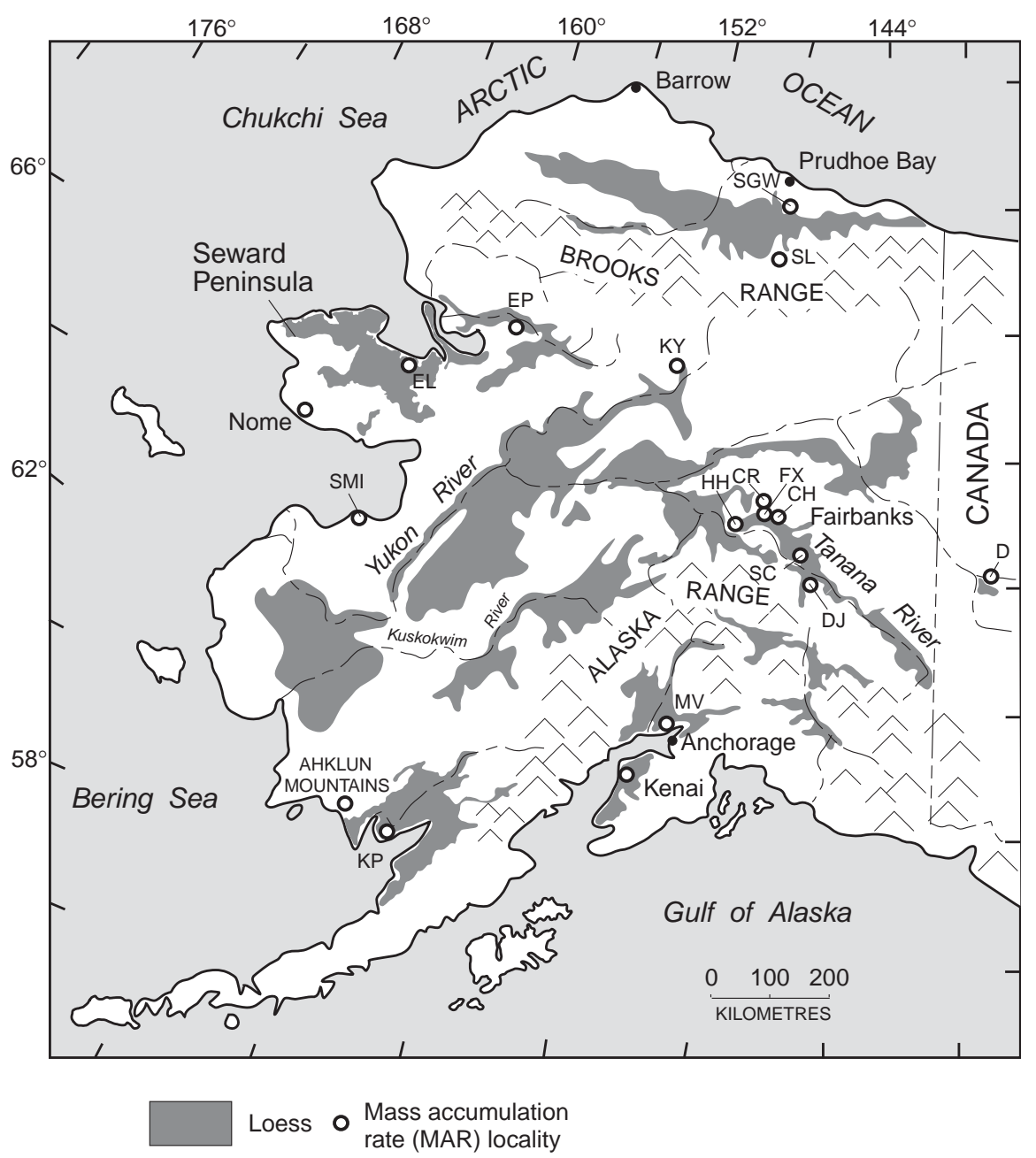

Fig. 1. Map showing the distribution of loess in Alaska (adapted from Hopkins, 1963, for the Seward Peninsula and Péwé, 1975a for the rest of the state) and localities where mass accumulation rates were calculated. Abbreviations: SGW, Sagwon; SL, Slope Mountain; EL, Egg Lake; EP, Epiguruk; KY, Koyukuk; SMI, Saint Michael Island; HH, Halfway House; CR, Chatinika River; FX, Fox; CH, Chena Hot Springs Road; SC, Shaw Creek Flats; DJ, Delta Junction; MV, Matanuska Valley; KP, Kvichak Peninsula. 


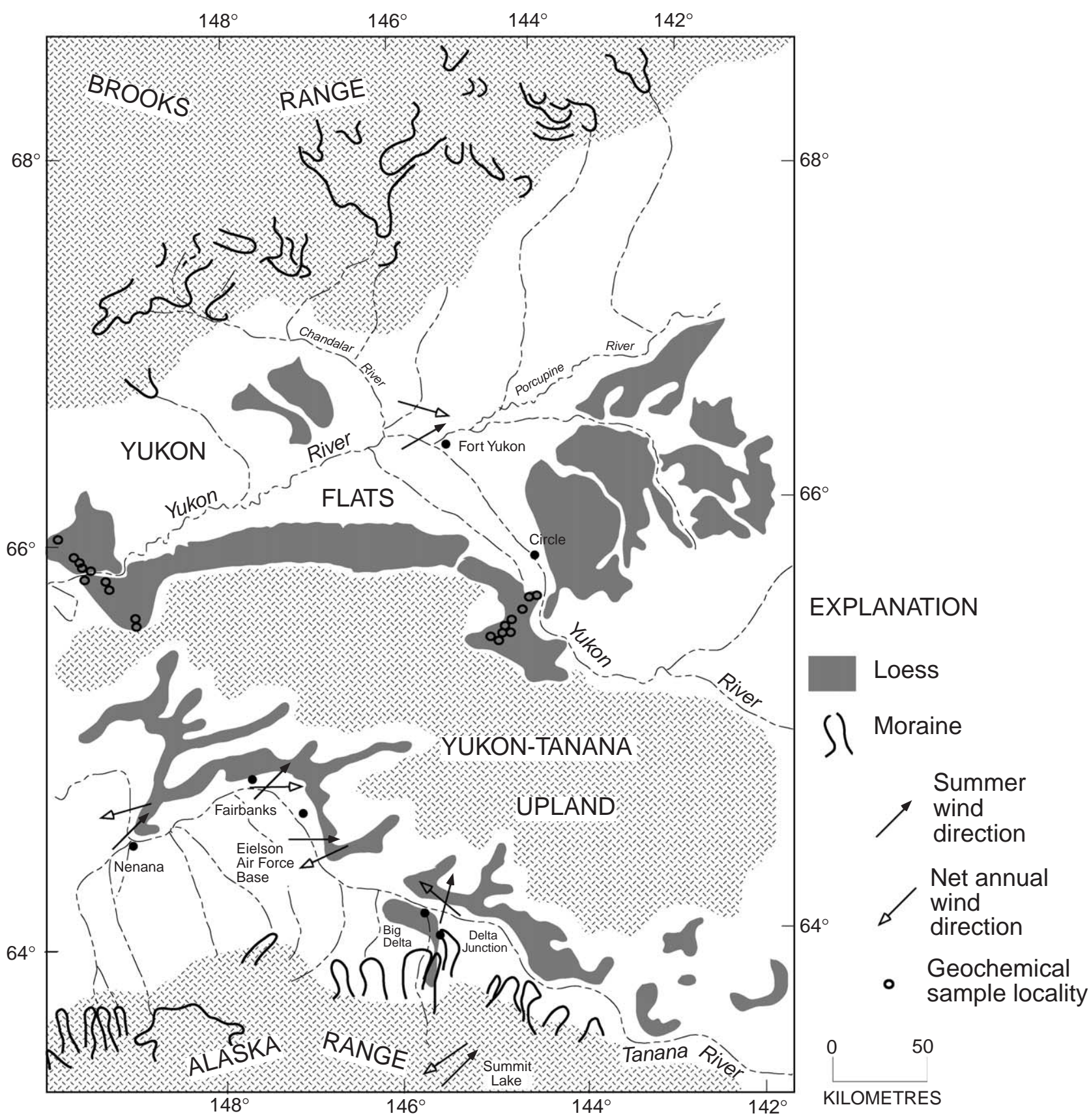

Fig. 2. Map showing the distribution of loess in central Alaska, moraines thought to date from the last glacial period, geochemical sample localities in the Yukon Flats area, and net resultant annual and summer wind directions for wind velocities $\geqslant 5 \mathrm{~m} / \mathrm{s}$. Loess distribution from Péwé et al. (1966), Williams (1962) and minor new mapping by the authors; moraine positions from Karlstrom et al. (1964); resultant wind directions calculated by the authors.

and Hawkins, 1989; Begét et al., 1990; Westgate et al., 1990; Edwards and McDowell, 1991; Berger et al., 1994; Berger et al., 1996; Péwé et al., 1997; Sher et al., 1997; Preece et al., 1999; Vlag et al., 1999; McDowell and Edwards, 2001; Muhs et al., 2001a; Lagroix and Banerjee, 2002).

In this paper, we test several hypotheses about the palaeoclimatic significance of the loess record in central Alaska. The first of these involves two conflicting interpretations about the nature of the loess stratigraphic record in the region. Although loess in Alaska has been studied for decades, there is little or no mention of palaeosols in these deposits (e.g., Péwé, 1955, 1975a, b; Péwé et al., 1997). More recent studies, however, such as those of Hamilton et al. (1988), Begét and Hawkins (1989), Begét et al. (1990), Begét (1990), Hamilton and Brigham-Grette (1991), Vlag et al. (1999), McDowell and Edwards (2001), Muhs et al. (2001a) and Lagroix 


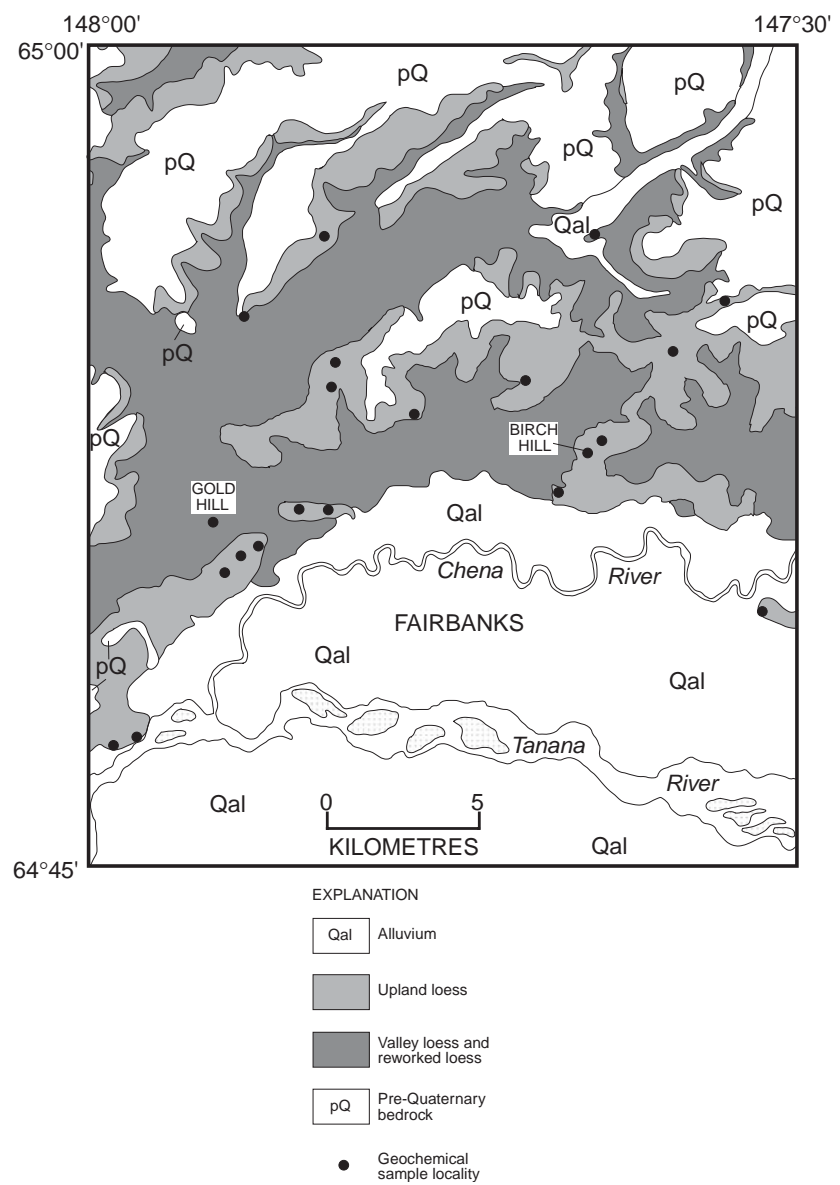

Fig. 3. Map showing the distribution of upland and valley loess in the Fairbanks area (equivalent to the Fairbanks D-2 quadrangle) and geochemical sample localities. Geology redrawn from Péwé (1958).

and Banerjee (2002) report the existence of numerous palaeosols, indicating major periods of little or no loess deposition and relative landscape stability. Similar findings have also been reported for adjacent parts of Yukon Territory in Canada (Fraser and Burn, 1997). We test these conflicting ideas by using established pedologic criteria for the existence of palaeosols in four Alaskan loess sections that we have studied in detail in the Fairbanks area.

New stratigraphic and geochronologic studies of the loess record are also used to test the concept that most loess deposition in Alaska represents glacial periods. This model is a classic one for Alaska (Péwé et al., 1965, 1975a) as well as for the midcontinent of North America (Ruhe, 1983) and Europe (Smalley and Leach, 1978). However, because glaciers still exist in Alaska, glaciogenic silt production and subsequent aeolian entrainment occur today. It is not surprising, therefore, that there is abundant evidence of significant Holocene loess deposition in interior Alaska near Delta Junction (Péwé, 1975a), around Fairbanks (Hamilton et al., 1983, 1988; Begét, 1990), on the Kenai Peninsula (Reger et al.,
1996), and near the Ahklun Mountains in southwestern Alaska (Manley et al., 2001). Dust storms are common at present in the Delta Junction and Matanuska Valley areas of Alaska (Péwé, 1951; Trainer, 1961). In the stratigraphic record, it is not known whether more loess deposition occurred during the last glacial period or the Holocene, but the question is an important one for climate modeling (Mahowald et al., 1999; Kohfeld and Harrison, 2000, 2001; Harrison et al., 2001).

Finally, linked climate-biome-biogeochemical models are now capable of simulating probable dust sources, on a global basis, during the last glacial period (Mahowald et al.,1999; Kohfeld and Harrison, 2000). Simulation of probable dust sources is based on identification of those regions whose earth system properties (strong winds, a decreased intensity of the hydrologic cycle, and a diminished vegetation cover) favour dust entrainment. In the models produced by Mahowald et al. (1999) and reviewed by Kohfeld and Harrison $(2000,2001)$ and Harrison et al. (2001), it is inferred that many high-latitude regions in the Northern Hemisphere, including Alaska, were more important dust sources during the last glacial period than during the Holocene. In addition to new data from the Fairbanks area presented here, we review published stratigraphic and geochronologic data that allow us to calculate mass accumulation rates (MARs) for the last glacial period and the Holocene for various parts of Alaska.

\section{Methods}

\subsection{Analytical techniques}

Detailed stratigraphic and pedologic studies of four thick loess sections were conducted in the Fairbanks area. Studies of modern Alaskan soils by Muhs et al. (2000a) show that certain properties are likely to be the best indicators of pedologic development with which one can identify palaeosols in loess sections. These include field properties such as colour and sequence of genetic horizons, organic matter concentrations, and concentrations of total P. Organic matter concentrations for most sections were determined by a modified Walkley-Black method (for concentrations less than $\sim 7 \%$ ) and by loss-on-ignition at $550^{\circ} \mathrm{C}$ for $\sim 12 \mathrm{~h}$ (for concentrations greater than $\sim 7 \%$ ) (see Allison, 1965). For one section (Chena Hot Springs Road), all organic matter concentrations were estimated by loss-on-ignition $\left(950^{\circ} \mathrm{C}\right.$ for $\left.\sim 1 \mathrm{~h}\right)$. Muhs et al. (2000a) showed that, in non-calcareous loess and palaeosols, there is a very high positive correlation between estimates of organic matter made by the Walkley-Black and loss-on-ignition methods, even for samples with less than $7 \%$ organic matter. Major element concentrations were determined by wavelength-dispersive X-ray fluorescence, where 
precision is typically $\pm 0.01 \%$. Trace element geochemistry, using immobile elements such as $\mathrm{Ti}$ and $\mathrm{Zr}$, is often useful for assessing the uniformity of loess source sediments (see Muhs et al., 1990 for an example of this approach for far-traveled dust). For most samples, concentrations of $\mathrm{Ti}$ and $\mathrm{Zr}$ were determined by energydispersive X-ray fluorescence; for some samples, Ti was determined by wavelength-dispersive $\mathrm{X}$-ray fluorescence. In a comparison of loess of the Fairbanks area with loess of the Yukon Flats area, both selected major elements $(\mathrm{K}, \mathrm{Ca}, \mathrm{Ti})$ and trace elements $(\mathrm{Sr}, \mathrm{Ba}, \mathrm{Zr})$ were determined by energy-dispersive $\mathrm{X}$-ray fluorescence. Particle size analysis of loess and palaeosols was conducted by a combination of sieve and pipette methods. Samples were pre-treated with $\mathrm{H}_{2} \mathrm{O}_{2}$ to destroy organic matter, with $\mathrm{HCl}$ to remove carbonates (although none are typically present) and with $\mathrm{Na}-$ hexametaphosphate to enhance dispersion. Sands (particles with diameters $>53 \mu \mathrm{m}$ ) were separated from silts and clays by wet sieving; abundances of coarse silts (53$20 \mu \mathrm{m})$, fine silts $(20-2 \mu \mathrm{m})$ and clays $(<2 \mu \mathrm{m})$ were determined by settling and pipette analysis. Laboratory precision for pipette analysis was routinely monitored with each suite of sample runs by analysis of an Iowa loess standard maintained by the Department of Agronomy, Iowa State University.

Chronology is based on geochemical identification and correlation of dated tephras, accelerator mass spectrometric (AMS) radiocarbon dating of wood, charcoal, and humic acids from soil organic matter found in loess and buried soil horizons, and ${ }^{10} \mathrm{Be}$ age estimates based on the profile "inventory" method (Curry and Pavich, 1996). AMS radiocarbon ages (Table 1) were determined on wood, charcoal and humic acid extractions from organic matter in palaeosol A horizons. For humic acids, detailed extraction steps are in Abbott and Stafford (1996) and McGeehin et al. (2001), but include the following: (1) removal of material coarser than $63 \mu \mathrm{m}$ by sieving, (2) removal of carbonates by a $6 \mathrm{~N} \mathrm{HCl}$ leach, followed by decantation and centrifuge washing, (3) a $1-5 \% \mathrm{KOH}$ extraction at room temperature, followed by centrifugation to remove clays ( $\sim 30$ min at high speed), and (4) filtration of the supernatant solution through a 0.45 micron teflon millipore filter, followed by acidification. The samples were then dried and graphitized and concentrations of ${ }^{14} \mathrm{C}$ were measured by accelerator mass spectrometry at Lawrence Livermore National Laboratory. Radiocarbon ages were converted to calendar years using the program of Stuiver et al. (1998) for samples less than $\sim 20,000{ }^{14} \mathrm{C}$ yr BP and using the closest calendar-year ages available from Voelker et al. (2000) for samples older than $\sim 20,000{ }^{14} \mathrm{C}$ yr BP (Table 1).

Tephras were identified by major-element geochemistry, using a microprobe, determined on glass fractions isolated from bulk tephra samples (Table 2). Compar- isons were made to published data on glass chemistry for tephras in interior Alaska reported by Westgate et al. (1983, 1985), Begét et al. (1991), Preece et al. (1992), and Berger et al. (1996).

Extraction of ${ }^{10} \mathrm{Be}$ from bulk soil and loess samples follows the method outlined by Curry and Pavich (1996). A calibrated, dissolved spike of ${ }^{9} \mathrm{Be}$ was added to each ground sample, mixed with $\mathrm{NaCO}_{3}$ and heated to $1200^{\circ} \mathrm{C}$ in quartz crucibles. The resulting glass beads were processed chemically to extract a purified $\mathrm{BeO}$ powder. Ratios of ${ }^{10} \mathrm{Be} /{ }^{9} \mathrm{Be}$ in the $\mathrm{BeO}$ powders were measured by accelerator mass spectrometry at Lawrence Livermore National Laboratory. Age estimates were made from ${ }^{10} \mathrm{Be}$ concentrations, horizon thicknesses, bulk densities (volume measured by the tube method; weights determined on $110^{\circ} \mathrm{C}$-oven-dry samples), and estimates of global production rates (Tables 3 and 4).

\subsection{Organic matter and phosphorus distribution in modern soils and palaeosols}

The question of whether or not palaeosols exist in Alaskan loess sections can be answered by use of morphological and chemical properties that are characteristic of modern soils. Three time-tested pedologic methods, supported by studies of modern Alaskan loessderived soils (Muhs et al., 2000a), are employed in this study. The most useful morphological properties are colour, texture, structure, and evidence of subsurface illuviation of mobile soil constituents such as clay or iron. However, many soil morphological properties can be removed by erosion or obscured after burial by diagenetic overprints and cryoturbation. Furthermore, weak soil development may be difficult to discern in loess sequences. Therefore, we also used distribution of organic matter and phosphorus as tests of our field identifications of possible palaeosols based on soil morphology. Distribution of organic matter and phosphorus will not necessarily allow identification of partly eroded soils, but can help confirm the presence of poorly developed soils that have weak morphologic expression.

\subsection{Geochronology of central Alaska tephras}

Several tephras that have been studied in the Fairbanks area are important in loess stratigraphy, and some have been either directly or indirectly dated by numerical methods. The Old Crow tephra has been identified extensively over interior Alaska and Yukon Territory (Westgate et al., 1983, 1985; Begét, 1991; Preece et al., 1992, 1999). Westgate $(1988,1989)$ used the isothermal-plateau fission-track method for analysis of the Old Crow tephra from the Holitna Lowland in southwestern Alaska and the Halfway House section west of Fairbanks. He reported ages of about $150,000 \pm 20,000 \mathrm{yr}$ for two analyses from the Holitna 
Table 1

Accelerator mass spectrometric (AMS) radiocarbon ages of humic acid extractions, charcoal and macrofossils from central Alaskan loess

\begin{tabular}{|c|c|c|c|c|c|c|c|c|}
\hline Locality & Field\# & $\begin{array}{l}\text { Depth in } \\
\text { section (m) }\end{array}$ & Lab\# & LLNL\# & Material & Fraction Modern & $\begin{array}{l}\text { Radiocarbon } \\
\text { age }(\mathrm{yr})\end{array}$ & $\begin{array}{l}\text { Calendar } \\
\text { age }(\mathrm{yr})\end{array}$ \\
\hline Delta Junction & $\begin{array}{l}\text { AK-314-a } \\
\text { AK-314-b } \\
\text { AK-314-c } \\
\text { AK-314-d } \\
\text { AK-314-e } \\
\text { AK-314-f }\end{array}$ & $\begin{array}{l}0.5-0.6 \\
0.9-1.0 \\
1.1-1.2 \\
2.4-2.5 \\
2.9 \\
3\end{array}$ & $\begin{array}{l}\text { NSRL-2807 } \\
\text { NSRL-2808 } \\
\text { NSRL-2809 } \\
\text { NSRL-2810 } \\
\text { NSRL-2811 } \\
\text { NSRL-2812 }\end{array}$ & $\begin{array}{l}\text { CAMS-24347 } \\
\text { CAMS-24348 } \\
\text { CAMS-24349 } \\
\text { CAMS-24350 } \\
\text { CAMS-24351 } \\
\text { CAMS-24352 }\end{array}$ & $\begin{array}{l}\text { Wood } \\
\text { Wood } \\
\text { Wood } \\
\text { Wood } \\
\text { Wood } \\
\text { Humic acids }\end{array}$ & $\begin{array}{l}0.9830 \pm 0.0052 \\
0.9584 \pm 0.0049 \\
0.9256 \pm 0.0043 \\
0.7889 \pm 0.0056 \\
0.7292 \pm 0.0042 \\
0.7180 \pm 0.0061\end{array}$ & $\begin{array}{r}140 \pm 50 \\
340 \pm 50 \\
620 \pm 40 \\
1900 \pm 60 \\
2540 \pm 50 \\
2660 \pm 70\end{array}$ & $\begin{array}{l}294(142) 0 \\
508(356) 294 \\
662(596) 539 \\
1988(1848) 1707 \\
2753(2728) 2363 \\
2919(2761) 2622\end{array}$ \\
\hline $\begin{array}{l}\text { Shaw Creek } \\
\text { Flats }\end{array}$ & $\begin{array}{l}\text { AK-320A } \\
\text { AK-320B }\end{array}$ & $\begin{array}{l}0.33-0.40 \\
0.90-0.93\end{array}$ & $\begin{array}{l}\text { NSRL-2813 } \\
\text { NSRL-2814 }\end{array}$ & $\begin{array}{l}\text { CAMS-24353 } \\
\text { CAMS-24354 }\end{array}$ & $\begin{array}{l}\text { Humic acids } \\
\text { Humic acids }\end{array}$ & $\begin{array}{l}0.9794 \pm 0.0057 \\
0.3067 \pm 0.0027\end{array}$ & $\begin{array}{r}170 \pm 50 \\
9490 \pm 80\end{array}$ & $\begin{array}{l}305(175) 0 \\
11156(10714) 10507\end{array}$ \\
\hline $\begin{array}{l}\text { Halfway House } \\
\text { Nenana- } \\
\text { Fairbanks area }\end{array}$ & $\begin{array}{l}\text { AK-202 } \\
\text { AK-204 } \\
\text { AK-206 } \\
\text { AK-208 } \\
\text { AK-226 } \\
\text { AK-228 } \\
\text { AK-230 } \\
\text { AK-240 }\end{array}$ & $\begin{array}{l}0.15 \\
0.26 \\
0.36 \\
0.53 \\
3.98 \\
4.33 \\
4.6 \\
6.26\end{array}$ & $\begin{array}{l}\text { NSRL-1904 } \\
\text { NSRL-1905 } \\
\text { NSRL-1906 } \\
\text { NSRL-1907 } \\
\text { NSRL-1908 } \\
\text { NSRL-1909 } \\
\text { NSRL-2864 } \\
\text { NSRL-1910 }\end{array}$ & $\begin{array}{l}\text { CAMS-16090 } \\
\text { CAMS- } 16085 \\
\text { CAMS- } 16082 \\
\text { CAMS-16088 } \\
\text { CAMS-16089 } \\
\text { CAMS-16094 } \\
\text { CAMS-24377 } \\
\text { CAMS- } 16095\end{array}$ & $\begin{array}{l}\text { Wood } \\
\text { Humic acids } \\
\text { Humic acids } \\
\text { Wood } \\
\text { Humic acids } \\
\text { Humic acids } \\
\text { Humic acids } \\
\text { Humic acids }\end{array}$ & $\begin{array}{l}0.9795 \pm 0.0066 \\
0.9708 \pm 0.0072 \\
0.9810 \pm 0.0075 \\
0.9848 \pm 0.0074 \\
0.0222 \pm 0.0013 \\
0.0174 \pm 0.0013 \\
0.0268 \pm 0.0010 \\
0.0053 \pm 0.0013\end{array}$ & $\begin{array}{c}170 \pm 60 \\
240 \pm 60 \\
150 \pm 70 \\
120 \pm 70 \\
30,580 \pm 480 \\
32,530 \pm 620 \\
29,080 \pm 300 \\
42,160 \pm 2030\end{array}$ & $\begin{array}{l}310(175) 0 \\
461(294) 1 \\
310(144) 0 \\
302(97) 0 \\
\sim 33,960 \\
\sim 35,780 \\
\sim 33,520 \\
\sim 43,280\end{array}$ \\
\hline $\begin{array}{l}\text { Gold Hill, } \\
\text { Fairbanks area }\end{array}$ & $\begin{array}{l}\text { AK-12 } \\
\text { AK-15 } \\
\text { AK-18 } \\
\text { AK-24 } \\
\text { AK-51 }\end{array}$ & $\begin{array}{l}1.8 \\
2.21 \\
2.46 \\
3.36 \\
7.6\end{array}$ & $\begin{array}{l}\text { NSRL-1898 } \\
\text { NSRL-1899 } \\
\text { NSRL-1900 } \\
\text { NSRL-1901 } \\
\text { NSRL-1903 }\end{array}$ & $\begin{array}{l}\text { CAMS-16093 } \\
\text { CAMS-16092 } \\
\text { CAMS-16091 } \\
\text { CAMS-16084 } \\
\text { CAMS-16083 }\end{array}$ & $\begin{array}{l}\text { Humic acids } \\
\text { Humic acids } \\
\text { Humic acids } \\
\text { Humic acids } \\
\text { Humic acids }\end{array}$ & $\begin{array}{l}0.0213 \pm 0.0013 \\
0.0159 \pm 0.0013 \\
0.0286 \pm 0.0013 \\
0.0078 \pm 0.0014 \\
0.0042 \pm 0.0013\end{array}$ & $\begin{array}{l}30,910 \pm 500 \\
33,280 \pm 680 \\
28,560 \pm 380 \\
39,020 \pm 1420 \\
43,890 \pm 2510\end{array}$ & $\begin{array}{l}\sim 34,240 \\
\sim 36,360 \\
\sim 32,300 \\
\sim 41,740 \\
\sim 43,880\end{array}$ \\
\hline $\begin{array}{l}\text { Birch Hill, } \\
\text { Fairbanks area }\end{array}$ & $\begin{array}{l}\text { AK-714 } \\
\text { AK-717 } \\
\text { AK-719 } \\
\text { AK-719 } \\
\text { AK-730 }\end{array}$ & $\begin{array}{l}3.34 \\
3.65 \\
3.82 \\
3.82 \\
7.76\end{array}$ & $\begin{array}{l}\text { NSRL-2815 } \\
\text { NSRL-2816 } \\
\text { NSRL-2817 } \\
\text { NSRL-2818 } \\
\text { NSRL-2819 }\end{array}$ & $\begin{array}{l}\text { CAMS-24355 } \\
\text { CAMS-24356 } \\
\text { CAMS-24357 } \\
\text { CAMS-24358 } \\
\text { CAMS-24359 }\end{array}$ & $\begin{array}{l}\text { Humic acids } \\
\text { Humic acids } \\
\text { Humic acids } \\
\text { Charcoal } \\
\text { Humic acids }\end{array}$ & $\begin{array}{l}0.0323 \pm 0.0009 \\
0.0137 \pm 0.0008 \\
0.0219 \pm 0.0009 \\
0.0056 \pm 0.0009 \\
0.0083 \pm 0.0008\end{array}$ & $\begin{array}{l}27,580 \pm 220 \\
34,480 \pm 500 \\
30,680 \pm 320 \\
41,600 \pm 1200 \\
38,530 \pm 810\end{array}$ & $\begin{array}{l}\sim 30,180 \\
\sim 40,520 \\
\sim 34,000 \\
\sim 43,000 \\
\sim 41,540\end{array}$ \\
\hline $\begin{array}{l}\text { Chena Hot } \\
\text { Springs Road, } \\
\text { south side cut, } \\
\text { Fairbanks area }\end{array}$ & $\begin{array}{l}\text { AK-900A } \\
\text { AK-900B }\end{array}$ & $\begin{array}{l}0.44 \\
0.98\end{array}$ & $\begin{array}{l}\text { WW-3178 } \\
\text { WW-3179 }\end{array}$ & $\begin{array}{l}\text { CAMS-72995 } \\
\text { CAMS-72996 }\end{array}$ & $\begin{array}{l}\text { Charcoal } \\
\text { Charcoal }\end{array}$ & $\begin{array}{l}0.3580 \pm 0.0012 \\
0.3196 \pm 0.0014\end{array}$ & $\begin{array}{l}8250 \pm 30 \\
9160 \pm 40\end{array}$ & $\begin{array}{l}9400(9167) 9090 \\
10473(10352) 10220\end{array}$ \\
\hline $\begin{array}{l}\text { Chena Hot } \\
\text { Springs Road, } \\
\text { north side cut, } \\
\text { Fairbanks area }\end{array}$ & $\begin{array}{l}\text { Main trench } \\
\text { AK-910A } \\
\text { AK-912A } \\
\text { AK-909zzz } \\
\text { AK-937 } \\
\text { AK-944 } \\
\text { AK-944A }\end{array}$ & $\begin{array}{l}\text { section: } \\
1.26 \\
1.42 \\
2.8 \\
6.35 \\
7.1 \\
7.1\end{array}$ & $\begin{array}{l}\text { WW-3278 } \\
\text { WW-3279 } \\
\text { WW-3251 } \\
\text { WW-3280 } \\
\text { WW-3281 } \\
\text { WW-3182 }\end{array}$ & $\begin{array}{l}\text { CAMS-75000 } \\
\text { CAMS-75001 } \\
\text { CAMS-74440 } \\
\text { CAMS-75002 } \\
\text { CAMS-75003 } \\
\text { CAMS-72999 }\end{array}$ & $\begin{array}{l}\text { Humic acids } \\
\text { Humic acids } \\
\text { Humic acids } \\
\text { Humic acids } \\
\text { Humic acids } \\
\text { Charcoal }\end{array}$ & $\begin{array}{r}0.0239 \pm 0.0005 \\
0.0240 \pm 0.0005 \\
0.0105 \pm 0.0004 \\
0.0099 \pm 0.0005 \\
0.0074 \pm 0.0004 \\
<0.0009 \pm 0.0003\end{array}$ & $\begin{array}{r}30,010 \pm 170 \\
29,950 \pm 160 \\
36,590 \pm 340 \\
37,050 \pm 390 \\
39,380 \pm 490 \\
>55,900\end{array}$ & $\begin{array}{l}9486(9402) 9153 \\
11226(11176) 11136 \\
12327(11813) 11444 \\
\sim 36,220\end{array}$ \\
\hline
\end{tabular}

Lowland samples, and ages of $120,000 \pm 20,000 \mathrm{yr}$ and $160,000 \pm 30,000 \mathrm{yr}$ for two analyses from the Halfway House samples. These ages are in broad agreement with recent TL age determinations of bracketing loess around the Old Crow tephra reported by Berger et al. (1994, 1996), although it should be noted that TL ages older than $\sim 100,000 \mathrm{yr}$ are open to question. Using the partial bleach method, Berger et al. (1994) reported bracketing TL ages of $\geqslant 140,000 \pm 30,000 \mathrm{yr}$ (loess below the Old Crow tephra) and 110,000 $\pm 32,000 \mathrm{yr}$ (loess above the Old Crow tephra) at the Halfway House locality. At Birch Hill, where the Old Crow tephra is also found, Berger et al. (1996) reported TL ages of $144,000 \pm 22,000 \mathrm{yr}$ (loess below the tephra) and 
Table 2

Geochemistry of tephras from the Halfway House, Gold Hill and Chena Hot Springs Road loess sections (all in w\%)

\begin{tabular}{|c|c|c|c|c|c|c|c|c|c|c|c|c|}
\hline $\begin{array}{l}\text { Locality } \\
\text { (UAF \#) }\end{array}$ & $n$ & $\mathrm{Na}_{2} \mathrm{O}$ & $\mathrm{MgO}$ & $\mathrm{Al}_{2} \mathrm{O}_{3}$ & $\mathrm{SiO}_{2}$ & $\mathrm{Cl}$ & $\mathrm{K}_{2} \mathrm{O}$ & $\mathrm{CaO}$ & $\mathrm{TiO}_{2}$ & $\mathrm{Fe}_{2} \mathrm{O}_{3}$ & Total & $\begin{array}{l}\text { Tephra } \\
\text { correlation }\end{array}$ \\
\hline \multicolumn{13}{|l|}{ Halfway House } \\
\hline \multicolumn{13}{|l|}{ AK-232A } \\
\hline (Act 2236) & 11 & 4.25 & 0.5 & 14.38 & 74.42 & 0.14 & 2.03 & 1.61 & 0.34 & 2.32 & 100 & Halfway \\
\hline sd & & 0.13 & 0.04 & 0.23 & 0.32 & 0.01 & 0.07 & 0.09 & 0.09 & 0.13 & & House \\
\hline \multicolumn{13}{|l|}{ AK-254 } \\
\hline (HHOC-2002) & 15 & 3.75 & 0.31 & 13.27 & 75.37 & 0.18 & 3.61 & 1.28 & 0.35 & 1.88 & 100 & Old Crow \\
\hline sd & & 0.15 & 0.03 & 0.25 & 0.3 & 0.04 & 0.13 & 0.16 & 0.11 & 0.27 & & \\
\hline AK-254 & 14 & 3.71 & 0.28 & 13.07 & 75.19 & 0.29 & 3.67 & 1.44 & 0.29 & 2.06 & 100 & Old Crow \\
\hline (HHOC-1990) & & 0.16 & 0.09 & 0.09 & 0.37 & 0.04 & 0.11 & 0.1 & 0.03 & 0.1 & & \\
\hline \multicolumn{13}{|l|}{ sd } \\
\hline \multicolumn{13}{|l|}{ Gold Hill } \\
\hline \multicolumn{13}{|l|}{ AK-48 } \\
\hline (Act 2004) & 4 & 4.53 & 0.55 & 14.24 & 71.74 & 0.1 & 3.55 & 1.8 & 0.69 & 2.79 & 100 & Dome \\
\hline sd & & 0.24 & 0.04 & 1.12 & 0.34 & 0.06 & 0.25 & 0.49 & 0.42 & 0.47 & & \\
\hline \multicolumn{13}{|l|}{ AK-68A } \\
\hline (Act 2241) & 29 & 4.71 & 1.38 & 15.71 & 67.86 & 0.05 & 2.18 & 3.61 & 0.71 & 3.79 & 100 & Unnamed \\
\hline sd & & 0.42 & 0.14 & 0.48 & 0.65 & 0.02 & 0.18 & 0.29 & 0.14 & 0.29 & & $\begin{array}{l}\text { andesitic } \\
\text { tephra }\end{array}$ \\
\hline \multicolumn{13}{|c|}{$\begin{array}{l}\text { Chena Hot Springs } R d \\
\text { AK-944/945 }\end{array}$} \\
\hline (Act 2529) & 17 & 4.58 & 0.51 & 14.62 & 71.22 & 0.11 & 3.74 & 1.8 & 0.54 & 2.88 & 100 & Dome \\
\hline sd & & 0.11 & 0.05 & 0.17 & 0.35 & 0.03 & 0.1 & 0.09 & 0.14 & 0.17 & & \\
\hline
\end{tabular}

$128,000 \pm 22,000 \mathrm{yr}$ (loess above the tephra). At Eva Creek, another locality near Fairbanks, Berger and Péwé (2001) reported a TL age of 136,000 $\pm 20,000 \mathrm{yr}$ for loess above the Old Crow tephra but below the Eva Forest Bed of last-interglacial age. Based on our own studies at Eva Creek, we do not agree that the Old Crow underlies the Eva Forest Bed; our interpretation of the stratigraphy is that the Old Crow tephra is found within the forest bed (Muhs et al., 2001a). Nevertheless, we agree from the multiple analyses by different techniques, along with their associated errors (all given above at only 1-sigma uncertainties), that the Old Crow tephra has a likely age of 160,000-120,000 yr. However, we also believe that the simple averaging practice to yield a reported age of $\sim 140,000 \mathrm{yr}$ is misleading.

The Dome tephra is undated by any direct means. It occurs stratigraphically above the Old Crow tephra at the Eva Creek locality (see Péwé et al., 1997; Muhs et al., 2001a), and is stratigraphically below palaeosols with ages of $\sim 39,000 \mathrm{yr}$ (likely a minimum age) at Gold Hill and $>55,900 \mathrm{yr}$ at the Chena Hot Springs Road sections (see below). Thus, the Dome tephra is younger than $160,000-120,000 \mathrm{yr}$ but older than $\sim 56,000 \mathrm{yr}$. The Halfway House tephra is the least studied of all the named tephras found in the Fairbanks area. It occurs at Halfway House (see discussion below), and is reported as occurring in a trench, distinct from the one in the present study, at Gold Hill (Preece et al., 1999). New TL age estimates at this latter locality suggest that it is older than 76,000 $\pm 10,000 \mathrm{yr}$ (Berger and Péwé, 2001). At Halfway House, it occurs above the Old Crow tephra, but its stratigraphic relation to the Dome tephra is unknown.

\section{Mineralogy and geochemistry of Alaskan loess}

The mineralogy and geochemistry of loess deposits provide important information about loess particle origins, source sediments, geomorphic processes and palaeoclimate. Loess is often perceived to be a rather uniform deposit of silt-sized particles dominated by quartz (Pye, 1987). However, recent studies have shown that the geochemistry of loess from different regions is variable, reflecting diverse origins (Gallet et al., 1998). Even within a given region, such as the North American midcontinent, loess compositions can be quite different (Muhs and Bettis, 2000).

There are very few data on the mineralogical and chemical composition of Alaskan loess deposits. Thus, part of our effort has been to characterize the geochemistry of central Alaskan loess using both major 
Table 3

Horizon thicknesses, ${ }^{10} \mathrm{Be}$ measurements, bulk density (BD) measurements and age estimates for loess and palaeosols at the Halfway House section

\begin{tabular}{|c|c|c|c|c|c|c|c|c|c|c|c|c|}
\hline Sample & Horizon & Depth $(\mathrm{cm})$ & $\begin{array}{l}\text { Horizon } \\
\text { thickness } \\
(\mathrm{cm})\end{array}$ & $\begin{array}{l}\text { Measured }{ }^{10} \mathrm{Be} \\
\left(10^{8} \text { atoms } / \mathrm{g}\right)\end{array}$ & $\begin{array}{l}{ }^{10} \mathrm{Be}, \text { corrected } \\
\left(10^{8} \text { atoms } / \mathrm{g}\right)\end{array}$ & $\begin{array}{l}\text { Bulk density } \\
\left(\mathrm{g} / \mathrm{cm}^{3}\right)\end{array}$ & $\begin{array}{l}\text { Source of BD } \\
\text { measurement }\end{array}$ & $\begin{array}{l}{ }^{10} \mathrm{Be}, \text { corr. } / \text { vol. } \\
\left(10^{8} \text { atoms } / \mathrm{cm}^{3}\right)\end{array}$ & $\begin{array}{l}{ }^{10} \mathrm{Be}, \text { corrected } \\
\left(10^{8} \text { atoms } / \mathrm{cm}^{2}\right. \\
\text { depth interval })\end{array}$ & $\begin{array}{l}{ }^{10} \mathrm{Be} \text { in depth } \\
\text { interval/ } \\
\text { production rate }\end{array}$ & $\begin{array}{l}\text { Age interval } \\
(\mathrm{yr})\end{array}$ & $\begin{array}{l}\text { Cumulative } \\
\text { age (yr) }\end{array}$ \\
\hline AK-208 & $5 \mathrm{Ob}$ & 53 & 20 & 2.08 & 1.928 & 0.36 & Measured & 0.69408 & 13.8816 & 10.678 & 1067.816 & 1067.816 \\
\hline AK-209 & $5 \mathrm{~Eb}$ & 67.5 & 9 & 2.76 & 2.608 & 1.08 & Measured & 2.81664 & 25.34976 & 19.5 & 1949.982 & 3017.798 \\
\hline AK-210 & $5 \mathrm{Bwb}$ & 80 & 16 & 2.29 & 2.138 & 1.43 & Measured & 3.05734 & 48.91744 & 37.629 & 3762.881 & 6780.679 \\
\hline AK-211 & $5 \mathrm{C}$ & 98 & 20 & 0.66 & 0.508 & 1.39 & Measured & 0.70612 & 14.1224 & 10.863 & 1086.339 & 7867.018 \\
\hline AK- 212 & $5 \mathrm{C}$ & 118 & 20 & 0.33 & 0.178 & 1.48 & Measured & 0.26344 & 5.2688 & 4.053 & 405.292 & 8272.31 \\
\hline AK-213 & $5 \mathrm{C}$ & 138 & 20 & 0.27 & 0.118 & 1.4 & Measured & 0.1652 & 3.304 & 2.542 & 254.154 & 8526.464 \\
\hline AK-214 & $5 \mathrm{C}$ & 158 & 20 & 0.28 & 0.128 & 1.4 & Estimated & 0.1792 & 3.584 & 2.757 & 275.692 & 8802.156 \\
\hline AK-215 & $5 \mathrm{C}$ & 178 & 20 & 0.56 & 0.408 & 1.4 & Estimated & 0.5712 & 11.424 & 8.788 & 878.769 & 9680.926 \\
\hline AK-216 & $5 \mathrm{C}$ & 198 & 20 & 0.53 & 0.378 & 1.4 & Estimated & 0.5292 & 10.584 & 8.142 & 814.154 & 10495.08 \\
\hline AK-217 & $5 \mathrm{C}$ & 218 & 20 & 0.57 & 0.418 & 1.4 & Estimated & 0.5852 & 11.704 & 9.003 & 900.308 & 11395.388 \\
\hline AK-218 & $5 \mathrm{C}$ & 238 & 20 & 0.48 & 0.328 & 1.4 & Estimated & 0.4592 & 9.184 & 7.065 & 706.462 & 12101.85 \\
\hline AK-219 & $5 \mathrm{C}$ & 258 & 20 & 0.51 & 0.358 & 1.4 & Estimated & 0.5012 & 10.024 & 7.711 & 771.077 & 12872.927 \\
\hline AK-220 & $5 \mathrm{C}$ & 278 & 20 & 0.5 & 0.348 & 1.4 & Estimated & 0.4872 & 9.744 & 7.495 & 749.539 & 13622.466 \\
\hline AK-221 & $5 \mathrm{C}$ & 298 & 20 & 0.55 & 0.398 & 1.4 & Estimated & 0.5572 & 11.144 & 8.572 & 857.231 & 14479.697 \\
\hline AK-222 & $5 \mathrm{C}$ & 318 & 20 & 0.47 & 0.318 & 1.4 & Estimated & 0.4452 & 8.904 & 6.849 & 684.923 & 15164.62 \\
\hline AK-223 & $5 \mathrm{C}$ & 338 & 20 & 0.38 & 0.228 & 1.4 & Estimated & 0.3192 & 6.384 & 4.911 & 491.077 & 15655.697 \\
\hline AK-224 & $5 \mathrm{C}$ & 358 & 20 & 0.35 & 0.198 & 1.4 & Estimated & 0.2772 & 5.544 & 4.265 & 426.462 & 16082.159 \\
\hline AK-225 & $5 \mathrm{C}$ & 379.5 & 23 & 0.38 & 0.228 & 1.21 & Measured & 0.27588 & 6.34524 & 4.881 & 488.096 & 16570.254 \\
\hline AK-226 & $6 \mathrm{Ab}$ & 397.5 & 12 & 1.53 & 1.378 & 1.17 & Measured & 1.61226 & 19.34712 & 14.882 & 1488.24 & 18058.495 \\
\hline AK-227 & $6 \mathrm{C}$ & 413 & 20 & 0.87 & 0.718 & 1.24 & Measured & 0.89032 & 17.8064 & 13.697 & 1369.723 & 19428.218 \\
\hline AK-228 & $7 \mathrm{Ab}$ & 433 & 20 & 2.13 & 1.978 & 1.2 & Measured & 2.3736 & 47.472 & 36.517 & 3651.693 & 23079.912 \\
\hline AK-229 & $7 \mathrm{Bw} 1 \mathrm{~b}$ & 447 & 8 & 2.43 & 2.278 & 1.34 & Estimated & 3.05252 & 24.42016 & 18.785 & 1878.474 & 24958.386 \\
\hline AK-230 & $7 \mathrm{Bw} 2 \mathrm{~b}$ & 460.5 & 19 & 2.53 & 2.378 & 1.34 & Measured & 3.18652 & 60.54388 & 46.572 & 4657.223 & 29615.609 \\
\hline AK-231 & $7 \mathrm{Bw} 3 \mathrm{~b}$ & 473 & 6 & 0.36 & 0.208 & 1.34 & Estimated & 0.27872 & 1.67232 & 1.286 & 128.64 & 29744.249 \\
\hline AK-232 & $7 \mathrm{C}$ & 484 & 16 & 0.5 & 0.348 & 1.2 & Measured & 0.4176 & 6.6816 & 5.14 & 513.969 & 30258.218 \\
\hline AK-233 & $7 \mathrm{C} 2$ & 505 & 26 & 0.55 & 0.398 & 1.24 & Measured & 0.49352 & 12.83152 & 9.87 & 987.04 & 31245.259 \\
\hline AK-234 & $7 \mathrm{C} 3$ & 540 & 44 & 0.93 & 0.778 & 1.24 & Estimated & 0.96472 & 42.44768 & 32.652 & 3265.207 & 34510.466 \\
\hline AK-235 & $7 \mathrm{C} 4$ & 573 & 22 & 0.7 & 0.548 & 1.24 & Estimated & 0.67952 & 14.94944 & 11.5 & 1149.957 & 35660.423 \\
\hline AK-236 & $7 \mathrm{C} 5$ & 591.5 & 15 & 0.55 & 0.398 & 1.24 & Estimated & 0.49352 & 7.4028 & 5.694 & 569.446 & 36229.869 \\
\hline AK-237 & 7C6 & 603.5 & 9 & 0.89 & 0.738 & 1.24 & Estimated & 0.91512 & 8.23608 & 6.335 & 633.545 & 36863.414 \\
\hline AK-238 & $7 \mathrm{C} 7$ & 613 & 10 & 0.9 & 0.748 & 1.24 & Estimated & 0.92752 & 9.2752 & 7.135 & 713.477 & 37576.891 \\
\hline AK-239 & $7 \mathrm{C} 8$ & 621.5 & 7 & 1.24 & 1.088 & 1.24 & Estimated & 1.34912 & 9.44384 & 7.264 & 726.449 & 38303.341 \\
\hline AK-240 & $8 \mathrm{Ab}$ & 626.5 & 3 & 3 & 2.848 & 1.11 & Measured & 3.16128 & 9.48384 & 7.295 & 729.526 & 39032.867 \\
\hline AK-241 & 8Bwlb & 629.5 & 3 & 1.79 & 1.638 & 1.46 & Estimated & 2.39148 & 7.17444 & 5.519 & 551.88 & 39584.747 \\
\hline AK-242 & $8 \mathrm{Bw} 2 \mathrm{~b}$ & 633 & 4 & 2.69 & 2.538 & 1.46 & Estimated & 3.70548 & 14.82192 & 11.401 & 1140.148 & 40724.895 \\
\hline AK-243 & $8 \mathrm{Bw} 3 \mathrm{~b}$ & 636.5 & 3 & 1.28 & 1.128 & 1.46 & Measured & 1.64688 & 4.94064 & 3.8 & 380.049 & 41104.945 \\
\hline AK-244 & $8 \mathrm{C}$ & 648 & 20 & 1.08 & 0.928 & 1.4 & Measured & 1.2992 & 25.984 & 19.988 & 1998.77 & 43103.714 \\
\hline AK-245 & $8 \mathrm{C}$ & 668 & 20 & 1.02 & 0.868 & 1.33 & Measured & 1.15444 & 23.0888 & 17.761 & 1776.062 & 44879.777 \\
\hline AK-246 & $8 \mathrm{C}$ & 688 & 20 & 1.07 & 0.918 & 1.35 & Measured & 1.2393 & 24.786 & 19.066 & 1906.616 & 46786.392 \\
\hline AK-247 & $8 \mathrm{C}$ & 708 & 20 & 0.83 & 0.678 & 1.35 & Estimated & 0.9153 & 18.306 & 14.082 & 1408.154 & 48194.547 \\
\hline AK-248 & $8 \mathrm{C}$ & 728 & 20 & 0.65 & 0.498 & 1.35 & Estimated & 0.6723 & 13.446 & 10.343 & 1034.308 & 49228.855 \\
\hline AK-249 & $8 \mathrm{C}$ & 748 & 20 & 0.71 & 0.558 & 1.35 & Estimated & 0.7533 & 15.066 & 11.589 & 1158.923 & 50387.778 \\
\hline AK- 250 & $8 \mathrm{C}$ & 768 & 20 & 0.93 & 0.778 & 1.35 & Estimated & 1.0503 & 21.006 & 16.158 & 1615.847 & 52003.625 \\
\hline AK-251 & $8 \mathrm{C}$ & 788 & 20 & 1.05 & 0.898 & 1.35 & Estimated & 1.2123 & 24.246 & 18.651 & 1865.077 & 53868.702 \\
\hline AK-252 & $8 \mathrm{C}$ & 808 & 20 & 0.95 & 0.798 & 1.35 & Estimated & 1.0773 & 21.546 & 16.574 & 1657.385 & 55526.087 \\
\hline AK-253 & $8 \mathrm{C}$ & 828 & 20 & 0.72 & 0.568 & 1.35 & Estimated & 0.7668 & 15.336 & 11.797 & 1179.693 & 56705.78 \\
\hline AK-255 & $8 \mathrm{C}$ & 871 & 20 & 0.33 & 0.178 & 1.35 & Estimated & 0.2403 & 4.806 & 3.697 & 369.692 & 57075.473 \\
\hline AK-256 & $8 \mathrm{C}$ & 891 & 20 & 0.41 & 0.258 & 1.35 & Estimated & 0.3483 & 6.966 & 5.358 & 535.846 & 57611.319 \\
\hline
\end{tabular}


and trace elements, using samples collected from unaltered deposits less than $\sim 30,000 \mathrm{yr}$ old in the Fairbanks area. Loess geochemistry reflects the dominant mineralogy of the sediments. Identifiable minerals in Alaskan loess include quartz, K-feldspar, plagioclase, mica, and small amounts of heavy minerals, but carbonate minerals are generally absent. The abundance of quartz in central Alaskan loess is similar to that found in loess worldwide (Pye, 1987). Mica is abundant in central Alaskan loess and is easily visible even in hand samples. Although central Alaskan loess has both Kfeldspar and plagioclase, plagioclase is by far the more abundant of the two minerals and X-ray diffraction patterns suggest a variable plagioclase composition. Based on about a dozen analyses, clay minerals in central Alaskan loess consist of smectite, chlorite (Mgrich rather than Fe-rich), mica and kaolinite, as well as clay-sized quartz and feldspars, mostly plagioclase.

Loess from Alaska shows differences in overall composition compared with other North American loess bodies (Fig. 4). The immediate source of loess in western Illinois, in the North American midcontinent, is outwash derived from the Laurentide ice sheet that covered much of the region during the last glacial period. In addition to crystalline rocks of the Canadian Shield, the Laurentide ice sheet eroded extensive areas of the midcontinent where Palaeozoic carbonate rocks are exposed. Thus, loess from western Illinois contains large amounts of both dolomite and calcite, reflected in the very high concentrations of $\mathrm{MgO}$ and $\mathrm{CaO}$. The absence of carbonates in central Alaskan loess is seen in the comparatively low concentrations of $\mathrm{MgO}$ and $\mathrm{CaO}$. In contrast, loess in Nebraska, in the western part of the midcontinent, is thought to be derived from nonglaciogenic, volcaniclastic siltstones and other sedimentary rocks of Tertiary age (Aleinikoff et al., 1998). Although these source sediments are calcareous, they do not have the abundant dolomite and calcite found in Laurentide ice sheet-derived tills and outwash deposits. Thus, calcareous loess in Nebraska has, on average, even lower $\mathrm{MgO}$ and $\mathrm{CaO}$ contents than Alaskan loess. Much of the $\mathrm{MgO}$ and $\mathrm{CaO}$ in Alaskan loess is probably found in non-carbonate Ca-bearing minerals such as Ca-plagioclase and perhaps hornblende. Abundant Naplagioclase in Alaskan loess is indicated by fairly high $\mathrm{Na}_{2} \mathrm{O}$ contents, which are higher than those found in either Nebraska or Illinois loess. This interpretation is supported by X-ray diffraction analyses of bulk Alaskan loess, which indicate relatively high plagioclase contents. Alaskan loess $\mathrm{K}_{2} \mathrm{O}$ contents are surprisingly low given the abundance of mica. Loess in Alaska has $\mathrm{K}_{2} \mathrm{O}$ contents similar to Illinois loess and generally lower than Nebraska loess. The low $\mathrm{K}_{2} \mathrm{O}$ contents of Alaskan loess compared to Illinois and Nebraska loess may reflect the near-absence of $\mathrm{K}$-feldspar. Concentrations of $\mathrm{Fe}_{2} \mathrm{O}_{3}$ and $\mathrm{Al}_{2} \mathrm{O}_{3}$ are surprisingly high in Alaskan loess, and are higher than those found in Illinois and Nebraska loess. The differences in concentrations of these two elements for Alaska and Illinois are, in part, simply a reflection of the carbonate mineral "dilution" effect, but this does not explain the differences between Alaska and Nebraska. Although these elements are often highly correlated with clay mineral content (Muhs and Bettis, 2000), particle size analyses (discussed below) indicate that unweathered Alaskan loess consistently has clay contents of less than $6 \%$ and generally only around $3 \%$. These values are much lower than clay contents of Nebraska and Colorado loess (Muhs et al., 1999a; Muhs and Bettis, 2000). Therefore, the high $\mathrm{Fe}_{2} \mathrm{O}_{3}$ and $\mathrm{Al}_{2} \mathrm{O}_{3}$ contents of Alaskan loess are likely due to the presence of relatively large amounts of plagioclase $\left(\mathrm{Al}_{2} \mathrm{O}_{3}\right)$ and Fe-rich minerals other than phyllosilicate clays.

Even within central Alaska, there are significant differences in loess composition. In addition to loess in the Fairbanks area (Fig. 3), we sampled loess in the Yukon Flats area, which lies north of the Yukon Tanana Upland but south of the Brooks Range (Fig. 2). Analysis for several complementary major and trace elements shows that these two loess bodies have significantly different compositions (Fig. 5). Although $\mathrm{K}$ concentrations are similar, $\mathrm{Ba}$, which substitutes for $\mathrm{K}$ in $\mathrm{K}$-bearing minerals, is more abundant in Yukon Flats loess. Fairbanks area loess has higher Ti concentrations and much more variable $\mathrm{Zr}$ concentrations than Yukon Flats loess. Finally, in contrast to Fairbanks area loess, Yukon Flats loess is calcareous, which is reflected in generally higher $\mathrm{Ca}$ concentrations. It is the presence of carbonates that suggests the different origins for the two loess bodies. Fairbanks area loess is found on the northern margin of the Tanana River valley (Fig. 2 ). The two surrounding upland regions, the YukonTanana Upland and the Alaska Ranges, are composed primarily of metamorphic rocks intruded by younger plutonic rocks. Neither area has any significant amount of carbonate rocks. In contrast, the southern Brooks Range has abundant outcrops of carbonate rocks (Dover, 1994), which most likely supplied the carbonates found in Yukon Flats loess. It is interesting to note that $\mathrm{K} / \mathrm{Ba}$ and $\mathrm{Ca} / \mathrm{Sr}$ values in Fairbanks area loess are similar to those in modern dust collected from Alaska Range glaciers, reported by Hinkley (1993) (Fig. 5).

\section{Stratigraphy and geochronology of central Alaska loess}

\subsection{Identification of buried soils}

Loess in central Alaska consists of both direct air-fall silt, found on uplands, and a combination of air-fall and colluvially reworked silt found in valley settings. Péwé et al. (1966) mapped the latter as "perennially frozen 
Table 4

Horizon thicknesses, ${ }^{10} \mathrm{Be}$ measurements, bulk density (BD) measurements and age estimates for loess and palaeosols at the Gold Hill section

\begin{tabular}{|c|c|c|c|c|c|c|c|c|c|c|c|c|}
\hline Sample & Horizon & $\begin{array}{l}\text { Midpoint } \\
\text { depth (cm) }\end{array}$ & $\begin{array}{l}\text { Horizon } \\
\text { thickness } \\
(\mathrm{cm})\end{array}$ & $\begin{array}{l}\text { Measured }{ }^{10} \mathrm{Be} \\
\left(10^{8} \text { atoms } / \mathrm{g}\right)\end{array}$ & $\begin{array}{l}{ }^{10} \mathrm{Be}, \text { corrected } \\
\left(10^{8} \text { atoms } / \mathrm{g}\right)\end{array}$ & $\begin{array}{l}\text { Bulk density } \\
\left(\mathrm{g} / \mathrm{cm}^{3}\right)\end{array}$ & $\begin{array}{l}\text { Source of BD } \\
\text { measurement }\end{array}$ & $\begin{array}{l}{ }^{10} \mathrm{Be} \text {, corr. } / \text { vol. } \\
\left(10^{8} \text { atoms } / \mathrm{cm}^{3}\right)\end{array}$ & $\begin{array}{l}{ }^{10} \mathrm{Be}, \text { corrected } \\
\left(10^{8} \text { atoms } / \mathrm{cm}^{2}\right. \\
\text { depth interval })\end{array}$ & $\begin{array}{l}{ }^{10} \mathrm{Be} \text { in depth } \\
\text { interval/ } \\
\text { production rate }\end{array}$ & $\begin{array}{l}\text { Age interval } \\
\text { (yr) }\end{array}$ & $\begin{array}{l}\text { Cumulative } \\
\text { age (yr) }\end{array}$ \\
\hline AK-1 & $\mathrm{Ol}$ & 6 & 12 & 1.33 & 1.178 & 0.21 & Measured & 0.24738 & 2.96856 & 2.2835 & 228.351 & 228.351 \\
\hline AK-2 & $\mathrm{O} 2$ & 14.5 & 5 & 1.83 & 1.678 & 0.49 & Measured & 0.82222 & 4.1111 & 3.1624 & 316.239 & 544.589 \\
\hline AK-3 & $\mathrm{E}$ & 19 & 3 & 1.44 & 1.288 & 0.7 & Measured & 0.9016 & 2.7048 & 2.0806 & 208.062 & 752.651 \\
\hline AK-4 & Bwl & 24.5 & 7 & 1.93 & 1.778 & 1.07 & Measured & 1.90246 & 13.31722 & 10.244 & 1024.402 & 1777.053 \\
\hline AK-5 & Bw2 & 37.5 & 19 & 1.48 & 1.328 & 1.37 & Measured & 1.81936 & 34.56784 & 26.5907 & 2659.065 & 4436.118 \\
\hline AK-6 & C3 & 57.5 & 21 & 1.03 & 0.878 & 1.46 & Measured & 1.28188 & 26.91948 & 20.7073 & 2070.73 & 6506.848 \\
\hline AK-7 & $\mathrm{C} 3$ & 78.5 & 21 & 0.925 & 0.773 & 1.41 & Measured & 1.08993 & 22.88853 & 17.6066 & 1760.657 & 8267.505 \\
\hline AK-8 & $\mathrm{C} 3$ & 97.5 & 17 & 0.82 & 0.668 & 1.45 & Measured & 0.9686 & 16.4662 & 12.6663 & 1266.631 & 9534.136 \\
\hline AK-9 & $\mathrm{C} 3$ & 130.5 & 20 & 1.045 & 0.893 & 1.3 & Estimated & 1.1609 & 23.218 & 17.86 & 1786.001 & 11320.136 \\
\hline AK-10 & $\mathrm{C} 3$ & 196 & 10 & 1.27 & 1.118 & 1.23 & Measured & 1.37514 & 13.7514 & 10.578 & 1057.8 & 12377.937 \\
\hline AK-11 & $\mathrm{C} 4$ & 204 & 7 & 1.595 & 1.443 & 1.19 & Measured & 1.71717 & 12.02019 & 9.2463 & 924.63 & 13302.567 \\
\hline AK-12 & $2 \mathrm{Ab}$ & 214.5 & 17 & 1.92 & 1.768 & 1.18 & Measured & 2.08624 & 35.46608 & 27.2816 & 2728.161 & 16030.728 \\
\hline AK-13 & $2 \operatorname{Cox}$ & 232.5 & 19 & 1.28 & 1.128 & 1.3 & Measured & 1.4664 & 27.8616 & 21.432 & 2143.201 & 18173.929 \\
\hline AK-14 & $2 \mathrm{Cn}$ & 247 & 12 & 1.945 & 1.793 & 1.28 & Estimated & 2.29504 & 27.54048 & 21.185 & 2118.499 & 20292.428 \\
\hline AK-15 & $3 \mathrm{Ab}$ & 253.5 & 3 & 2.61 & 2.458 & 1.27 & Measured & 3.12166 & 9.36498 & 7.2038 & 720.383 & 21012.811 \\
\hline AK-16 & $3 \mathrm{Bwb}$ & 257.5 & 5 & 1.83 & 1.678 & 1.25 & Estimated & 2.0975 & 10.4875 & 8.0673 & 806.731 & 21819.542 \\
\hline AK-17 & $3 \operatorname{Cox}$ & 266.5 & 13 & 1.78 & 1.628 & 1.19 & Measured & 1.93732 & 25.18516 & 19.3732 & 1937.321 & 23756.863 \\
\hline AK-18 & $4 \mathrm{Ab}$ & 277.5 & 9 & 1.53 & 1.378 & 1.19 & Measured & 1.63982 & 14.75838 & 11.3526 & 1135.26 & 24892.123 \\
\hline AK-23 & 4Bwb & 280 & 12 & 0.725 & 0.573 & 1.24 & Estimated & 0.71052 & 8.52624 & 6.5586 & 655.865 & 25547.988 \\
\hline AK-24 & $5 \mathrm{Ab}$ & 287.5 & 3 & 1.03 & 0.878 & 1.24 & Measured & 1.08872 & 3.26616 & 2.5124 & 251.243 & 25799.231 \\
\hline AK-25 & $5 \operatorname{Cox}$ & 294 & 10 & 0.48 & 0.328 & 1.4 & Measured & 0.4592 & 4.592 & 3.5323 & 353.231 & 26152.462 \\
\hline AK-26 & $5 \mathrm{Cn}$ & 320.5 & 43 & 0.45 & 0.298 & 1.42 & Measured & 0.42316 & 18.19588 & 13.9968 & 1399.683 & 27552.145 \\
\hline AK-27 & $5 \mathrm{Cn}$ & 349 & 14 & 0.42 & 0.268 & 1.42 & Measured & 0.38056 & 5.32784 & 4.0983 & 409.834 & 27961.979 \\
\hline AK-28 & $5 \mathrm{Cn}$ & 367 & 22 & 0.535 & 0.383 & 1.42 & Estimated & 0.54386 & 11.96492 & 9.2038 & 920.379 & 28882.358 \\
\hline AK-29 & $5 \mathrm{Cn}$ & 387 & 18 & 0.65 & 0.498 & 1.42 & Estimated & 0.70716 & 12.72888 & 9.7914 & 979.145 & 29861.503 \\
\hline AK-30 & $5 \mathrm{Cn}$ & 406.5 & 21 & 0.855 & 0.703 & 1.42 & Estimated & 0.99826 & 20.96346 & 16.1257 & 1612.574 & 31474.077 \\
\hline AK-31 & $5 \mathrm{Cn}$ & 430.5 & 27 & 1.06 & 0.908 & 1.42 & Estimated & 1.28936 & 34.81272 & 26.779 & 2677.902 & 34151.979 \\
\hline AK-32 & $6 \mathrm{Ab}$ & 445.5 & 4 & 1.31 & 1.158 & 1.42 & Estimated & 1.64436 & 6.57744 & 5.0596 & 505.957 & 34657.937 \\
\hline AK-33 & $6 \mathrm{C} 1$ & 452.5 & 10 & 0.69 & 0.538 & 1.42 & Estimated & 0.76396 & 7.6396 & 5.8766 & 587.662 & 35245.598 \\
\hline AK-34 & $6 \mathrm{C} 2$ & 466.5 & 20 & 0.675 & 0.523 & 1.42 & Estimated & 0.74266 & 14.8532 & 11.4255 & 1142.554 & 36388.152 \\
\hline
\end{tabular}




\begin{tabular}{|c|c|c|c|c|c|c|c|c|c|c|c|c|}
\hline AK-35 & $6 \mathrm{C} 2$ & 483.5 & 16 & 0.66 & 0.508 & 1.4 & Estimated & 0.7112 & 11.3792 & 8.7532 & 875.323 & 37263.476 \\
\hline AK-36 & $6 \mathrm{C} 2$ & 500 & 17 & 0.65 & 0.498 & 1.35 & Estimated & 0.6723 & 11.4291 & 8.7916 & 879.162 & 38142.638 \\
\hline AK-37 & $6 \mathrm{C} 3$ & 516 & 15 & 0.65 & 0.498 & 1.3 & Estimated & 0.6474 & 9.711 & 7.47 & 747 & 38889.638 \\
\hline AK-38 & $6 \mathrm{C} 3$ & 531.5 & 16 & 0.64 & 0.488 & 1.28 & Measured & 0.62464 & 9.99424 & 7.6879 & 768.788 & 39658.426 \\
\hline AK-39 & $6 \mathrm{C} 4$ & 547.5 & 16 & 0.63 & 0.478 & 1.28 & Estimated & 0.61184 & 9.78944 & 7.5303 & 753.034 & 40411.46 \\
\hline AK-40 & $6 \mathrm{C} 5$ & 562.5 & 14 & 0.63 & 0.478 & 1.28 & Estimated & 0.61184 & 8.56576 & 6.589 & 658.905 & 41070.365 \\
\hline AK-41 & $6 \mathrm{C} 5$ & 581.5 & 24 & 0.62 & 0.468 & 1.28 & Estimated & 0.59904 & 14.37696 & 11.0592 & 1105.92 & 42176.285 \\
\hline AK-42 & $6 \mathrm{C} 5$ & 603.5 & 20 & 0.745 & 0.593 & 1.28 & Estimated & 0.75904 & 15.1808 & 11.6775 & 1167.754 & 43344.039 \\
\hline AK-43 & $6 \mathrm{C} 5$ & 624 & 21 & 0.745 & 0.593 & 1.28 & Estimated & 0.75904 & 15.93984 & 12.2614 & 1226.142 & 44570.181 \\
\hline AK-44 & $6 \mathrm{C} 6$ & 638.5 & 8 & 0.87 & 0.718 & 1.28 & Estimated & 0.91904 & 7.35232 & 5.6556 & 565.563 & 45135.744 \\
\hline AK-45 & $6 \mathrm{C} 7$ & 649.5 & 14 & 1.08 & 0.928 & 1.28 & Estimated & 1.18784 & 16.62976 & 12.7921 & 1279.213 & 46414.957 \\
\hline AK-46 & $6 \mathrm{C} 8$ & 661.5 & 10 & 1.29 & 1.138 & 1.28 & Estimated & 1.45664 & 14.5664 & 11.2049 & 1120.493 & 47535.45 \\
\hline AK-47 & $6 \mathrm{C} 9 / 7 \mathrm{~A} 1 \mathrm{~b}$ & 669.5 & 6 & 1.37 & 1.218 & 1.16 & Measured & 1.41288 & 8.47728 & 6.521 & 652.099 & 48187.548 \\
\hline AK-48 & $6 \mathrm{C} 10 / 7 \mathrm{~A} 2 \mathrm{~b}$ & 677.5 & 10 & 1.84 & 1.688 & 1.28 & Estimated & 2.16064 & 21.6064 & 16.6203 & 1662.031 & 49849.58 \\
\hline AK-49 & $7 \mathrm{~A} 1 \mathrm{~b}$ & 687.5 & 10 & 2.31 & 2.158 & 1.38 & Measured & 2.97804 & 29.7804 & 22.908 & 2290.801 & 52140.38 \\
\hline AK-50 & $7 \mathrm{~A} 2 \mathrm{~b}$ & 699 & 13 & 1.98 & 1.828 & 1.44 & Estimated & 2.63232 & 34.22016 & 26.3232 & 2632.321 & 54772.701 \\
\hline AK-51 & $7 \mathrm{~A} 3 \mathrm{~b}$ & 711.5 & 12 & 2.19 & 2.038 & 1.5 & Measured & 3.057 & 36.684 & 28.2185 & 2821.847 & 57594.548 \\
\hline AK-52 & $7 \mathrm{~A} 4 \mathrm{~b}$ & 725 & 15 & 2.27 & 2.118 & 1.52 & Estimated & 3.21936 & 48.2904 & 37.1465 & 3714.647 & 61309.195 \\
\hline AK-53 & 7Bwlb & 735 & 5 & 2.12 & 1.968 & 1.55 & Measured & 3.0504 & 15.252 & 11.7323 & 1173.231 & 62482.426 \\
\hline AK-54 & $7 \mathrm{Bw} 2 \mathrm{~b}$ & 741 & 7 & 1.45 & 1.298 & 1.55 & Estimated & 2.0119 & 14.0833 & 10.8333 & 1083.331 & 63565.758 \\
\hline AK-55 & $7 \mathrm{Bw} 3 \mathrm{~b}$ & 757.5 & 26 & 1.11 & 0.958 & 1.55 & Estimated & 1.4849 & 38.6074 & 29.698 & 2969.801 & 66535.558 \\
\hline AK-56 & $7 \mathrm{Cl}$ & 780.5 & 20 & 0.64 & 0.488 & 1.56 & Measured & 0.76128 & 15.2256 & 11.712 & 1171.2 & 67706.759 \\
\hline AK-57 & $7 \mathrm{Cl}$ & 806 & 21 & 0.65 & 0.498 & 1.5 & Estimated & 0.747 & 15.687 & 12.0669 & 1206.693 & 68913.451 \\
\hline AK-58 & $7 \mathrm{C} 2$ & 821.5 & 20 & 0.62 & 0.468 & 1.5 & Estimated & 0.702 & 14.04 & 10.8 & 1080 & 69993.452 \\
\hline AK-59 & $7 \mathrm{C} 3$ & 841.5 & 20 & 0.61 & 0.458 & 1.45 & Estimated & 0.6641 & 13.282 & 10.2169 & 1021.693 & 71015.144 \\
\hline AK-60 & $7 \mathrm{C} 4$ & 866.5 & 30 & 0.63 & 0.478 & 1.45 & Estimated & 0.6931 & 20.793 & 15.9946 & 1599.462 & 72614.606 \\
\hline AK-61 & $7 \mathrm{C} 5$ & 891 & 19 & 0.65 & 0.498 & 1.45 & Estimated & 0.7221 & 13.7199 & 10.5538 & 1055.377 & 73669.984 \\
\hline AK-62 & $7 \mathrm{C} 6$ & 908 & 15 & 0.625 & 0.473 & 1.45 & Estimated & 0.68585 & 10.28775 & 7.9137 & 791.366 & 74461.349 \\
\hline AK-63 & $7 \mathrm{C} 7$ & 928 & 25 & 0.6 & 0.448 & 1.45 & Estimated & 0.6496 & 16.24 & 12.4923 & 1249.231 & 75710.58 \\
\hline AK-64 & $7 \mathrm{C} 7$ & 966.5 & 16 & 0.615 & 0.463 & 1.45 & Estimated & 0.67135 & 10.7416 & 8.2628 & 826.277 & 76536.858 \\
\hline AK-65 & $7 \mathrm{C} 8$ & 983.5 & 18 & 0.615 & 0.463 & 1.45 & Estimated & 0.67135 & 12.0843 & 9.2956 & 929.562 & 77466.419 \\
\hline AK-66 & $7 \mathrm{C} 9$ & 1004 & 23 & 0.615 & 0.463 & 1.45 & Estimated & 0.67135 & 15.44105 & 11.8777 & 1187.773 & 78654.193 \\
\hline AK-67 & $7 \mathrm{C} 10$ & 1035 & 39 & 0.63 & 0.478 & 1.45 & Estimated & 0.6931 & 27.0309 & 20.793 & 2079.301 & 80733.493 \\
\hline
\end{tabular}




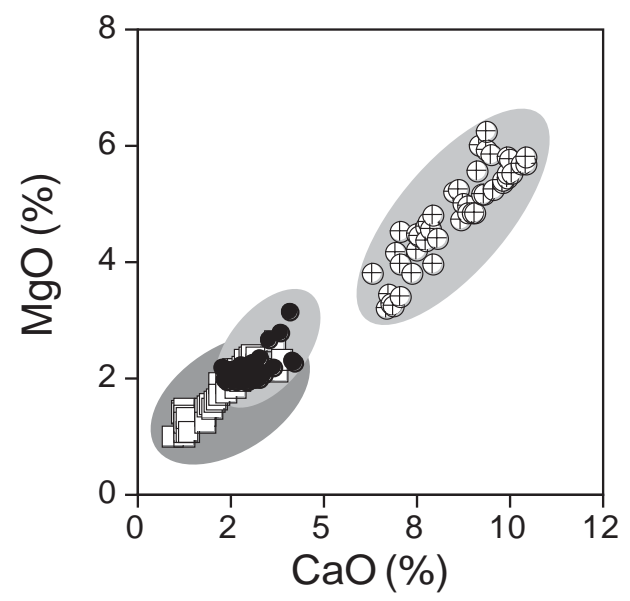

- Central Alaska

$\oplus \quad$ Western Illinois

Eastern Nebraska
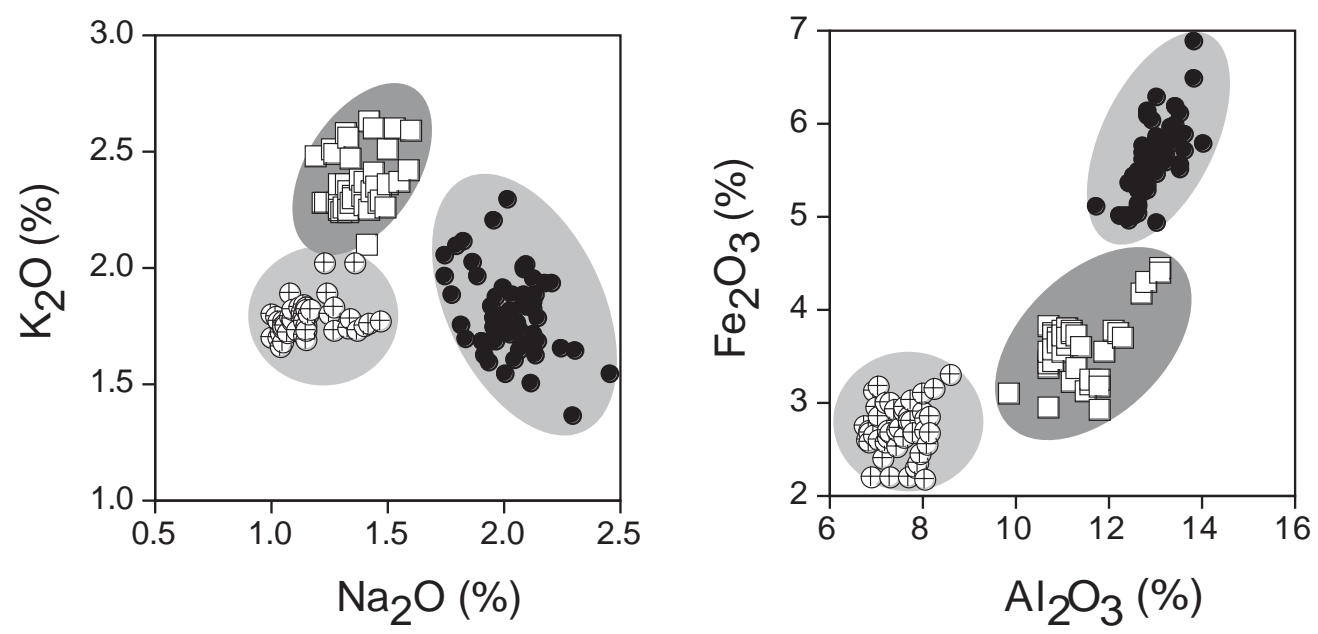

Fig. 4. Plot of major element concentrations in central Alaskan loess (from those samples less than $\sim 30,000 \mathrm{yr}$ old at sections shown in Fig. 6) compared to similar data for loess of last glacial age in western Illinois and eastern Nebraska. Illinois and Nebraska data from Muhs and Bettis (2000).

silt, undifferentiated" and Péwé (1975a, b) refers to the latter as "retransported silt." The implication for both of these descriptors is that the silt found in central Alaskan valleys may be in part direct air-fall loess but also consists of silt that has been transported downslope from upland landscape positions. Péwé (1975a, b) proposes that during the start of interglacial periods, permafrost thawed and considerable silt transport took place downslope by gullying and block slumping. Gullies and channel fills in central Alaskan loess have been described by Sher et al. (1997) and Péwé et al. (1997). For the present study, efforts were concentrated on study of upland loess sites that we regard as wholly or mostly air-fall silt.

Loess stratigraphy was studied at several localities in the Fairbanks area (Fig. 6) in road cuts. The Halfway House locality (Figs. 7, 8) has been previously studied by Westgate et al. (1983), Begét and Hawkins (1989), Begét (1990), Begét et al. (1990), Berger et al. (1994), Vlag et al. (1999) and Lagroix and Banerjee (2002). The localities at Birch Hill (Figs. 9, 10) and on the Chena
Hot Springs Road (Figs. 11, 12) east of Fairbanks, have not been previously studied, nor has the Holocene loess section we examined north of Delta Junction (Figs. 13, 14). Gold Hill (Figs. 15, 16) has been studied by Westgate et al. (1990), Begét (1990), Sher et al. (1997), Oches et al. (1998), Vlag et al. (1999), and Preece et al. (1999). Based on mapping of the loess/silt facies of the Fairbanks area by Péwé et al. (1966), Halfway House, Birch Hill and Chena Hot Springs Road are upland localities that received direct air-fall loess. Gold Hill occurs in what Péwé et al. (1966) mapped as "perennially frozen silt, undifferentiated" and what we refer to as "valley loess and reworked loess" in Fig. 3. However, both we and Sher et al. (1997) interpret Gold Hill to be essentially an upland loess locality, composed primarily of direct, air-fall loess.

What we interpret to be buried soils in central Alaska loess can be identified on the basis of soil morphology, particularly soil colours. Typically, unaltered loess in Alaska has light brownish grey $(2.5 \mathrm{Y} 6 / 2)$, light yellowish brown $(2.5 \mathrm{Y} 6 / 3)$ or greyish brown $(2.5 \mathrm{Y} 5 / 2)$ 

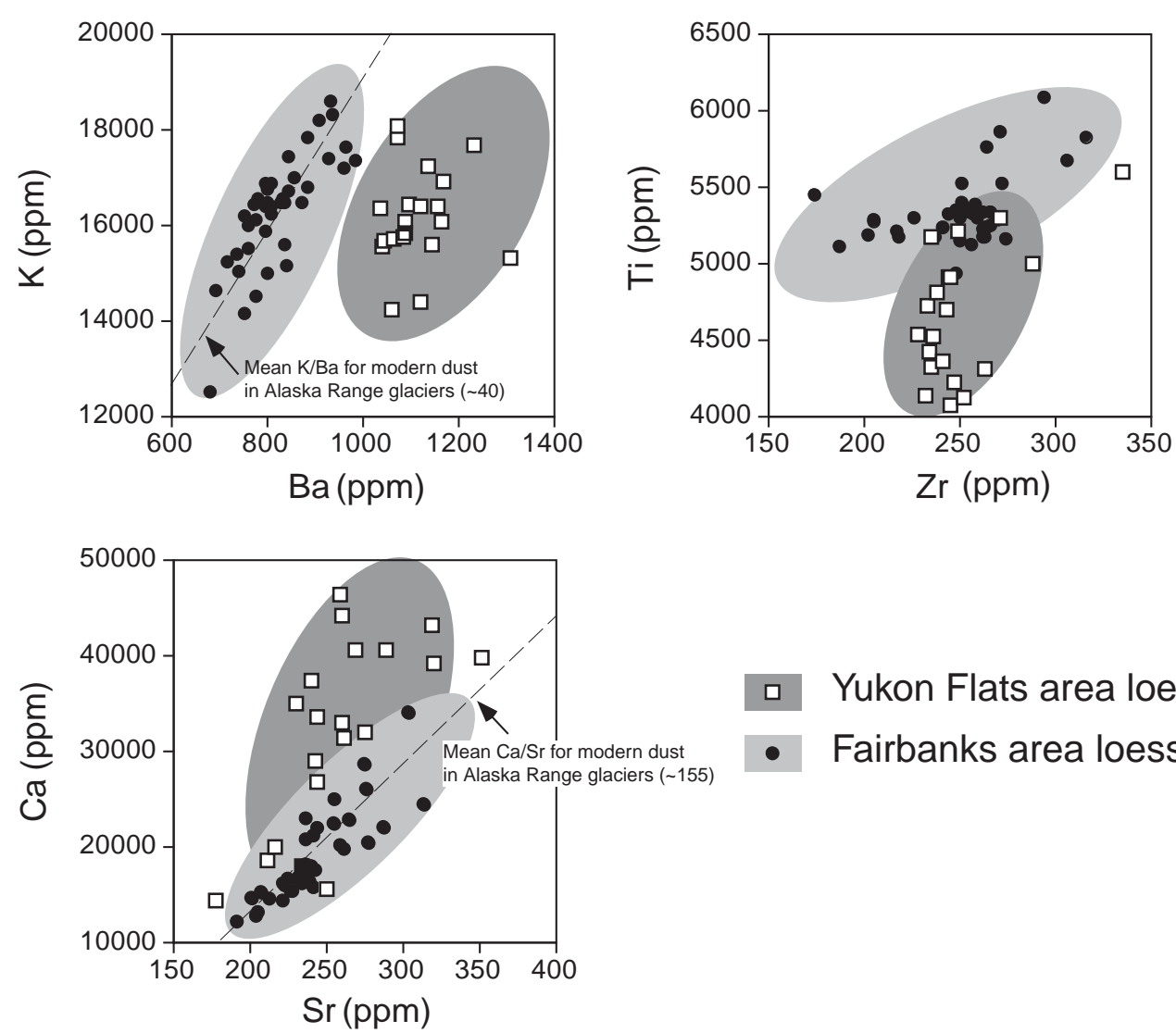

․ Yukon Flats area loess

- Fairbanks area loess

Fig. 5. Plot of element pairs from Fairbanks area loess (localities shown in Fig. 3) and Yukon Flats area loess (localities shown in Fig. 2). Also shown are mean $\mathrm{K} / \mathrm{Ba}$ and $\mathrm{Ca} / \mathrm{Sr}$ values for modern dust collected on glaciers in the Alaska Range (data from Hinkley,1993).

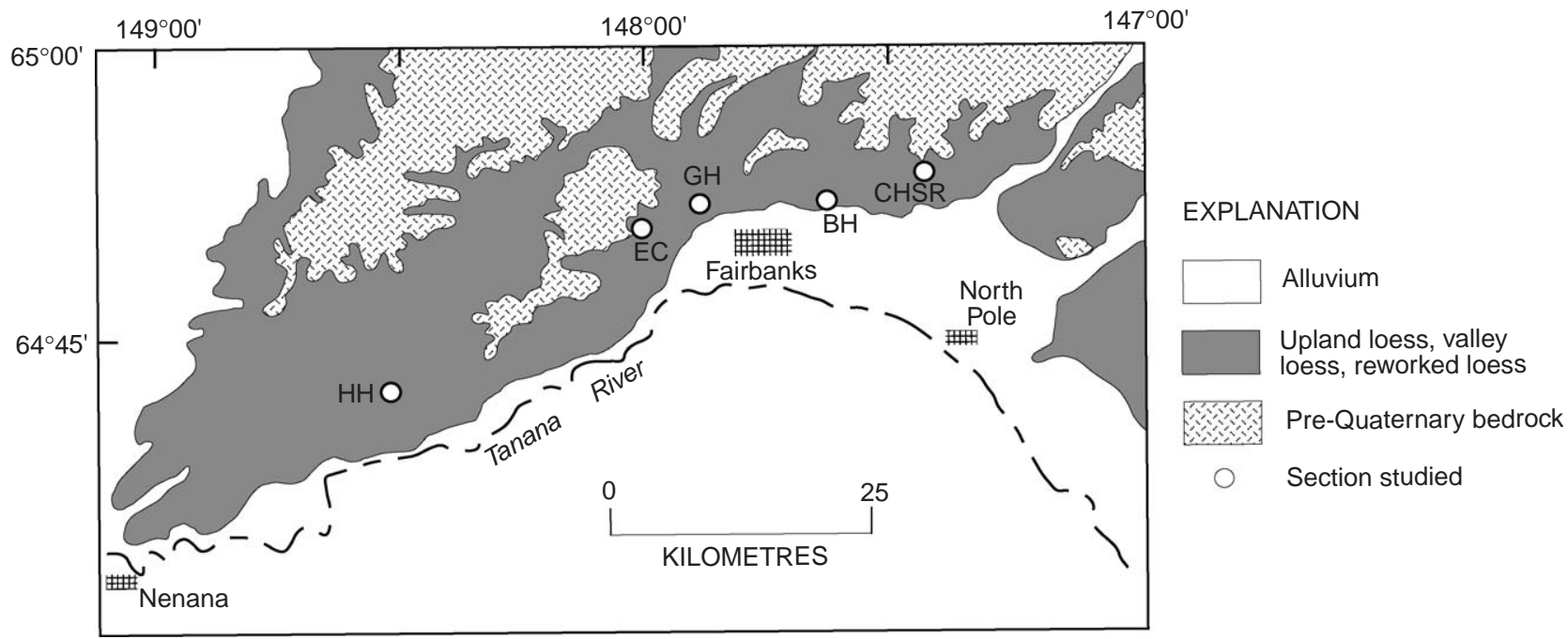

Fig. 6. Map showing the distribution of upland and valley loess in the Fairbanks-Nenana area and locations of sites where stratigraphic studies were conducted. Loess distribution from Péwé et al. (1966). HH, Halfway House; EC, Eva Creek; GH, Gold Hill; BH, Birch Hill; CHSR, Chena Hot Springs Road.

colours, whether moist or dry. Soil O or A horizons generally have $10 \mathrm{YR}$ or $7.5 \mathrm{YR}$ hues and almost always have much lower values and chromas that distinguish them from unaltered loess. Soil B horizons, where they occur, have $10 \mathrm{YR}$ or $7.5 \mathrm{YR}$ hues with chromas that are much higher than unaltered loess.

Organic matter content supports the identification of palaeosols based on field critieria. In all but the 


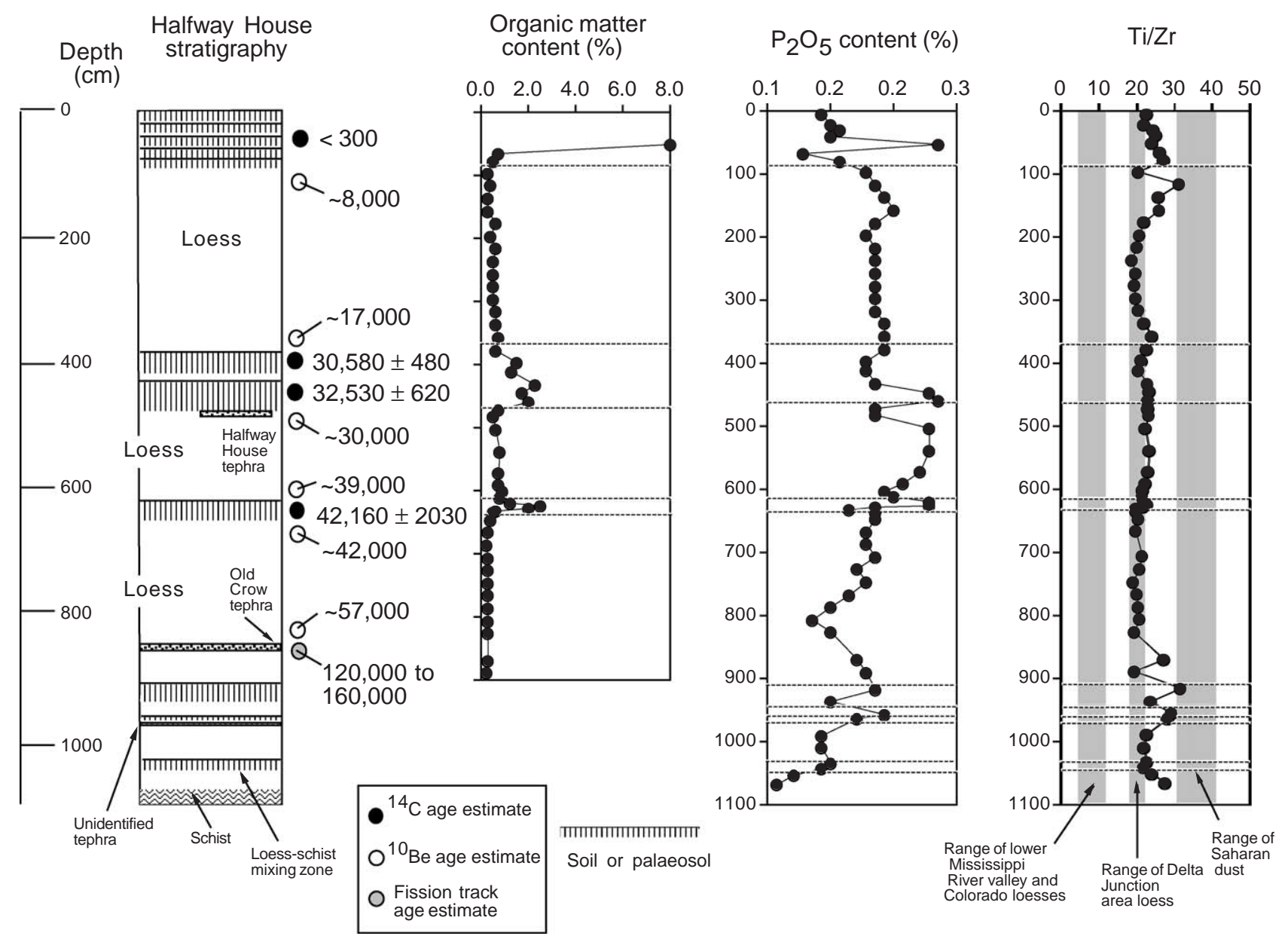

Fig. 7. Loess stratigraphy, radiocarbon ages, and selected ${ }^{10} \mathrm{Be}$ age estimates at the Halfway House section; fission-track age estimate for the Old Crow tephra is from Westgate (1988). Also shown for comparison are plots of organic matter and $\mathrm{P}_{2} \mathrm{O}_{5}$ concentrations, and $\mathrm{Ti} / \mathrm{Zr}$ values as a function of depth in this section. All radiocarbon ages are humic acid extractions. Ranges of Ti/Zr in Mississippi River Valley and Nebraska loess from Pye and Johnson (1988), Muhs and Zárate (2000), and Muhs et al. (2001b); range of Delta Junction loess from this study; range of Saharan dust calculated by Muhs et al. (1990) from data in Glaccum (1978).

lowermost (and therefore oldest) parts of the Gold Hill and Birch Hill sections, units identified as palaeosols have higher organic matter contents relative to superjacent and subjacent loess (Figs. 7, 9, 11, 14, 15). Muhs et al. (2000a) showed that organic matter content in modern Alaskan soils, whether developed under tundra, boreal forest or coastal forest, shows maximum values in the $\mathrm{O}$ or $\mathrm{A}$ horizons which diminish rapidly as a function of depth. A depth function of this form is typical of mid-latitude and low-latitude soils as well (Jenny, 1980), and is a useful criterion to distinguish organic-rich soil horizons from organic-rich lacustrine or fluvial sediments, which may show less dramatic or less systematic declines as a function of depth. In the Halfway House, Birch Hill, and Gold Hill sections, background levels of organic matter in unaltered loess are generally $0.5 \%$ or less, whereas what we have identified as palaeosols usually contain at least $1 \%$ and usually $2 \%$ or more. At Chena Hot Springs Road, background levels of organic matter in loess appear to be much higher $(2-3 \%)$ than at the other sections, although this may be, in part, a function of the fact that these samples were measured by loss-on-ignition at $950^{\circ} \mathrm{C}$ rather than by using either the Walkley-Black or loss-on-ignition at $550^{\circ} \mathrm{C}$ methods, as part of the bulk geochemical analyses. Nevertheless, what we identify as palaeosols in the field have even higher values (4-6\%), indicating that, using either method of estimating organic matter content, relative differences are of value in confirming the presence of palaeosols.

Total phosphorus content (expressed as $\mathrm{P}_{2} \mathrm{O}_{5}$ ) also supports the field identification of buried soils (Figs. 7, $9,11,15)$. In mid-latitude soils, total $\mathrm{P}$ typically shows enrichment at the surface (due to biocycling), depletion just below this zone (due to both leaching and plant uptake), and relatively high values below the zone of depletion, where neither leaching nor plant uptake of $P$ are active processes (Runge et al., 1974). Because this "high-low-high" depth function is not known to be produced by anything other than pedogenic processes, 


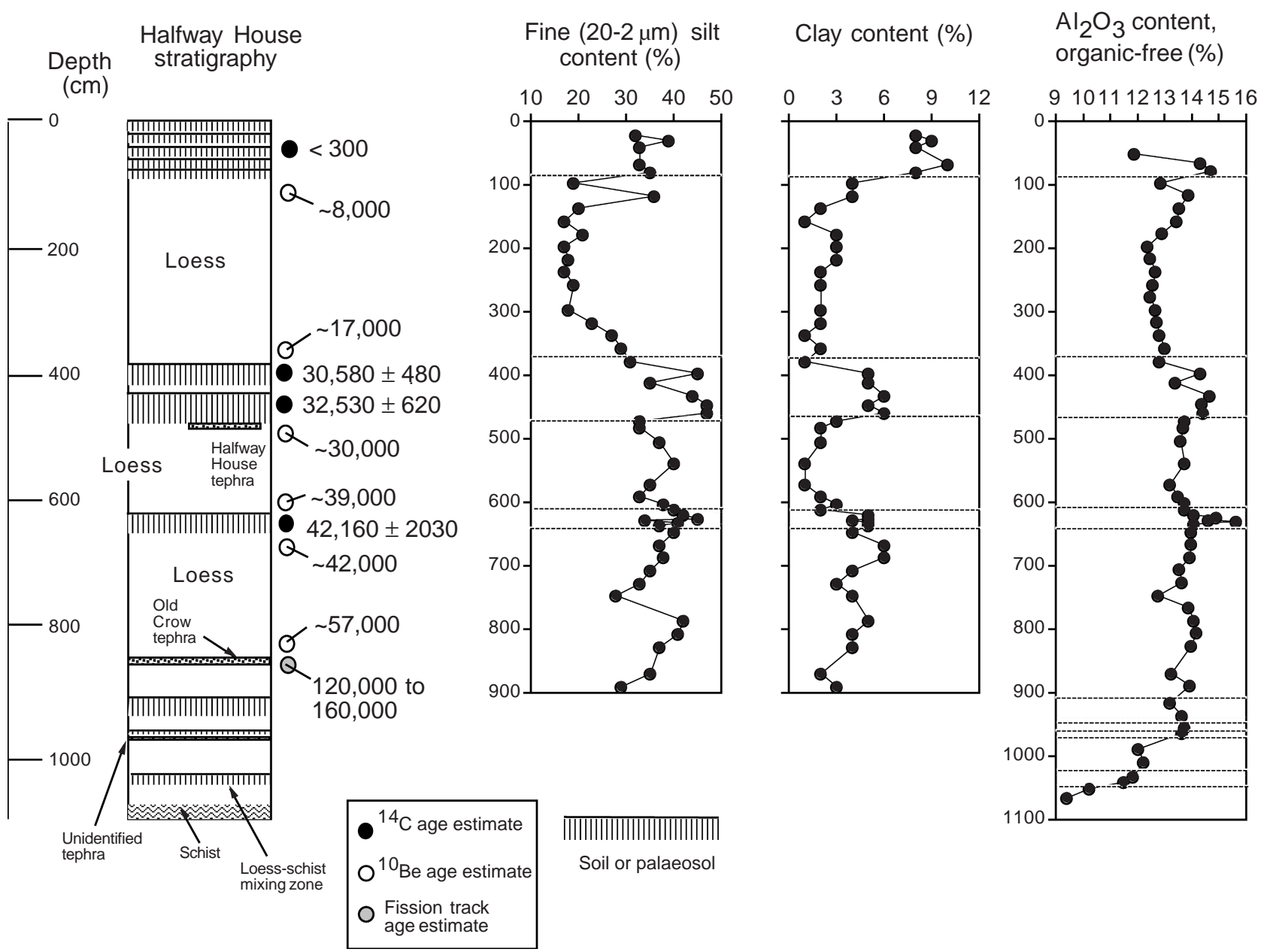

Fig. 8. Plots of fine silt, clay, and $\mathrm{Al}_{2} \mathrm{O}_{3}$ concentrations as a function of depth in the Halfway House section.

Runge et al. (1974) used it with considerable success to identify paleosols in loess sequences in New Zealand. Muhs et al. (2000a) demonstrated that modern Alaskan soils developed under boreal forest showed a similar sort of depth function; however, most modern tundra soils show only an enrichment in the uppermost $\mathrm{O}$ or $\mathrm{A}$ horizons. Thus, zones within loess that show a "highlow-high" depth function can be interpreted unambiguously as buried soils. Zones that show only a $\mathrm{P}_{2} \mathrm{O}_{5}$ enrichment could be interpreted as either buried tundra soils or perhaps minimally developed boreal forest soils. If there is evidence of $\mathrm{P}$ depletion relative to the underlying loess, such a zone could be interpreted as an eroded palaeosol, lacking the $\mathrm{P}$-enriched $\mathrm{O}$ or $\mathrm{A}$ horizon. Results from the present study show that many features identified in the field as buried soils at Halfway House, Gold Hill, Birch Hill and Chena Hot Springs Road show the typical "high-low-high" depth function or an enrichment at the surface. The P data show that even deeply buried soils that lack significant organic matter accumulation, such as the deepest soil complex studied (at $\sim 18 \mathrm{~m}$ ) at Gold Hill, show the pedogenic "high-low-high" depth function. This observation underscores the importance of using more than one criterion for identifying buried soils. In addition, at Halfway House, there is a zone of $\mathrm{P}$ depletion at $\sim 8 \mathrm{~m}$ depth that is neither apparent in the field nor apparent from the organic matter abundances. The zone of $\mathrm{P}$ depletion suggests the presence of the lower part of an eroded palaeosol, perhaps one that is minimally developed and therefore lacks morphological expression.

\subsection{Radiocarbon ages of humic acids, charcoal and wood}

Wood, charcoal and humic acids from the organic matter in palaeosol $\mathrm{O}$ or $\mathrm{A}$ horizons were used to generate radiocarbon age estimates of the times of loess deposition and pedogenesis. These materials differ in the degree of confidence with which one can interpret ages. Well-preserved charcoal, wood or other plant macrofossils yield the most reliable radiocarbon ages, but in the absence of these materials, particularly in welldrained upland loess sections, humic acid extractions 

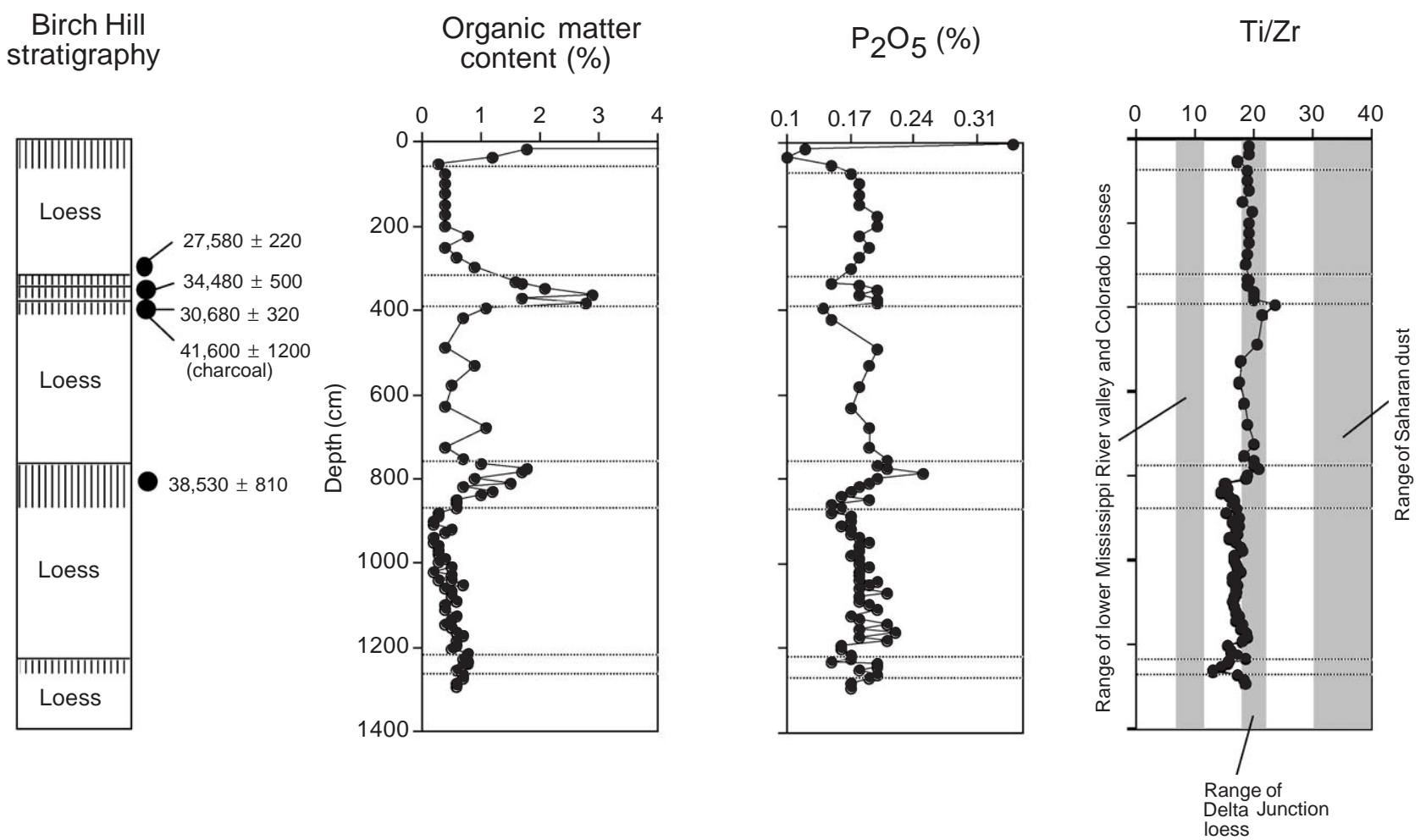

Fig. 9. Loess stratigraphy and radiocarbon ages at the Birch Hill section. Also shown for comparison are plots of organic matter and $\mathrm{P}_{2} \mathrm{O}_{5}$ concentrations, and $\mathrm{Ti} / \mathrm{Zr}$ values as a function of depth in this section. All radiocarbon ages are humic acid extractions except as indicated. Sources of $\mathrm{Ti} / \mathrm{Zr}$ ranges for other aeolian sediments as in Fig. 7.
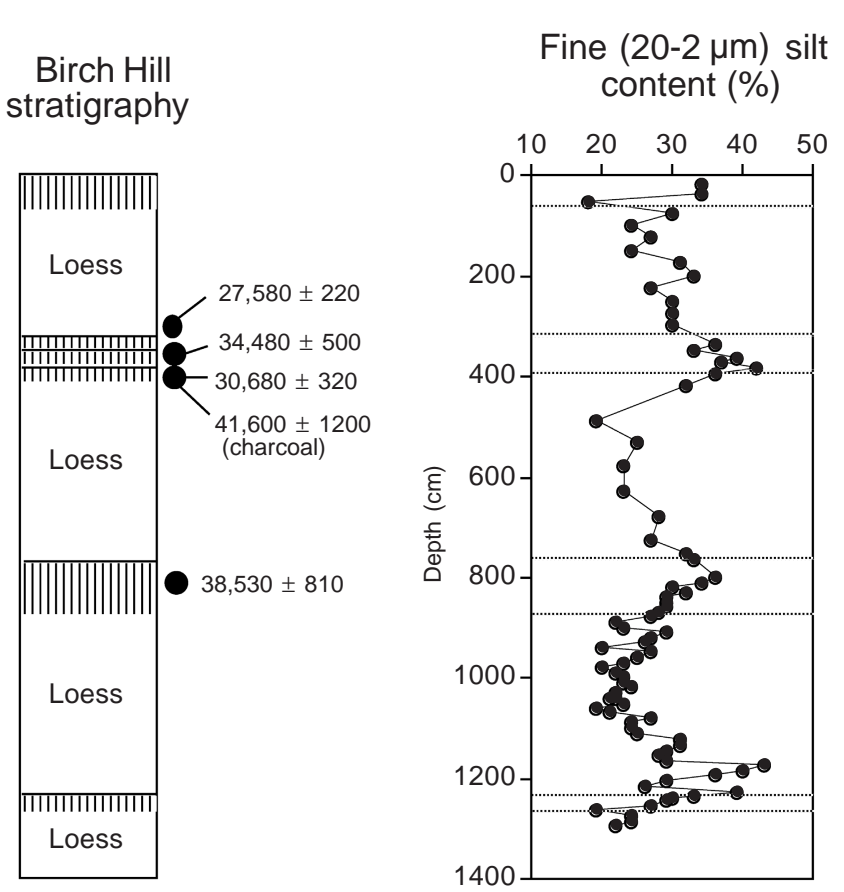

\section{Clay content (\%)}

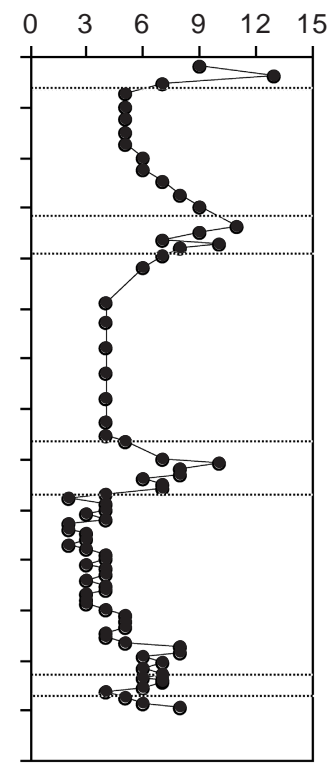

$\mathrm{Al}_{2} \mathrm{O}_{3}$ content, organic-free(\%)

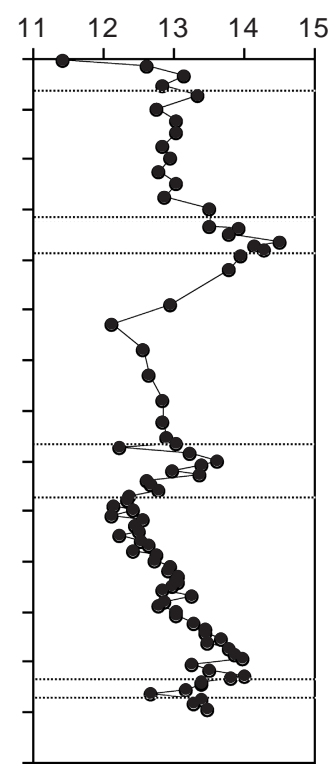

Fig. 10. Plots of fine silt, clay, and $\mathrm{Al}_{2} \mathrm{O}_{3}$ concentrations as a function of depth in the Birch Hill section.

from soil organic matter provide a possible means of estimating ages, if organic matter is sufficiently well preserved. Abbott and Stafford (1996) showed that, in many cases, well-preserved organic matter yields humic acids whose radiocarbon ages are in reasonable agreement with those of plant macrofossils. McGeehin et al. 

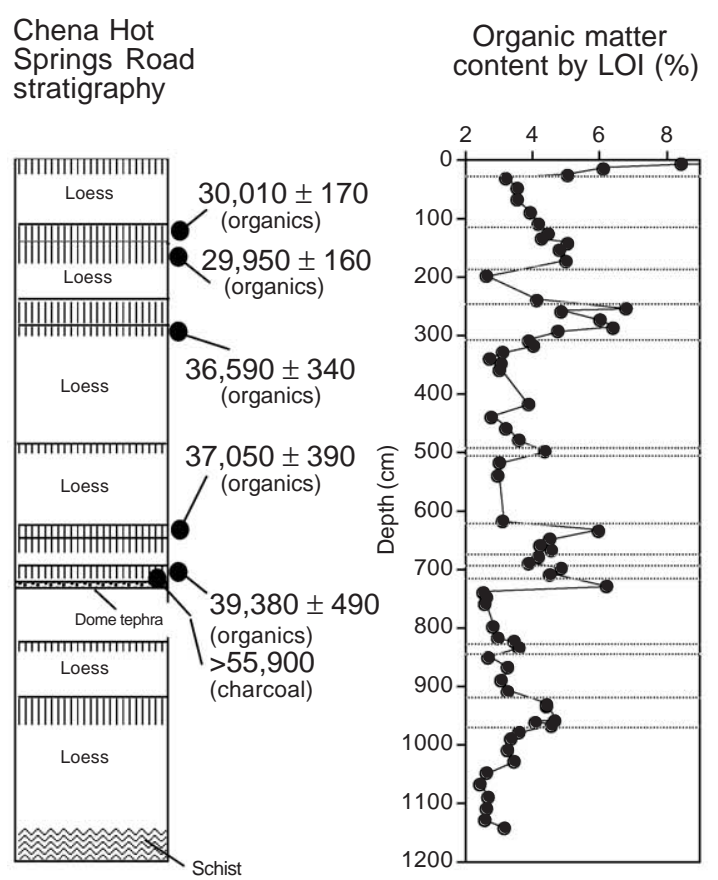

$$
\mathrm{P}_{2} \mathrm{O}_{5}(\%)
$$
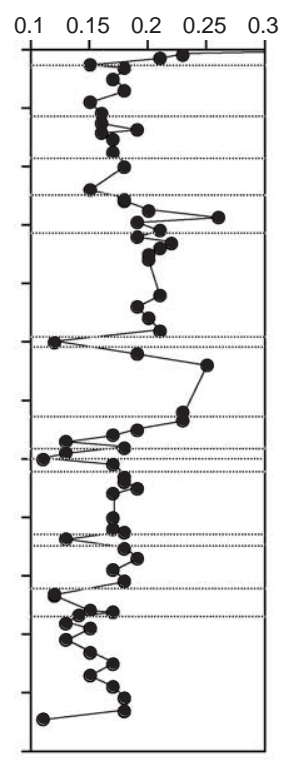

$\mathrm{Al}_{2} \mathrm{O}_{3}$ content,

organic-free (\%)

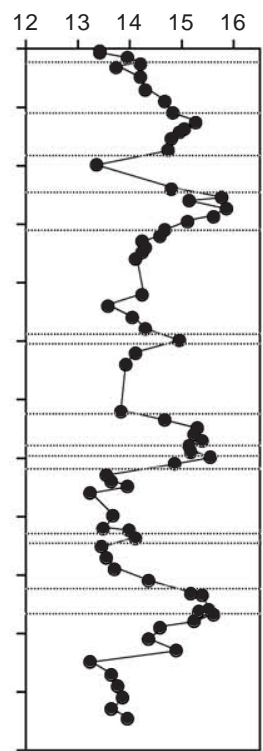

$\mathrm{Ti} / \mathrm{Zr}$

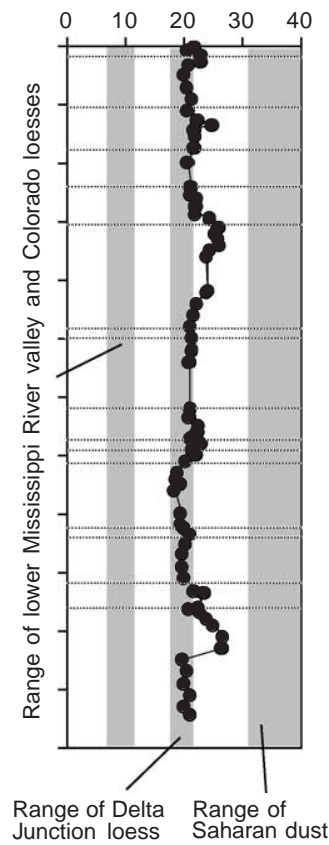

Fig. 11. Loess stratigraphy and radiocarbon ages at the Chena Hot Springs Road section. Also shown for comparison are plots of organic matter and $\mathrm{P}_{2} \mathrm{O}_{5}$ concentrations, $\mathrm{Al}_{2} \mathrm{O}_{3}$ concentrations, and $\mathrm{Ti} / \mathrm{Zr}$ values as a function of depth in this section. Sources of $\mathrm{Ti} / \mathrm{Zr}$ ranges for other aeolian sediments as in Fig. 7.

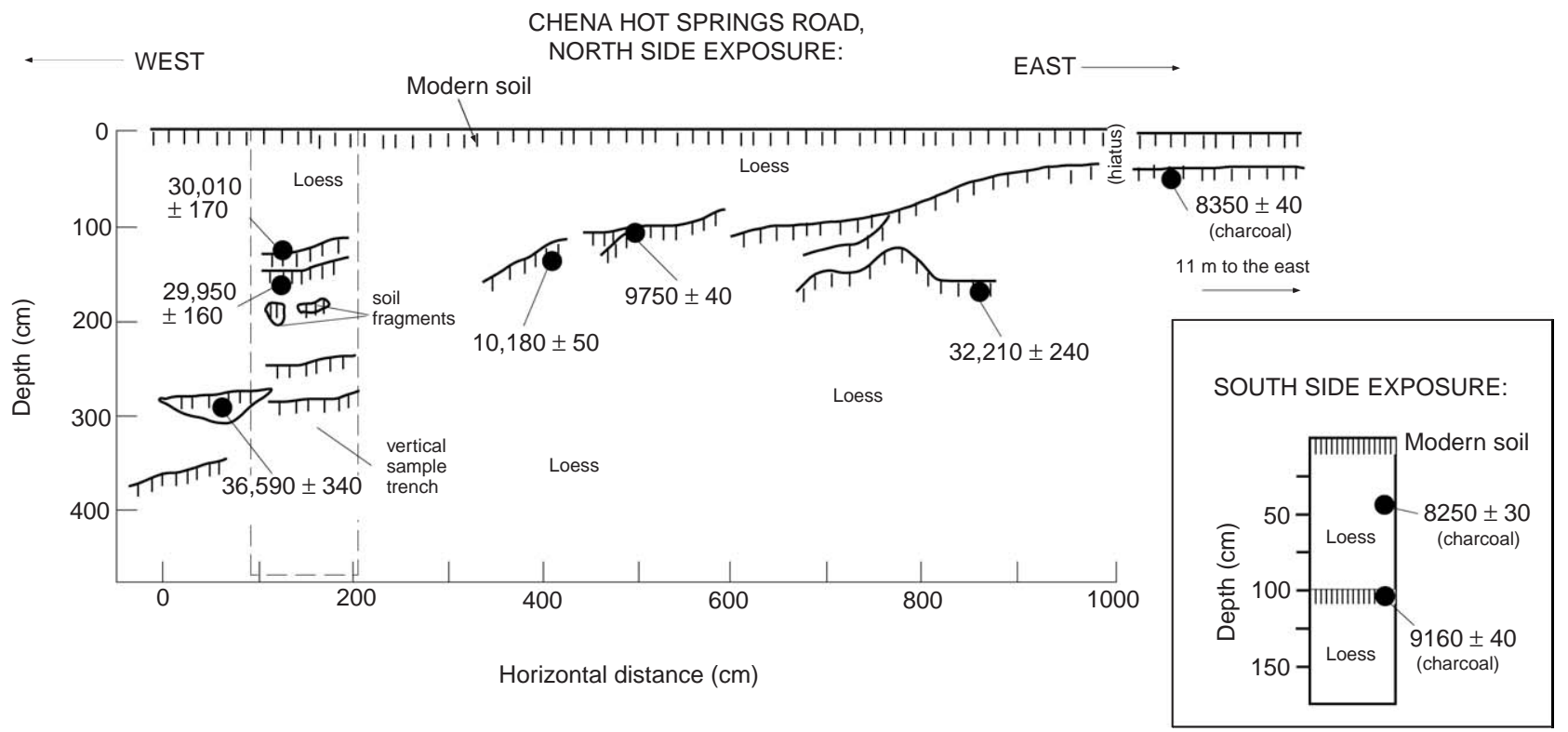

Fig. 12. Detail of the upper part of the Chena Hot Springs Road section showing soliflucted palaeosols and radiocarbon ages of soil organic matter and charcoal. All radiocarbon ages are humic acid extractions except where indicated.

(2001) conducted a similar study, including some samples from the Eva Creek section near Fairbanks. Their results show reasonable agreement of ages between humic acids $(<63 \mu \mathrm{m}$ fraction) and plant macrofossils, at least back to $\sim 30,000{ }^{14} \mathrm{C}$ yr $\mathrm{BP}$.
Because organic matter in soil A horizons may accumulate over thousands of years while still at the surface, perfect agreement between radiocarbon ages of macrofossils and humic acids is unlikely and should not be expected. 


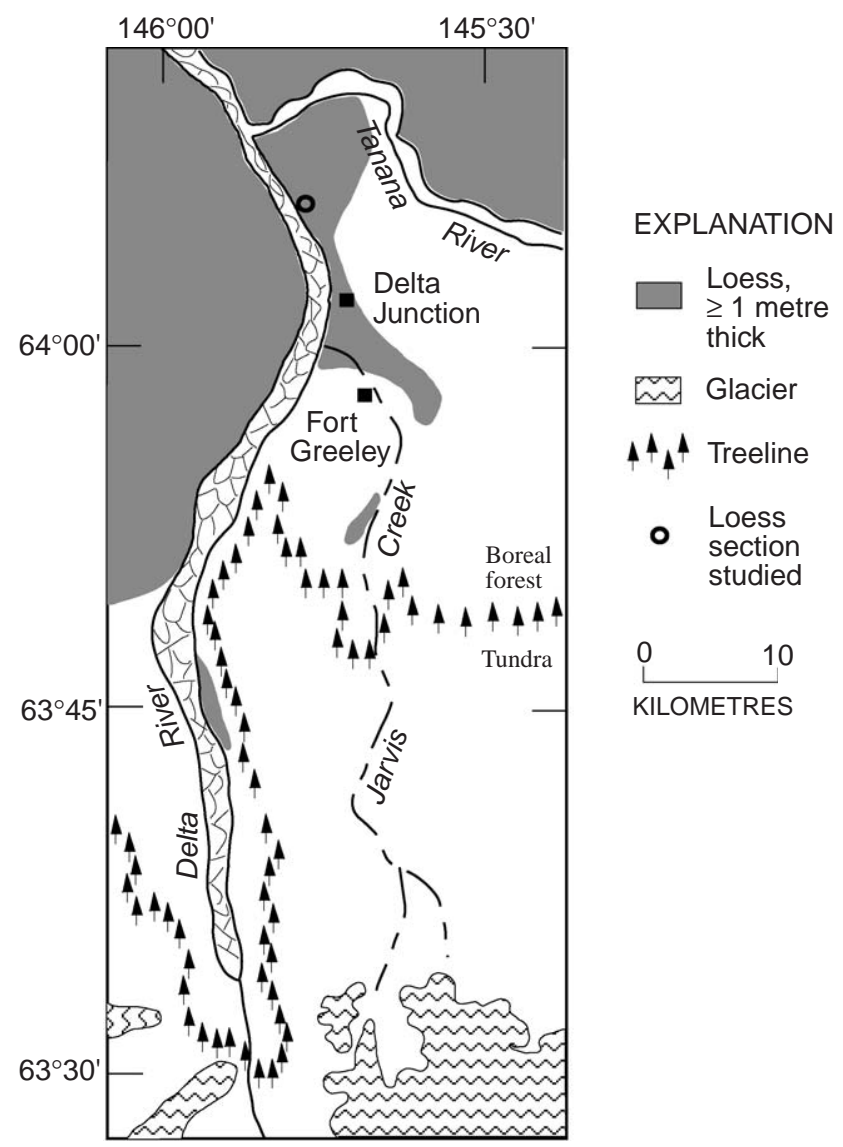

Fig. 13. Map showing the distribution of loess in the Delta Junction, Alaska area, position of treeline, and location of Holocene loess section studied. Loess distribution data from Lindholm et al. (1959) and Péwé and Holmes (1964); treeline mapped by the authors.

Sections at Chena Hot Springs Road (Figs. 11, 12) and a Holocene loess section near Delta Junction, Alaska (Fig. 14) have Holocene and late Pleistocene loess and palaeosols which contain both organic matter and plant macrofossils or charcoal that allow a test of the suitability of radiocarbon ages of humic acids (Table 2). At Delta Junction, radiocarbon ages of organic matter from late Holocene palaeosols agree well with bracketing or closely spaced radiocarbon ages of wood. At Chena Hot Springs Road, the uppermost palaeosol has humic acid age estimates of $9750 \pm 40$ and $10,180 \pm 50{ }^{14} \mathrm{C}$ yr BP; charcoal from this soil gave ages of $8350 \pm 40$ and $9160 \pm 40{ }^{14} \mathrm{C}$ yr BP, which agree broadly with the humic acid ages. Thus, these data suggest that radiocarbon ages of humic acids may be reliable for late Holocene, early Holocene and latest Pleistocene-aged organic matter. However, for some samples $\sim 30,000 \mathrm{yr}$ old and for those that are older, there are disagreements between humic acid and charcoal ages. For example, at Birch Hill, organic matter from a depth $3.82 \mathrm{~m}$ gave a humic acid age of $30,680 \pm 320{ }^{14} \mathrm{C}$ yr BP whereas charcoal from this depth gave an age of $41,600 \pm 1200{ }^{14} \mathrm{C}$ yr BP. A similar discrepancy is observed for humic acids and charcoal from a depth of $7.1 \mathrm{~m}$ at Chena Hot Springs Road $(39,380 \pm 490 \mathrm{yr}$ vs. $>55,900 \mathrm{yr})$. We conclude that humic acid ages less than $\sim 30,000{ }^{14} \mathrm{C}$ yr BP may be reliable, and that those older than $\sim 30,000 \mathrm{yr}$ are probably minima.

\section{3. ${ }^{10}$ Be age estimates of loess and palaeosols}

One method for estimating the cumulative duration of sedimentation and pedogenesis in a Quaternary stratigraphic section is inventory of ${ }^{10} \mathrm{Be}$. This isotope is cosmogenic, formed in the atmosphere by bombardment of $\mathrm{N}$ and $\mathrm{O}$ atoms with cosmic rays, which then form ${ }^{10} \mathrm{Be}$ by spallation. Because ${ }^{10} \mathrm{Be}$ is highly insoluble, after formation it is quickly sorbed on to adjacent solid particles and deposited on the earth's surface by washout or dry fallout. On a stable geomorphic surface, therefore, ${ }^{10} \mathrm{Be}$ will build up in a soil that has begun to form. ${ }^{10} \mathrm{Be}$ is a fairly long-lived isotope, at least on a late Quaternary timescale, with a half-life of $1.5 \mathrm{Ma}$ (Hofmann et al., 1987). Thus, inventory of the ${ }^{10} \mathrm{Be}$ abundances in a soil, combined with an estimate of the ${ }^{10} \mathrm{Be}$ production rate, horizon thicknesses and bulk densities will yield the amount of time of accumulation since stabilization of a surface after deposition. Thus, soils that have been at the surface longer and have better-developed horizons will also have higher concentrations of ${ }^{10} \mathrm{Be}$ (see examples in Curry and Pavich, 1996; Markewich et al., 1998).

Because there are few first-cycle sediments on the earth's surface, the probability is high that some of the measured ${ }^{10} \mathrm{Be}$ is inherited from a previous period of pedogenesis and surface accumulation. In China, for example, modern dust has ${ }^{10} \mathrm{Be}$ concentrations of $2.7 \times 10^{8}$ atoms $/ g$ (Shen et al., 1992). We estimated what this "background" ${ }^{10} \mathrm{Be}$ concentration might be for central Alaska by measuring the abundance of ${ }^{10} \mathrm{Be}$ in the radiocarbon-dated Holocene loess section near Delta Junction (Fig. 14). The radiocarbon ages, most of which are on wood fragments, show that deposition of this loess took place in the late Holocene. The section is located on the modern eastern cut bank of the Delta River and is thus very close to the immediate source of sediment (Fig. 13). The section is situated well upstream and upwind of Fairbanks-area loess deposits, but close to glaciers of the Alaska Range that probably produced (and probably still produce) much of the rock flour that is the source of loess. Thus, loess of the Delta Junction area has the greatest likelihood of being the first-cycle sediment of any deposit in the region. Even the poorly developed palaeosols found in the Delta Junction section, constrained to minimal periods of pedogenesis, show more ${ }^{10} \mathrm{Be}$ accumulation than the unaltered loess (Fig. 14). We used the lowest average values in the 


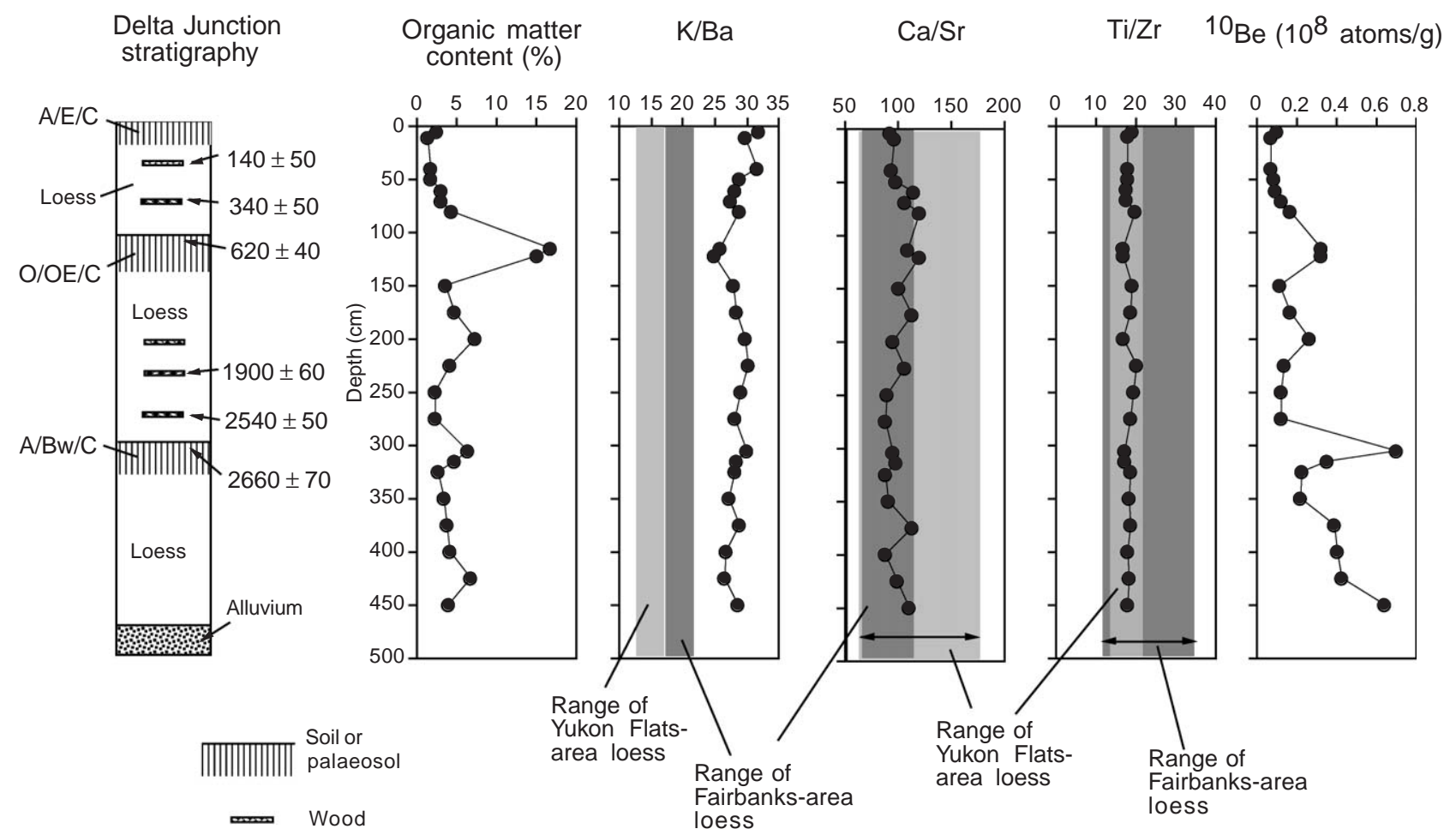

Fig. 14. Stratigraphy, radiocarbon ages, organic matter content, elemental ratios and concentrations of ${ }^{10} \mathrm{Be}$ in a Holocene loess section north of Delta Junction, Alaska. All radiocarbon ages are on wood except where arrow points to palaeosols. Ranges of elemental ratios in loess from other regions from Fig. 7.

unaltered loess samples of the upper Delta Junction section $\left(\sim 0.152 \times 10^{8}\right.$ atoms $/ \mathrm{g}$ of $\left.{ }^{10} \mathrm{Be}\right)$ as a correction for inherited ${ }^{10} \mathrm{Be}$ for all samples analyzed.

The global ${ }^{10} \mathrm{Be}$ production rate is not known with certainty and estimates vary by a factor of two. A "global average" deposition rate value of $1.2 \times 10^{6}$ atoms $/ \mathrm{cm}^{2} / \mathrm{yr}$ was presented by Monaghan et al. (1985/1986). Brown et al. (1989) reported midlatitude (wet) deposition rates of 1.5 to $1.6 \times 10^{6}$ atoms/ $\mathrm{cm}^{2} / \mathrm{yr}$. Following Pavich et al. (1985) and Curry and Pavich (1996), we use a value of $1.3 \times 10^{6}$ atoms $/ \mathrm{cm}^{2} / \mathrm{yr}$. Using the same methods, Markewich et al. (1998) showed that ${ }^{10} \mathrm{Be}$ inventory age estimates of loess and palaeosols in the mid-Mississippi River Valley showed good agreement with independently determined TL ages.

\subsection{Stratigraphy and ages of the Halfway House, Birch Hill, Chena Hot Springs Road and Gold Hill loess sections}

The Halfway House locality, west of Fairbanks and east of Nenana (Figs. 6-8), is an important loess section for interior Alaska because of its thickness, landscape position (an upland site), and the presence of at least two tephras. The section was first described by Westgate et al. (1983) who reported two tephras (including the Old Crow tephra) and two thin palaeosols in the section.
In subsequent published studies, more details have been added to the stratigraphy described for this section, although they are not consistent from study to study. Begét and Hawkins (1989) and Begét et al. (1990) identified four buried soils, including one just above the Old Crow tephra. Oches et al. (1998) also identified four buried soils, but the upper two are at different depths than those reported by Begét et al. (1990); Oches et al. (1998) also reported a soil developed around (i.e., above and below) the Old Crow tephra. Vlag et al. (1999) reported three buried soils at Halfway House, including one developed around the Old Crow tephra. Lagroix and Banerjee (2002), citing field observations by Oches, reported four palaeosols in the section. All of these workers presented bulk magnetic susceptibility measurements of soils and loess in the section, but no pedologic data. In addition, all investigators described the total loess section as $14-18 \mathrm{~m}$ thick, which we believe to be significant overestimates, based on careful measurements in cut steps with good vertical control. Preece et al. (1999) described only the lower part of the section, but their thickness measurements are in agreement with ours.

Our studies indicate that there are six and possibly seven buried soils in the Halfway House section, not including four thin soils found in a complex with the modern soil (Figs. 7, 8). All units that we identify as palaeosols have dark greyish brown (10YR 4/2, moist) 


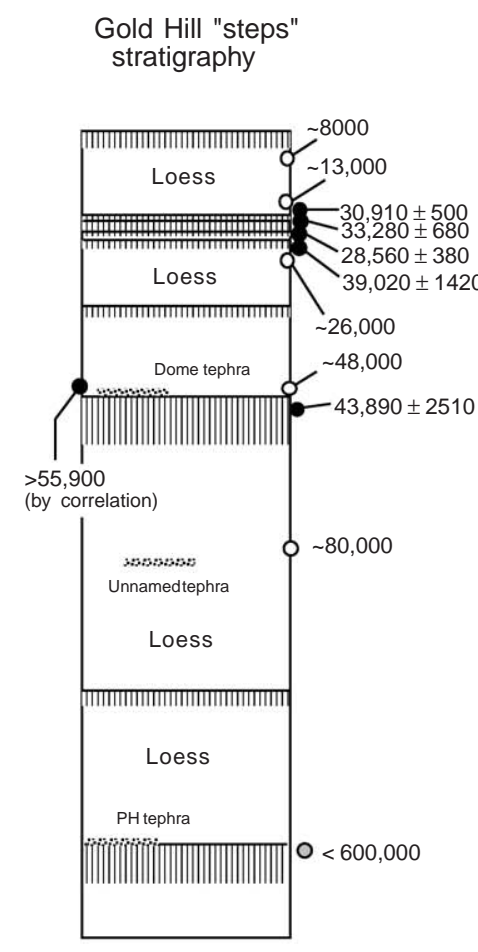

Organic matter content (\%)

$\mathrm{P}_{2} \mathrm{O}_{5}$ content (\%)

$\mathrm{Ti} / \mathrm{Zr}$
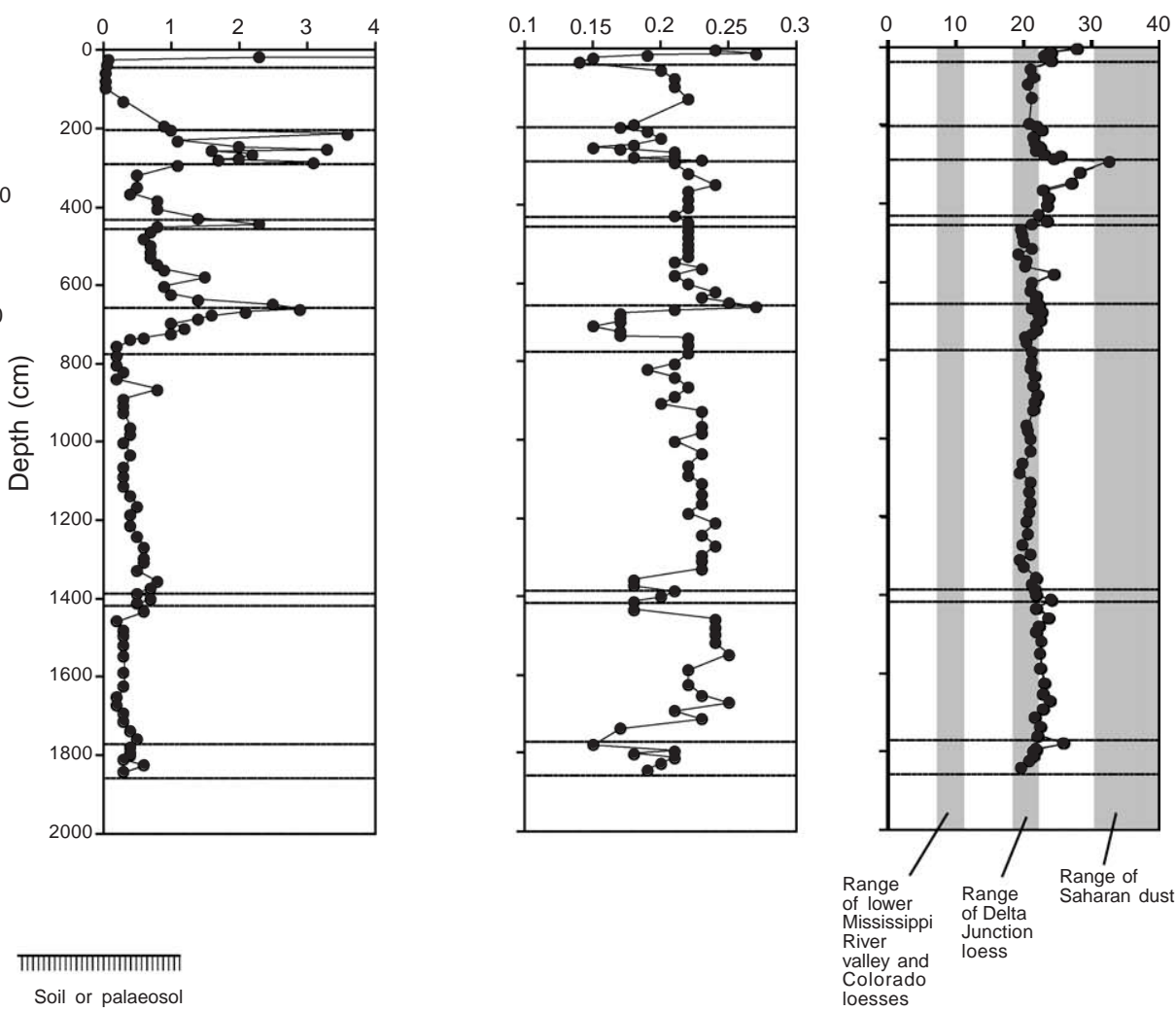

$$
\begin{aligned}
& { }^{14} \mathrm{C} \text { age estimate } \\
& \mathrm{O}^{10} \mathrm{Be} \text { age estimate } \\
& \mathrm{O} \text { Fission track } \\
& \text { age estimate }
\end{aligned}
$$

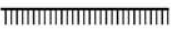

Soil or palaeosol

Fig. 15. Loess stratigraphy, radiocarbon ages, and selected ${ }^{10} \mathrm{Be}$ age estimates at the Gold Hill "steps" section. Also shown for comparison are plots of organic matter and $\mathrm{P}_{2} \mathrm{O}_{5}$ concentrations, and $\mathrm{Ti} / \mathrm{Zr}$ values as a function of depth in this section. All radiocarbon ages are humic acid extractions. Fission track age of $\mathrm{PH}$ tephra is a maximum-limiting age based on direct dating of an older, dated tephra that underlies the PH tephra elsewhere in the Gold Hill area (see Preece et al., 1999). Sources of Ti/Zr ranges for other aeolian sediments as in Fig. 7.

A horizons. Where $\mathrm{Bw}$ horizons are present, they have strong brown ( $7.5 \mathrm{YR} 5 / 6$ or $5 / 8$, moist) colours, sometimes with yellowish red (5YR 5/8, moist) oxidation streaks, even though they cannot be differentiated in the field on the basis of texture or structure. All palaeosols we identified at Halfway House have high organic matter contents, $\mathrm{P}_{2} \mathrm{O}_{5}$ curves that match modern soils, and large amounts of fine silt, clay and $\mathrm{Al}_{2} \mathrm{O}_{3}$. Three thin, poorly developed palaeosols are present between the residuum from schist at the base of the section and the Old Crow tephra, only one of which is clearly identifiable from the $\mathrm{P}_{2} \mathrm{O}_{5}$ trends. However, we see no field evidence for a well-developed soil immediately above or below the Old Crow tephra. At approximately $800 \mathrm{~cm}$ depth, just above the Old Crow tephra, there is a depletion in $\mathrm{P}_{2} \mathrm{O}_{5}$, an increase in fine silt content, and a slight increase in clay content, but no significant change in colour, structure or organic matter content. These observations suggest the possible presence of a weakly developed but truncated palaeosol whose A horizon has been eroded. A thin, but well- developed soil occurs at a depth of $\sim 620-640 \mathrm{~cm}$. This soil has a $\mathrm{Bw}$ horizon, clearly expressed in its colour, and thin clay lamellae similar to those seen in modern interior Alaska loess-derived soils. Organic matter, clay, fine silt and $\mathrm{Al}_{2} \mathrm{O}_{3}$ contents are very high in this thin soil. Finally, at a depth of $380-480 \mathrm{~cm}$, we observed two palaeosols, the oldest of which has a well-expressed Bw horizon. Deeper lateral excavations indicate that this soil may merge laterally into an ice wedge cast. Small, discontinuous blebs of tephra were found in the lower part of this soil and geochemical data indicate a correlation with the Halfway House tephra (Table 2; cf. Preece et al., 1999). This palaeosol couplet was reported by Begét et al. (1990) but not described by Oches et al. (1998), Vlag et al. (1999) or Lagroix and Banerjee (2002), although it is apparent in their data as a magnetic susceptibility low at $\sim 400 \mathrm{~cm}$ depth.

Radiocarbon ages of humic acids from the Halfway House palaeosols give only a partial chronology. The thin, but well developed palaeosol at $620-640 \mathrm{~cm}$ depth has an apparent finite age of $42,160 \pm 2030{ }^{14} \mathrm{C}$ yr BP, 

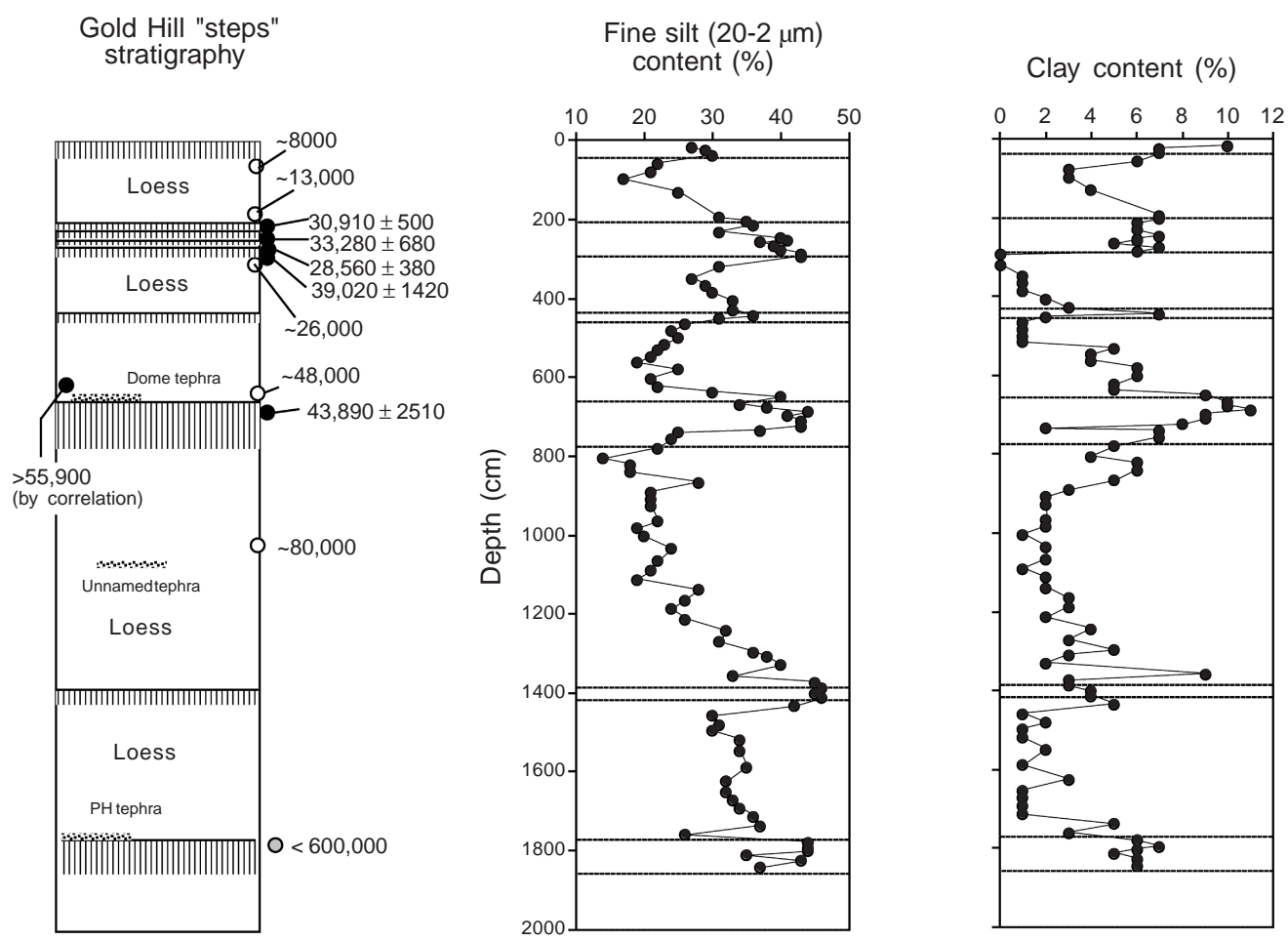
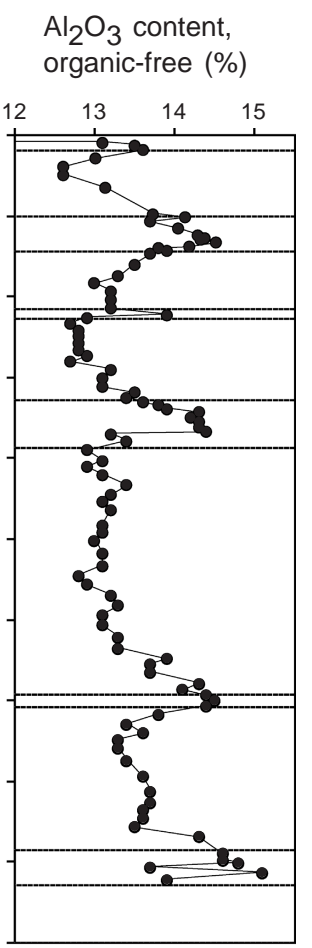

$$
\begin{array}{|l|l|}
\hline{ }^{14} \mathrm{C} \text { age estimate } & \text { TाTाTाTाTाTाTाTाTाTा } \\
\mathrm{O}^{10} \mathrm{Be} \text { age estimate } & \text { Soil or palaeosol } \\
\hline \begin{array}{l}
\text { Fission track } \\
\text { age estimate }
\end{array} & \\
\hline
\end{array}
$$

Fig. 16. Loess stratigraphy, radiocarbon ages, and selected ${ }^{10}$ Be age estimates at the Gold Hill "steps" section. Also shown for comparison are plots of fine silt, clay, and $\mathrm{Al}_{2} \mathrm{O}_{3}$ concentrations as a function of depth in this section.

but we interpret this to be a strictly minimum age. Such an interpretation agrees with a ${ }^{14} \mathrm{C}$ age of $>41,000 \mathrm{yr}$ BP reported by Oches et al. (1998) for a palaeosol at or near this stratigraphic position. The palaeosol couplet at $380-480 \mathrm{~cm}$ has humic acid ${ }^{14} \mathrm{C}$ ages of $32,530 \pm 620$ (lower) and 30,580 $\pm 480 \mathrm{yr}$ (upper), which is consistent with their stratigraphic positions and the minimal degree of development of the upper palaeosol. Based on the comparison of $\sim 30,000 \mathrm{yr}$ old humic acid-wood sample pairs from Eva Creek (McGeehin et al., 2001), the possibility exists that the radiocarbon ages of these palaeosols are close to the true ages; given the disagreement between humic acid and charcoal ages at Birch Hill, however, they could also be minimum ages.

An independent method of age estimates for Halfway House comes from ${ }^{10} \mathrm{Be}$ measurements of the palaeosols and loess. Concentrations of ${ }^{10} \mathrm{Be}$ are consistently higher in the palaeosols than in the loess, indicating longer periods of subaerial exposure and ${ }^{10} \mathrm{Be}$ accumulation from the atmosphere (Table 3). At Halfway House, ${ }^{10} \mathrm{Be}$ concentrations in palaeosols range from about 1.3-
$3.0 \times 10^{8}$ atoms $/ \mathrm{g}$, which are on average much lower than midcontinent Sangamon paleosols developed in either till or loess (Curry and Pavich, 1996), loess or palaeosols developed in loess in New Zealand (Graham et al., 2001) and even lower than in loess or palaeosols developed in loess in China (Gu et al., 1997). However, concentrations of ${ }^{10} \mathrm{Be}$ in relatively unaltered loess at Halfway House are still significantly higher than probable first-cycle late Holocene loess from Delta Junction (Fig. 14). This observation suggests that sedimentation at Halfway House, even in those zones between palaeosols, was relatively slow, such that significant ${ }^{10} \mathrm{Be}$ accumulation could take place. An alternative explanation is that much of the loess was derived from reworked sediments that had experienced previous periods of subaerial exposure. Using the assumptions described earlier regarding ${ }^{10} \mathrm{Be}$ production, accumulation and inheritance we calculated ages for the sediments at Halfway House (Table 3 and Figs. 7, 8). Results are in reasonable agreement with the radiocarbon chronology for the upper half of the section. The uppermost loess unit, below the modern 
soil and above the palaeosol couplet at $380-480 \mathrm{~cm}$, could have been deposited between $\sim 8000$ and 17,000 cal yr BP and the palaeosol couplet could have developed between $\sim 17,000$ and $30,000 \mathrm{yr}$ BP. The radiocarbon ages of the palaeosol couplet, converted to calendar yr ages using the chronology presented by Voelker et al. (2000), are $~ 35,780$ (lower) and $\sim 33,960$ (upper) yr BP, which are somewhat older than but broadly consistent with the ${ }^{10} \mathrm{Be}$ age estimates. Bracketing ${ }^{10} \mathrm{Be}$ age estimates of $\sim 39,000 \mathrm{yr}$ (above) and $\sim 42,000$ yr (below) around the thin palaeosol at $\sim 620$ $640 \mathrm{~cm}$ are also broadly consistent with the radiocarbon age of $42,160 \pm 2030 \mathrm{yr}$ BP. A calendar-year age for this palaeosol is $\sim 43,000 \mathrm{yr} \mathrm{BP}$, if we assume that this is a finite age. In the lowest part of the section, however, a significant discrepancy occurs between the ${ }^{10} \mathrm{Be}$ age estimates and the estimated age of the Old Crow tephra. Just above the Old Crow tephra, the ${ }^{10} \mathrm{Be}$ inventory indicates an age of $\sim 57,000 \mathrm{yr}$, which is clearly too young based on the fission-track and TL age estimates of $\sim 120,000$ to $\sim 160,000 \mathrm{yr}$ for the Old Crow tephra.

At least two explanations are possible for the discrepancies between the ${ }^{10} \mathrm{Be}$ age estimates and independent age estimates for loess and palaeosols at Halfway House, and they are not mutually exclusive. One possibility is that our assumed production rate for ${ }^{10} \mathrm{Be}$ in this region (taken from the "global averages" given by (Monaghan et al., 1985/1986 and Brown et al., 1989) is too high. Graham et al. (2001) point out that ${ }^{10} \mathrm{Be}$ fluxes at present are lower in the Dry Valleys of Antarctica where precipitation is very low and also during drier glacial periods in New Zealand. Given the relatively low present precipitation $(276 \mathrm{~mm} / \mathrm{yr})$ in the Fairbanks area today (see Muhs et al., 2000a) and the probability that precipitation was even lower during glacial periods (Ager and Brubaker, 1985 and Anderson and Brubaker, 1994), it is certainly possible that our use of the global average production rate is an overestimate. Using a production rate $25 \%$ lower than the global average would bring the ${ }^{10} \mathrm{Be}$ age estimates of the palaeosols at $\sim 380-480 \mathrm{~cm}$ and $\sim 620-640 \mathrm{~cm}$ into much better agreement with their radiocarbon ages. Nevertheless, the estimated cumulative age of the loess interval just above the Old Crow tephra would still be only $\sim 74,000 \mathrm{yr}$ BP, clearly too young given the age estimates of this tephra. We conclude from these data that the second explanation must also apply, namely that at least one unconformity must exist within the section. If we assume that our production rate estimates are too low, then in the simplest case (i.e., a single unconformity), sediment must have been removed somewhere between the depths of the thin palaeosol at $\sim 620-640 \mathrm{~cm}$ and the Old Crow tephra. In the lower part of the Eva Creek section near Fairbanks, the Dome tephra occurs less than $200 \mathrm{~cm}$ above the Old Crow tephra (see Muhs et al., 2001a). In addition, a well- developed palaeosol, thought to date from the last interglacial period, is found around and immediately below the Old Crow tephra at Eva Creek. At Halfway House, we found neither the Dome tephra nor a palaeosol comparable in development to that at Eva Creek. We conclude, therefore, that part of the discrepancy between the ${ }^{10} \mathrm{Be}$ age estimates and the fission track and TL ages of the Old Crow tephra are due to at least one unconformity at Halfway House. However, the ${ }^{10} \mathrm{Be}$ age estimates for the upper part of the section are in broad agreement with the radiocarbon chronology using the global average ${ }^{10} \mathrm{Be}$ production rate and in excellent agreement if we use a rate $25 \%$ lower than the global average.

The loess section we studied at Birch Hill (Figs. 9, 10) has, to our knowledge, never been reported before, although Péwé (1955) did study other exposures in the Birch Hill area. The upper $500 \mathrm{~cm}$ or so are exposed in a road cut and another $800 \mathrm{~cm}$ were recovered by bucketaugering. Sediment mixing by the bucket-augering process may well have precluded the possibility of observing any tephras in this section. Apart from an apparent lack of tephras, the section at Birch Hill has many characteristics similar to that at Halfway House. A palaeosol, apparent even in bucket-auger samples, occurs just below $1200 \mathrm{~cm}$ and a thicker, better developed one occurs around $800 \mathrm{~cm}$. The uppermost of these two palaeosols is apparent also in the organic matter and $\mathrm{P}_{2} \mathrm{O}_{5}$ contents, but the lowermost soil is apparent only in the plot of $\mathrm{P}_{2} \mathrm{O}_{5}$ concentrations. Higher in the section, three welded palaeosols occur between $\sim 300$ and $400 \mathrm{~cm}$ and are well exposed in the road cut. Their A horizon hues are $10 \mathrm{YR}$ or $7.5 \mathrm{YR}$, resembling the uppermost buried soils at Halfway House. This welded soil complex shows a very definite peak in organic matter and $\mathrm{P}_{2} \mathrm{O}_{5}$ contents.

As with the section at Halfway House, the Birch Hill section shows fine silt, clay and $\mathrm{Al}_{2} \mathrm{O}_{3}$ maxima where palaeosols occur (Fig. 10). With the exception of clay content in the middle part of the section, fine silt, clay and $\mathrm{Al}_{2} \mathrm{O}_{3}$ contents in unaltered loess reach their maximum values immediately above each palaeosol, with minima immediately below the next-youngest palaeosol. Because this pattern also occurs at the Halfway House section, our interpretation is that this is a general trend in the stratigraphic record of upland loess in this area.

We have fewer radiocarbon ages and no ${ }^{10} \mathrm{Be}$ data for the Birch Hill section. Nevertheless, what data we do have indicate that the lowermost palaeosol in the complex of three welded soils could be as old as $41,600 \pm 1200{ }^{14} \mathrm{C}$ yr BP, based on charcoal fragments found in this soil. The younger two palaeosols in this complex have only humic acid extractions available for dating, but provide approximate ages of $\sim 27,000$ and $\sim 34,000{ }^{14} \mathrm{C}$ yr BP. The palaeosol that occurs at about 
$800 \mathrm{~cm}$ has an apparent humic acid age of $38,530 \pm 810$ ${ }^{14} \mathrm{C}$ yr BP, which is clearly a minimum-limiting age.

A newly exposed road cut on Chena Hot Springs Road, immediately east of Fairbanks and not far from Birch Hill, has an excellent, laterally extensive exposure of loess and palaeosols, and reveals many of the complicating aspects of upland loess stratigraphy (Figs. $11,12)$. We know of no previous studies of this section or any near it. Loess here is draped over a convex upland bedrock knob and thickens away from this topographic high on either side. At least 11 palaeosols occur in the section. Ten of these soils are exposed in the main vertical trench studied; all show organic matter and $\mathrm{Al}_{2} \mathrm{O}_{3}$ maxima and most show the "high-low-high" trend in $\mathrm{P}_{2} \mathrm{O}_{5}$ depth functions. A late Pleistocene-early Holocene soil is also present east of the main trench on the north side of the road, and is exposed on the south side of the road as well.

Lateral exposure of the loess shows that many palaeosols are discontinuous and this required an extensive suite of radiocarbon ages, even for lateral correlation over short distances. Some palaeosols are welded in a vertical sense, others terminate abruptly in a lateral sense and still others consist of irregular fragments or lens-shaped structures (Figs. 11, 12). The exposure on the south side of the road shows only the upper part of the stratigraphy, but Holocene loess is present in the upper $100 \mathrm{~cm}$ or so, based on two radiocarbon ages of $8250 \pm 30 \mathrm{yr}$ and $9160 \pm 40 \mathrm{yr}$ on charcoal. On the north side of the road, the Holocene loess is also exposed, based on charcoal and humic acid ages of $8350 \pm 40 \mathrm{yr}, 9750 \pm 40 \mathrm{yr}$, and $10,180 \pm 50 \mathrm{yr}$ from the same palaeosol that yielded the $9160 \pm 40 \mathrm{yr}$ age from the south side exposure. However, the $\sim 8000$ 10,000 -yr-old palaeosol is fragmented on the north side exposure and simply terminates to the west. Just beyond its westernmost exposure, two welded palaeosols at similar depths gave humic acid radiocarbon ages of $30,010 \pm 170$ and $29,950 \pm 160{ }^{14} \mathrm{C}$ yr BP. These ages are similar to the age $\left(32,210 \pm 240{ }^{14} \mathrm{C}\right.$ yr BP $)$ of a palaeosol that occurs below the 8000-10,000-yr-old palaeosol just a few metres to the east (Fig. 12). We interpret these observations to mean that these soils have probably experienced a significant amount of disturbance by erosion and downslope movement, with the result that the stratigraphy is exceedingly complex.

With one important exception, the only materials available for dating from older palaeosols in the section are humic acid extractions. These palaeosols, taken in a trench in the westernmost part of the exposure, give ages (upper to lower) of $36,590 \pm 340{ }^{14} \mathrm{C} \mathrm{yr} \mathrm{BP}, 37,050 \pm 390$ ${ }^{14} \mathrm{C}$ yr BP, and $39,380 \pm 490{ }^{14} \mathrm{C}$ yr BP. Although there are no stratigraphic reversals in this suite of radiocarbon analyses, we interpret all of these to be minimum ages. Part of our rationale for this interpretation is that the palaeosol at $\sim 700 \mathrm{~cm}$ (which gave a humic acid age of
$39,380 \pm 490{ }^{14} \mathrm{C}$ yr BP) also contained charcoal which gave an age of $>55,900{ }^{14} \mathrm{C}$ yr BP. This radiocarbon age is important not only for showing the antiquity of the palaeosol at $\sim 700 \mathrm{~cm}$, but also for providing a minimum-limiting age for the Dome tephra, which occurs immediately below this palaeosol.

The Gold Hill loess section, near Fairbanks, has been studied by many investigators, including Westgate et al. (1990), Begét (1990), Sher et al. (1997), Preece et al. (1999) and Vlag et al. (1999). At its most complete exposures, the section is more than $30 \mathrm{~m}$ thick and is underlain by gravels of probable Tertiary age (Preece et al., 1999). Palaeomagnetic measurements and fission track ages of tephras show that the oldest loess units at Gold Hill may be $\sim 3 \mathrm{Ma}$ (Westgate et al., 1990). The Gold Hill locality is situated within what Péwé et al. (1966) mapped as "perennially frozen silt, undifferentiated" and what we refer to as "valley loess and reworked loess." It is not the topographically highest portion of the local landscape, which is probably why Péwé et al. (1966) mapped it in what we would call the "valley loess" facies. Nevertheless, it is much higher topographically than the adjacent valley bottom and can be considered to be a well-drained, upland loess locality. We studied a $20 \mathrm{~m}$-thick section just to the east of the thickest sections exposed, where a series of steps have been cut into the loess and vertical measurement control is excellent. The same section has also been studied by Begét (1990) and Vlag et al. (1999).

We found what we interpret to be at least eight palaeosols in the 20-m thick Gold Hill section (Figs. 15, 16). The lowermost soil, at $\sim 1800 \mathrm{~cm}$ depth, is actually a pedocomplex that may contain as many as three welded soils. Above this pedocomplex, a thin but recognizable soil with only an A horizon occurs at $\sim 1400 \mathrm{~cm}$ depth. Between $\sim 665$ and $760 \mathrm{~cm}$ depth there is a very well developed, welded palaeosol couplet; the lower soil has both a thick A horizon and a thick Bw horizon. Blebs of the Dome tephra (Table 2) occur in the upper part of the upper palaeosol of this couplet. A thin soil with only an A horizon occurs at $\sim 445 \mathrm{~cm}$, but between depths of $\sim 210$ and $\sim 290 \mathrm{~cm}$, there is a complex package of four welded palaeosols (Table 4).

All buried soils at Gold Hill have very distinctive horizon colours. Buried A horizons have low values and chromas and, in addition, have a slightly reddish hue (7.5YR 3/2). The palaeosol between 665 and $760 \mathrm{~cm}$ depth has a $\mathrm{Bw}$ horizon with yellowish brown colours (10YR 5/8, moist). The three welded soils at $\sim 1800 \mathrm{~cm}$ depth have brown (7.5YR 4/4, moist), strong brown (7.5YR 4/6, moist) or olive yellow (2.5Y 6/6, moist) colours.

Organic matter, $\mathrm{P}_{2} \mathrm{O}_{5}$ and particle size data support the field identification of palaeosols at Gold Hill. Organic matter contents show high values in the palaeosols and low values in the loess down to a depth 
of $\sim 1400 \mathrm{~cm}$. Palaeosols at or below a depth of $\sim 1400 \mathrm{~cm}$ are not apparent from the organic matter curve (Fig. 15). However, concentrations of $\mathrm{P}_{2} \mathrm{O}_{5}$ mark the occurrence of palaeosols clearly, even in the oldest parts of the section. All palaeosols identified in the field show the "high-low-high" trend in $\mathrm{P}_{2} \mathrm{O}_{5}$ that is expected with uneroded soils. Because of the possibility that sediments at Gold Hill could consist in part of colluvially reworked, rather than direct (air-fall) loess (Péwé et al., 1966), we expected that particle size data might show a wider range of variability in both the loess and the palaeosols. However, the range in fine silt and clay content in loess at Gold Hill is very similar to that observed at Halfway House and Birch Hill (Fig. 16). Furthermore, as in the other sections, the palaeosols at Gold Hill consistently show higher fine silt and clay contents than the loess. As we observed at Halfway House and Birch Hill, fine silt, clay and $\mathrm{Al}_{2} \mathrm{O}_{3}$ contents in unaltered loess are highest immediately above each palaeosol and decrease steadily to minimum values immediately below the next-youngest palaeosol.

Radiocarbon, ${ }^{10} \mathrm{Be}$ and tephra age estimates show that the Gold Hill section, like other loess sections, has probably experienced removal of at least part of its record. The four palaeosols between $\sim 210$ and $290 \mathrm{~cm}$ depths gave humic acid radiocarbon ages ranging from $28,560 \pm 380$ to $39,020 \pm 1420{ }^{14} \mathrm{C}$ yr BP (Fig. 15). As with Birch Hill, it is quite possible that many of these are minimum ages. The well-developed palaeosol between 665 and $760 \mathrm{~cm}$ has a humic acid radiocarbon age of $43,890 \pm 2510{ }^{14} \mathrm{C}$ yr BP, which is certainly a minimum age, because it contains the Dome tephra in its upper part, dated to $>55,900{ }^{14} \mathrm{C}$ yr $\mathrm{BP}$ at Birch Hill. ${ }^{10} \mathrm{Be}$ ages in the upper $400 \mathrm{~cm}$ of the section are significantly younger than radiocarbon ages of the palaeosols. As discussed above, these radiocarbon ages may themselves be minimum ages. If so, the ${ }^{10} \mathrm{Be}$ ages indicate, therefore, that much of the section that would have recorded events between $\sim 13,000$ and $\sim 35,000$ cal yr BP may be missing. Much of the older loess record may be missing as well. For example, the presence of the Dome tephra indicates that part of the record around the time of the last interglacial period is present, when compared to the stratigraphy of the Eva Creek section (Muhs et al., 2001a). However, not all of the record is present at Gold Hill because the Old Crow tephra is missing. Furthermore, the ${ }^{10} \mathrm{Be}$ age estimate of $\sim 48,000 \mathrm{cal}$ yr BP for the Dome tephra is too young, compared to its radiocarbon age of $>55,900 \mathrm{yr} \mathrm{BP}$.

\subsection{Changes in loess sources over time}

Use of $\mathrm{Ti} / \mathrm{Zr}$ values within loess sections allows evaluation of the possibility that loess sources may have changed over time. Given the diversity of lithologies in the glaciated mountain ranges of Alaska, and even within the Alaska Range, it is possible that over time, and particularly over glacial-interglacial cycles with different palaeowinds, loess sources could have changed. We used $\mathrm{Ti} / \mathrm{Zr}$ values as a geochemical signature in the sections studied. Both $\mathrm{Ti}$ and $\mathrm{Zr}$ are chemically immobile in most near-surface environments and thus are unlikely to be lost as a result of diagenesis, weathering and soil formation. We compare $\mathrm{Ti} / \mathrm{Zr}$ values in Alaskan loess with $\mathrm{Ti} / \mathrm{Zr}$ values from what are thought to be single- and multiple-source loess deposits elsewhere in North America.

Central Alaskan loess has $\mathrm{Ti} / \mathrm{Zr}$ values that are much higher than loess elsewhere in North America. Most Fairbanks-area loess deposits have $\mathrm{Ti} / \mathrm{Zr}$ values around 20-25 and an extreme range of about 13-35 (Figs. 7, 9, $11,14,15)$. Loess deposits in both glaciated and unglaciated parts of midcontinental North America have lower $\mathrm{Ti} / \mathrm{Zr}$ values. In the lower Mississippi River Valley, loess deposits are restricted to a narrow zone parallel to, and to the east of the river valley itself and there are no known or likely sources to the west of this major source. Thus, the probability is very high that loess in this region is derived dominantly, if not solely, from the Mississippi River Valley. Based on 24 samples of leached but otherwise unaltered loess from 10 localities over a 400-km north-south distance (from northern Louisiana to northern Mississippi), Mississippi River-derived loess of last-glacial age has $\mathrm{Ti} / \mathrm{Zr}$ values with a narrow range of 8-11 (Pye and Johnson, 1988; Muhs et al., 2001b). Eastern Colorado loess is derived from both Precambrian crystalline rocks and Tertiary volcaniclastic siltstone (Aleinikoff et al., 1999), yet has $\mathrm{Ti} / \mathrm{Zr}$ values with only a slightly broader range of 6-12 (Muhs et al., 1999a, b; Muhs and Zárate, 2000). Saharan dust, and soils thought to have developed from Saharan dust (see Muhs et al., 1990 and references therein) have $\mathrm{Ti} / \mathrm{Zr}$ values ranging from 32 to 40 . Given the narrow ranges of midcontinental North American loess deposits from what are thought to be single (Mississippi Valley) or multiple (eastern Colorado) sources and Saharan dust, the much broader range of values in Alaskan loess (13-25) may reflect a relatively wide range of source lithologies.

It is interesting to note that in many parts of most sections, $\mathrm{Ti} / \mathrm{Zr}$ values in unaltered loess are similar to those in superjacent or subjacent palaeosols. This observation can be interpreted to mean that loess sources may not have changed much between glacial and either interglacial or interstadial periods. In addition, it is noteworthy that $\mathrm{Ti} / \mathrm{Zr}$ values in loess at both upland summit settings (e.g., Halfway House) and a midslope setting (Gold Hill) are not significantly different. This observation suggests that loess at Gold Hill consists largely of either direct airfall loess and/or colluvially reworked loess that has little other sediment of different sources (e.g., local bedrock-derived 
materials) mixed with it. It is likely that $\mathrm{Pb}$-isotopic studies of K-feldspars in Alaskan loess could yield more definitive information about loess sources, using the approach of Aleinikoff et al. (1998, 1999). This approach has a high probability of success, given that source terranes in the region have distinctive $\mathrm{Pb}$-isotopic signatures in K-feldspar (Aleinikoff et al., 1987).

\subsection{Mass accumulation rates of Alaskan loess}

Mass accumulation rates (MARs) were calculated for Alaskan loess sections described in this paper and for published sections described elsewhere (Table 5). MAR calculations are useful for loess sections because dust fluxes on land can then be compared directly with dust fluxes to the oceans and to glacial ice. In making these calculations, we used an approach similar to that utilized for loess of the midcontinent of North America reported by Bettis et al. (this volume). For the Halfway House and Gold Hill sections, we used measured or interpolated bulk densities given in Tables 3 and 4 . Elsewhere, we assumed a bulk density of 1.45 for loess at all localities, except for lacustrine sediments from St. Michael Island, where we assumed a bulk density of 0.63. Where radiocarbon ages were available, we computed MARs using calendar-year conversions from Stuiver et al. (1998) for samples less than $\sim 20,000{ }^{14} \mathrm{C}$ $\mathrm{yr} \mathrm{BP}$, and using the closest calendar-year ages available for samples older than $\sim 20,000{ }^{14} \mathrm{C}$ yr BP from Voelker et al. (2000).

Results indicate a wide variety of Holocene MARs across the region, spanning more than two orders of magnitude (Table 5). The large difference between the two extreme localities, Sagwon $\left(\sim 3 \mathrm{~g} / \mathrm{m}^{2} / \mathrm{yr}\right)$ and Delta Junction $\left(\sim 1540 \mathrm{~g} / \mathrm{m}^{2} / \mathrm{yr}\right)$, might be explained by a combination of both a higher silt production rate near active glaciers and a favorable boreal forest environment for loess accumulation at Delta Junction. Other localities under boreal forest, such as Fairbanks, the Matanuska Valley, and Kenai have relatively high Holocene rates of $\sim 300-400 \mathrm{~g} / \mathrm{m}^{2} / \mathrm{yr}$, whereas tundra localities, such as the Brooks Range, Seward Peninsula and Ahklun Mountains, all have Holocene loess accumulation rates of less than $100 \mathrm{~g} / \mathrm{m}^{2} / \mathrm{yr}$.

There are few localities where we could confidently generate full-glacial MARs, and we are reluctant to generalize about the resultant values (Table 5). For example, Epiguruk, with a relatively high accumulation rate $\left(\sim 500 \mathrm{~g} / \mathrm{m}^{2} / \mathrm{yr}\right)$, is immediately adjacent to its presumed glaciofluvial source, and therefore may not be representative of a large, regional-scale loess body. Another locality, one that probably is representative of a larger region (Egg Lake on the Seward Peninsula), also has a fairly high full-glacial MAR $\left(668 \mathrm{~g} / \mathrm{m}^{2} / \mathrm{yr}\right)$. However, the stratigraphic data available for Egg Lake and localities around it are few and, as a result, we could calculate a MAR for only a short interval (less than $2000 \mathrm{yr}$ ) within the last glacial period. Thus, the high rate of loess fall calculated for this short period may not be representative of the entire full-glacial period. Other problems with full-glacial MARs are related to geomorphic setting or chronologic control. At the Chatanika River cut north of Fairbanks, the Fox permafrost tunnel near Fairbanks, and at Dawson in Yukon Territory, loess that could date to the last glacial period is found in a valley setting, so we have no indication of how much loess was direct airfall and how much was reworked from adjacent hillslopes. Also at Dawson, and on St. Michael Island and the Kvichak Peninsula, age control at the younger end falls into the Holocene, so our computed MARs actually span part of full-glacial time and part of the early Holocene. Recent geochemical studies by Muhs et al. (2000b) show that the sediments in lakes on St. Michael Island are distinct from the local bedrock and are almost certainly aeolian, given the low topography of the island. Current work on Zagoskin Lake on St. Michael Island may well yield better chronological control that will allow us to compute more realistic MARs for western Alaska.

\section{Discussion}

\subsection{Stratigraphic record of central Alaskan loess}

Field and laboratory data support the conclusion that palaeosols are an important part of the loess stratigraphic record in central Alaska. Field morphology, organic matter content and $\mathrm{P}_{2} \mathrm{O}_{5}$ contents show that palaeosols are present in all loess sections studied. A major conclusion from these observations is that loess sedimentation was not continuous, and at times was sufficiently slow for pedogenesis to keep ahead of loess accretion. Particle size data, combined with concentrations of $\mathrm{Al}_{2} \mathrm{O}_{3}$, also support the field identification of buried soils at Halfway House, Gold Hill and Birch Hill and provide insight into the nature of loess sedimentation. Clay content is consistently higher in what are identified as buried soils, lying in the range $6-13 \%$. In contrast, unaltered loess has clay contents that are always less than $5 \%$ and generally $3 \%$ or less. Previous loess/palaeosol studies have shown that aluminosilicate clay content is linearly correlated with $\mathrm{Al}_{2} \mathrm{O}_{3}$ content (Markewich et al., 1998; Muhs and Bettis, 2000). In central Alaskan loess, this is also the case, as $\mathrm{Al}_{2} \mathrm{O}_{3}$ contents show fluctuations that are in phase with clay content and are highest in what are identified as palaeosols.

Although clay content is highest in what we have identified as buried soils, it does not appear that the higher clay contents are due to pedogenic processes such as eluviation and illuviation. We found no evidence of 
Table 5

\begin{tabular}{|c|c|c|c|c|c|c|c|c|c|c|c|c|}
\hline Locality & Epoch & $\begin{array}{l}\text { Latitude } \\
\text { (degrees N) }\end{array}$ & $\begin{array}{l}\text { Longitude } \\
\text { (degrees W) }\end{array}$ & Geomorphology & $\begin{array}{l}\text { Depth interval } \\
(\mathrm{m})\end{array}$ & $\begin{array}{l}\text { Dating } \\
\text { method }\end{array}$ & $\begin{array}{l}\text { Minimum age } \\
\text { (cal yr BP) }\end{array}$ & $\begin{array}{l}\text { Maximum age } \\
\text { (cal yr BP) }\end{array}$ & $\begin{array}{l}\text { Accumulation } \\
(\mathrm{m} / \mathrm{yr})\end{array}$ & $\begin{array}{l}\text { Bulk density } \\
\left(\mathrm{g} / \mathrm{cm}^{3}\right)\end{array}$ & $\begin{array}{l}\text { MAR } \\
\left(\mathrm{g} / \mathrm{m}^{2} / \mathrm{yr}\right)\end{array}$ & Reference \\
\hline Near Sagwon & $\begin{array}{l}\text { Holocene } \\
\text { (late) }\end{array}$ & 69.35 & 148.75 & Poorly drained loess & $0.48-0.60$ & ${ }^{14} \mathrm{C}$ & 0 & 5820 & 0.000002061 & 1.45 & 3 & $\begin{array}{l}\text { Everett and Brown } \\
\text { (1982) }\end{array}$ \\
\hline Near Sagwon & $\begin{array}{l}\text { Holocene } \\
\text { (early) }\end{array}$ & 69.35 & 148.75 & Poorly drained loess & $0.73-0.80$ & ${ }^{14} \mathrm{C}$ & 5820 & 9204 & 0.000020685 & 1.45 & 30 & $\begin{array}{l}\text { Everett and Brown } \\
\text { (1982) }\end{array}$ \\
\hline $\begin{array}{l}\text { Brooks Range, } \\
\text { Slope } \mathrm{Mt}\end{array}$ & Holocene & 68.71 & 148.99 & Upland loess on till & $0.0-0.25$ & ${ }^{14} \mathrm{C}$ & 0 & 12634 & 0.000019787 & 1.45 & 29 & Dixon (1975) \\
\hline $\begin{array}{l}\text { Koyukuk, S. } \\
\text { Brooks Range }\end{array}$ & Pleistocene & 67.05 & 151.11 & Loess on outwash & $2.0-4.5$ & ${ }^{14} \mathrm{C}$ & 15819 & 18464 & 0.000945179 & 1.45 & 137 & Hamilton (1982) \\
\hline Epiguruk & Pleistocene & 67.08 & 158.17 & Upland loess on till & $0-10$ & ${ }^{14} \mathrm{C}$ & 9846 & 38580 & 0.00034802 & 1.45 & 505 & $\begin{array}{l}\text { Hamilton and } \\
\text { Ashley (1993) }\end{array}$ \\
\hline $\begin{array}{l}\text { Egg Lake, } \\
\text { Seward Penin. }\end{array}$ & Pleistocene & 66.55 & 164.44 & Poorly drained loess & $0.3-1.0$ & ${ }^{14} \mathrm{C}$ & 21382 & 22901 & 0.00046082 & 1.45 & 668 & $\begin{array}{l}\text { Höfle and Ping } \\
\text { (1996) } \\
\text { Höfle et al. (2000) }\end{array}$ \\
\hline $\begin{array}{l}\text { Chatanika } \\
\text { River }\end{array}$ & Holocene & 65.09 & 147.73 & Valley loess & $0-1.2$ & ${ }^{14} \mathrm{C}$ & 0 & 9529 & 0.000125931 & 1.45 & 183 & Péwé (1975b) \\
\hline $\begin{array}{l}\text { Chatanika } \\
\text { River }\end{array}$ & Pleistocene & 65.09 & 147.73 & Valley loess & $1.2-5.9$ & ${ }^{14} \mathrm{C}$ & 9529 & 17664 & 0.00057775 & 1.45 & 838 & Péwé (1975b) \\
\hline $\begin{array}{l}\text { Fairbanks, } \\
\text { Goldstream }\end{array}$ & Holocene & 64.94 & 147.65 & Valley loess & $0-2.36$ & ${ }^{14} \mathrm{C}$ & 0 & 8110 & 0.000290998 & 1.45 & 422 & Bégét (1990) \\
\hline Fairbanks, Fox & Holocene & 64.94 & 147.65 & Valley loess & $0-3.7$ & ${ }^{14} \mathrm{C}$ & 0 & 9488 & 0.000389966 & 1.45 & 565 & $\begin{array}{l}\text { Hamilton et al. } \\
\text { (1988) }\end{array}$ \\
\hline Fairbanks, Fox & Pleistocene & 64.94 & 147.65 & Valley loess & $3.7-10.4$ & ${ }^{14} \mathrm{C}$ & 9488 & 33960 & 0.000273782 & 1.45 & 397 & $\begin{array}{l}\text { Hamilton et al. } \\
\text { (1988) }\end{array}$ \\
\hline $\begin{array}{l}\text { Fairbanks, } \\
\text { Chena }\end{array}$ & Holocene & 64.91 & 147.45 & Upland loess & $0-1.3$ & ${ }^{14} \mathrm{C}$ & 0 & 11814 & 0.000110038 & 1.45 & 160 & This study \\
\hline $\begin{array}{l}\text { Fairbanks, } \\
\text { Chena }\end{array}$ & Pleistocene & 64.91 & 147.45 & Upland loess & $1.3-1.7$ & ${ }^{14} \mathrm{C}$ & 11814 & 36220 & 0.000016389 & 1.45 & 24 & This study \\
\hline Halfway House & Holocene & 64.72 & 147.5 & Upland loess & $0.53-1.88$ & ${ }^{10} \mathrm{Be}$ & 0 & 9680 & 0.000187241 & 1.45 & 187 & This study \\
\hline Halfway House & Pleistocene & 64.72 & 147.5 & Upland loess & $1.88-3.69$ & ${ }^{10} \mathrm{Be},{ }^{14} \mathrm{C}$ & 10495 & 16082 & 0.000323966 & 1.45 & 470 & This study \\
\hline $\begin{array}{l}\text { Nome, Seward } \\
\text { Peninsula }\end{array}$ & Holocene & 64.52 & 165.49 & Valley loess & $0.61-1.07$ & ${ }^{14} \mathrm{C}$ & 2853 & 11162 & 0.000055361 & 1.45 & 80 & $\begin{array}{l}\text { Hopkins et al. } \\
(1960)\end{array}$ \\
\hline $\begin{array}{l}\text { Nome, Seward } \\
\text { Peninsula }\end{array}$ & Pleistocene & 64.52 & 165.49 & Valley loess & $1.07-1.37$ & ${ }^{14} \mathrm{C}$ & 11162 & 15678 & 0.00006643 & 1.45 & 96 & $\begin{array}{l}\text { Hopkins et al. } \\
(1960)\end{array}$ \\
\hline $\begin{array}{l}\text { Shaw Creek } \\
\text { Flats }\end{array}$ & Holocene & 64.27 & 146.1 & $\begin{array}{l}\text { Upland loess, } \\
\text { colluvium }\end{array}$ & $0.40-0.93$ & ${ }^{14} \mathrm{C}$ & 0 & 10715 & 0.000049463 & 1.45 & 72 & This study \\
\hline Delta Junction & Holocene & 64.09 & 145.76 & Loess on outwash & $2.75-4.5$ & ${ }^{14} \mathrm{C}$ & 0 & 2728 & 0.001063049 & 1.45 & 1541 & This study \\
\hline $\begin{array}{l}\text { Dawson, } \\
\text { Yukon Terr. }\end{array}$ & Pleist./Holo. & 63.75 & 139 & Valley loess & $2.0-20.0$ & ${ }^{14} \mathrm{C}$ & 7269 & 27000 & 0.00091227 & 1.45 & 1323 & $\begin{array}{l}\text { Fraser and Burn } \\
\text { (1997) }\end{array}$ \\
\hline $\begin{array}{l}\text { St. Michael } \\
\text { Island }\end{array}$ & Holocene & 63.5 & 162.17 & Lacustrine sediments & $0-1.35$ & ${ }^{14} \mathrm{C}$ & 0 & 8407 & 0.00016058 & 0.63 & 101 & Ager (1982) \\
\hline $\begin{array}{l}\text { St. Michael } \\
\text { Island }\end{array}$ & Pleist./Holo. & 63.5 & 162.17 & Lacustrine sediments & $1.35-3.30$ & ${ }^{14} \mathrm{C}$ & 8407 & 18642 & 0.000190522 & 0.63 & 120 & Ager (1982) \\
\hline $\begin{array}{l}\text { Matanuska } \\
\text { Valley }\end{array}$ & Holocene & 61.57 & 149.18 & Upland loess & $0-1.50$ & ${ }^{14} \mathrm{C}$ & 0 & 6429 & 0.000233317 & 1.45 & 338 & Fontana (1988) \\
\hline Kenai area & Holocene & 60.52 & 150.8 & Upland loess & $0.0-0.41$ & ${ }^{14} \mathrm{C}$, tephras & 0 & 1600 & 0.00025625 & 1.45 & 372 & Reger et al. (1996) \\
\hline Kenai area & Holocene & 60.47 & 151.12 & Upland loess & $0.10-0.70$ & ${ }^{14} \mathrm{C}$, tephras & 0 & 8375 & 0.000071641 & 1.45 & 104 & Reger et al. (1996) \\
\hline $\begin{array}{l}\text { Ahklun } \\
\text { Mountains }\end{array}$ & Holocene & 59.92 & 160.3 & Loess on diamicton & $0.0-0.32$ & ${ }^{14} \mathrm{C}$ & 0 & 5844 & 0.000054757 & 1.45 & 79 & Manley et al. (2001) \\
\hline $\begin{array}{l}\text { Kvichak } \\
\text { Peninsula }\end{array}$ & Pleist./Holo. & 58.62 & 158.23 & $\begin{array}{l}\text { Upland loess on older } \\
\text { till }\end{array}$ & $1.0-2.0$ & ${ }^{14} \mathrm{C}$ & 8390 & 15401 & 0.000142633 & 1.45 & 207 & Ager (1982) \\
\hline
\end{tabular}


argillic B horizons in the field or significant changes in soil texture that would suggest a buildup of illuvial clay. An examination of the abundance of fine $(2-20 \mu \mathrm{m})$ silt shows that this particle size fraction is correlated positively with clay content (Figs. 8, 10, 16). Fine silt and clay contents track each other in close phasing through the loess sections at Halfway House, Gold Hill and Birch Hill and suggest the mechanism of fine (claysized) particle enrichment. Fine silt particles are not known to be produced in large quantities by any pedogenic mechanism. Thus, the greater abundance of these particles in palaeosols suggests that fine-silt enrichment has a sedimentological origin. Because clay content is positively correlated with fine silt content, we also consider that relatively high clay contents in palaeosols result from fine particle sedimentation. If this interpretation is correct, two possible scenarios of fine particle additions are inferred. One possibility is that the high fine silt and clay contents represent the waning stages of loess accretion, when wind strengths have diminished and loess sedimentation has nearly terminated. Soils then developed in the uppermost, finegrained part of the loess. One problem with this explanation is that immediately under each palaeosol, the lowest concentrations of fine silt and clay are found; in other words, the loess packages are coarsening upwards, not fining upwards. Alternatively, although the very presence of buried soils indicates a reduction in the rate of sedimentation, it is also possible that fine loess accretion may go on at a low rate, with only very fine particles, during pedogenesis. Begét (1996) pointed out that dust storms occur at the present time in the Fairbanks area and there is a low but measurable flux of dust in the lower troposphere of the region. These observations suggest that, during periods dominated by loess sedimentation, winds may be so strong that only coarse particles (coarse silts and some fine silts) settle out. In contrast, during periods of soil formation, loess deposition may occur at a low rate and under generally weaker winds, such that only fine particle (fine silts and clays) accretion takes place. This model is similar to what Begét et al. (1990) proposed for Alaskan loess, using magnetic susceptibility as a proxy for heavy mineral content and wind competence. With this kind of depositional regime, Alaskan loess-palaeosol sequences are analogous to those in China where, as described by Verosub et al. (1993), loess deposition and pedogenesis are essentially competing processes that continue during both glacials and interglacials. In contrast, changes in loess particle size in midcontinental North America appear to be largely a function of distance from a source, changes in source over time, or pedogenesis (Ruhe, 1983; Muhs and Bettis, 2000).

Loess particle size is not uniform within each depositional package. At Halfway House, Birch Hill and Gold Hill, fine silt, clay and $\mathrm{Al}_{2} \mathrm{O}_{3}$ contents in unaltered loess are highest immediately above each palaeosol and decrease steadily to minimum values immediately below the next-youngest palaeosol. This observation indicates that once rapid loess sedimentation begins after a period of pedogenesis, initial particles are relatively fine-grained and become coarser grained as the loess sedimentation phase of the cycle progresses. The coarsest particles are found in the youngest part of each loess package, suggesting that wind competence was greatest near the end of each depositional cycle.

\subsection{Chronology of loess deposition}

The stratigraphic and geochronologic data presented here indicate that the Fairbanks area contains a detailed record of loess deposition and soil development over much of the late Quaternary. Climate changes of the last interglacial-glacial cycle are represented as alternating periods of loess fall and pedogenesis, but a correlation with global records is not simple (Fig. 17). The oxygen isotope record in deep-sea cores (Martinson et al., 1987) and the emergent marine record (e.g., Muhs et al., 2002) indicate that the last interglacial period, sensu lato (represented by all of deep-sea stage 5), may have been a long, complex interval, of the order of 50,000-60,000 yr, with at least three relatively warm peaks. These warm periods correspond to oxygen isotope substages $5 \mathrm{e}$ $(\sim 125,000 \mathrm{yr} \quad \mathrm{BP}), \quad 5 \mathrm{c} \quad(\sim 100,000 \mathrm{yr} \quad \mathrm{BP})$ and $5 \mathrm{a}$ ( $\sim 80,000 \mathrm{yr} \mathrm{BP})$. In central Alaska, no single section appears to have a complete record of all three of these warm periods. At Eva Creek, pedogenesis during the peak of the last interglacial period (substage 5e), or at least part of it, may be represented by the palaeosol associated with the Eva Forest Bed (Muhs et al., 2001a). The Eva Forest Bed contains the Old Crow tephra in its upper part and is overlain by unaltered loess that contains the Dome tephra. At Birch Creek, north of Fairbanks, McDowell and Edwards (2001) also reported that a palaeosol developed in loess contains the Old Crow tephra. At Halfway House, the Old Crow tephra is present, but we found no evidence of a paleosol resembling that of the Eva Forest Bed associated with it, and there is no evidence for the Dome tephra. At Gold Hill, although we did not find the Old Crow tephra, the paleosol at $\sim 660-770 \mathrm{~cm}$ depth contains the Dome tephra in its upper part. At Chena Hot Springs Road, the Old Crow tephra is also missing, but the Dome tephra occurs beneath a palaeosol, not in its upper part.

Our interpretation of these highly variable stratigraphic records is that numerous unconformities must exist within Fairbanks-area loess sections and any correlation with a global record of glacial-interglacial cycles is likely to be very tentative. A common practice among workers studying the Alaskan Quaternary record has been to use the rough average ( $\sim 140,000$ cal yr BP) of Westgate's $(1988,1989)$ isothermal plateau fission 


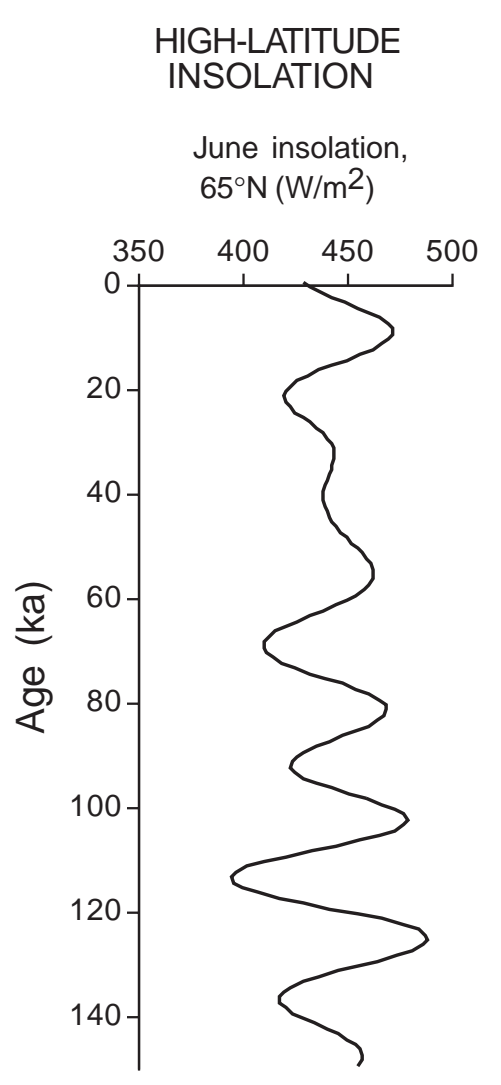

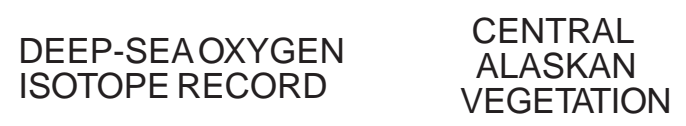

COMPOSITE

ALASKAN LOESS

RECORD

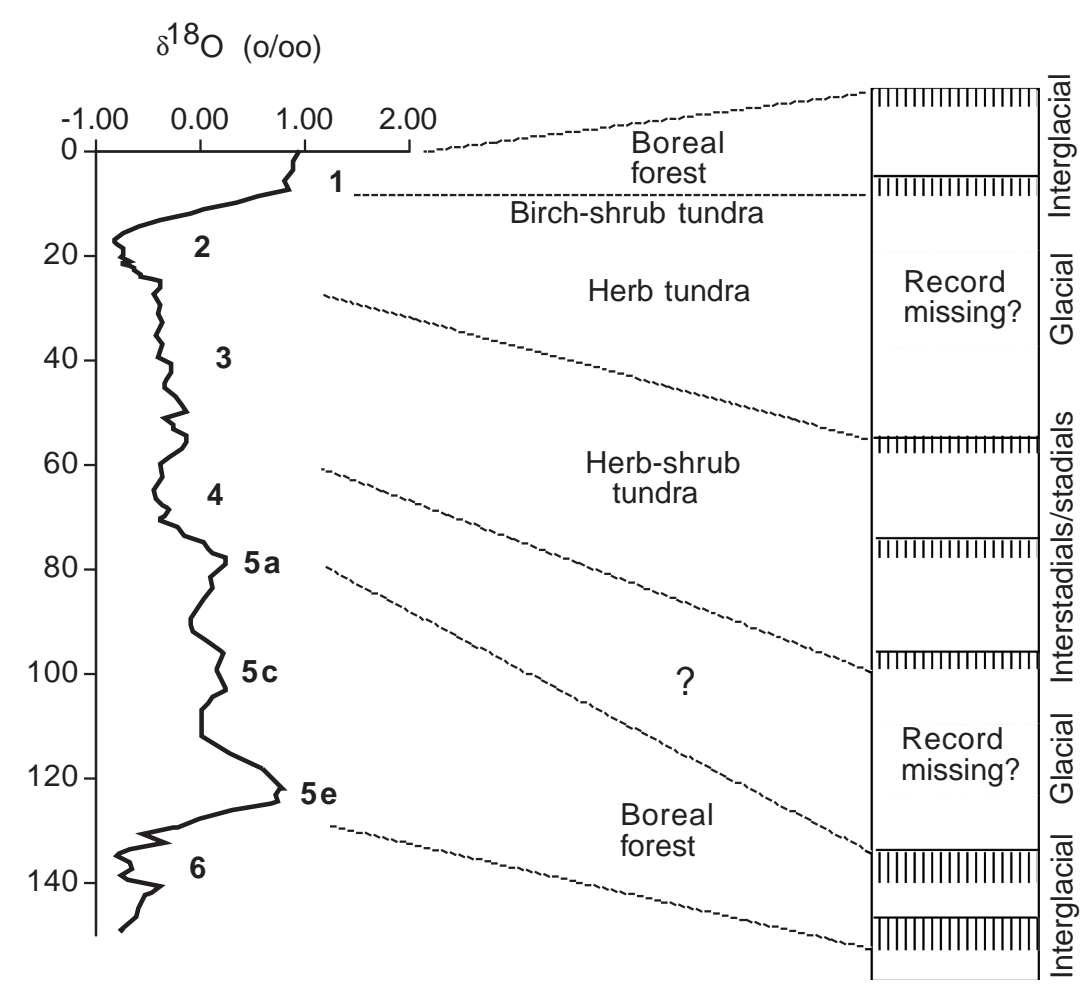

Fig. 17. Composite loess stratigraphy in central Alaska compared with estimated vegetation types in the region over the last interglacial-glacial cycle (from Ager and Brubaker, 1985, Edwards et al., 2001; Muhs et al., 2001a), the deep-sea oxygen isotope record (Martinson et al., 1987), and summer insolation at the top of the atmosphere in the latitude of Fairbanks (Berger and Loutre, 1991).

track ages of the Old Crow tephra to assume a pre-lastinterglacial age for this unit (e.g., Hamilton, 2001; Lagroix and Banerjee, 2002). While this assumption is permissible, it is not required; the individual fission track ages and their analytical uncertainties also permit a last-interglacial age or even a post-last-interglacial age for the Old Crow tephra. This point is important because it means that, in those loess sections where the Old Crow tephra is absent, there is no implication that a palaeosol dating from the last interglacial period is absent. Based on current information, the well-developed palaeosols that occur at intermediate depths in the loess sections we have studied could date from any of the substages of oxygen isotope stage 5 or some combination of them. In addition, the Dome tephra occurs below a palaeosol at one locality (Chena Hot Springs Road), in the upper part of a palaeosol at another (Gold Hill), and in unaltered loess at yet another (Eva Creek; see Muhs et al., 2001a). These observations suggest that different parts of the Fairbanks area could have experienced landscape stability (Gold Hill) or loess accretion (Chena Hot Springs Road and Eva Creek) at the same time.
Much of the mid-Wisconsin period may be represented by alternating thin loess and minimally developed palaeosols in the Fairbanks area. At least two palaeosols that could date to $\sim 29,000-30,000{ }^{14} \mathrm{C}$ yr BP are found at Halfway House, Gold Hill and Chena Hot Springs Road. A palaeosol with a charcoal radiocarbon age dating to $\sim 42,000{ }^{14} \mathrm{C}$ yr BP is found at Birch Hill; lessreliable humic acid ages in this range are also found at Halfway House, Gold Hill and Chena Hot Springs Road, stratigraphically below the $\sim 30,000 \mathrm{yr}$ BP palaeosols. The stratigraphic and radiocarbon data suggest that in the period since the last interglacial period and before the last glacial period, environmental conditions alternated several times between those favouring loess accumulation and those favouring soil formation, consistent with a recent review of pollen data for Beringia in this time period (equivalent to oxygen isotope stage 3) by Anderson and Lozhkin (2001). Summer insolation in the latitude of Fairbanks was variable during this period (Berger and Loutre, 1991) and the deep-sea oxygen isotope record indicates that conditions were neither of full-interglacial nor fullglacial character (Martinson et al., 1987). Studies 
elsewhere at high latitudes in the Northern Hemisphere support the idea of many rapid and dramatic climate shifts in this time period that are not easily explained by high-latitude insolation variations. Detailed, high-resolution oxygen isotope studies of cores taken in the Greenland ice sheet show that between the peak of the last interglacial period and the last glacial maximum, there may have been as many as 23 warm interstadial periods (Grootes et al., 1993). Grootes et al. (1993) estimate that although the last glacial period may have been $10-13^{\circ} \mathrm{C}$ cooler than the Holocene, many of the interstadials were only $\sim 3^{\circ} \mathrm{C}$ cooler than the Holocene. If similar climate shifts occurred in Alaska, much of which is in the same latitudinal zone as Greenland, then it would not be surprising to find a herb-shrub tundra during the warmer interstadials, but increased loess production during the intervening cool (herb tundra?) periods. Although Alaskan loess obviously does not have the dating resolution of Greenland ice cores, several periods of palaeosol formation between $\sim 50,000$ and $\sim 30,000 \mathrm{yr}$ BP could correspond to dated midWisconsin interstadials in the Greenland oxygen isotope record.

An unexpected result of our studies is the minimal evidence for major loess deposition during the last glacial period. In midcontinental North America, Peoria (last glacial) loess is by far the thickest deposit encountered at virtually every locality (see Bettis et al., 2003). In central Alaska, most localities show only modest amounts of loess deposited during the last glacial period and some localities show little or no deposition. The potentially greatest amount of last glacial loess deposited is found at Halfway House, where as much as $3-4 \mathrm{~m}$ of loess may have been deposited during the last glacial period if we accept the ${ }^{10} \mathrm{Be}$ age estimates reported in the present study. Nevertheless, the ${ }^{10} \mathrm{Be}$ ages do not preclude the possibility that much of the loess in the upper $4 \mathrm{~m}$ of the section was deposited during the early Holocene. A maximum of about $3 \mathrm{~m}$ of loess deposited during the last glacial period may exist at Birch Hill but, because we have only a maximum-limiting age of $\sim 27,000{ }^{14} \mathrm{C}$ yr $\mathrm{BP}$, all of the loess in the upper part of that section could be Holocene. At Chena Hot Springs Road, a maximum of $\sim 1.0 \mathrm{~m}$ of loess may have been deposited between $\sim 32,210$ and $\sim 9750{ }^{14} \mathrm{C}$ yr BP (Fig. 18). The ${ }^{10} \mathrm{Be}$ age estimates for Gold Hill suggest that around $2 \mathrm{~m}$ of loess may have been deposited between $\sim 13,000$ and $\sim 8000$ cal yr BP. However, as with Birch Hill and Halfway House, these age estimates do not preclude most loess deposition having taken place during the early Holocene.

Radiocarbon ages of $\sim 9000-8000{ }^{14} \mathrm{C}$ yr BP from charcoal at Chena Hot Springs Road and less than
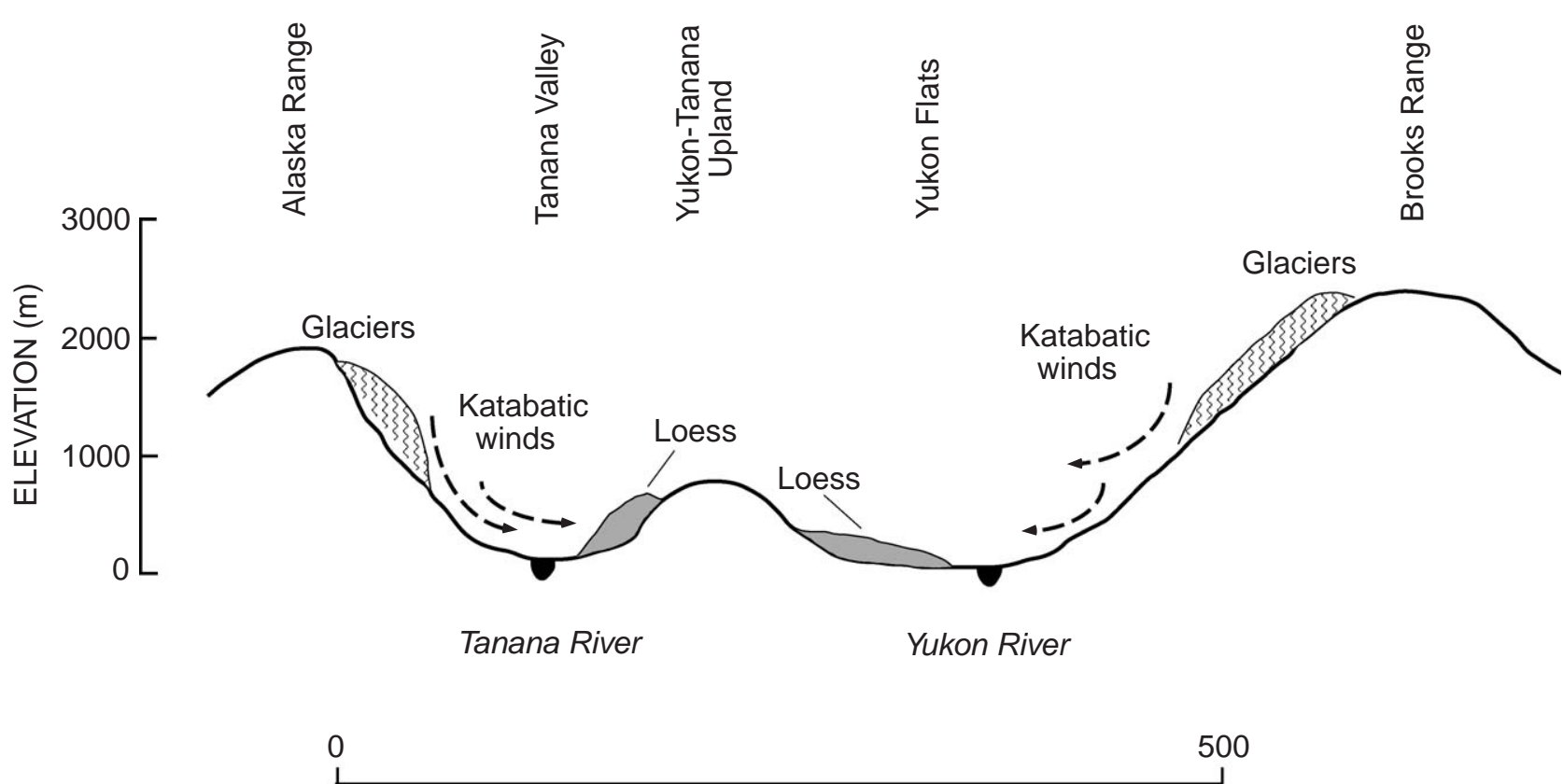

KILOMETRES

Fig. 18. Schematic north-south topographic profile of central Alaska showing location of loess deposits (thicknesses exaggerated) relative to source rivers and flow of katabatic winds during the last glacial period. 
$\sim 3000{ }^{14} \mathrm{C}$ yr BP from wood at Delta Junction indicate that Holocene loess deposition took place in central Alaska. These results confirm earlier reports of Holocene loess sedimentation in these areas by Péwé (1975a, b), Hamilton et al. (1983) and Begét (1990). In addition, although it has been known for some time that late Holocene loess deposition has taken place near Delta Junction (see Péwé, 1975b), the new stratigraphic data presented here show that this sedimentation was episodic. The presence of at least two palaeosols in a loess section that dates to the past $\sim 3000{ }^{14} \mathrm{C}$ yr BP indicates that three periods of loess deposition occurred, separated by periods of pedogenesis.

\subsection{Loess and palaeowinds}

Loess is often an unusually valuable proxy of past atmospheric circulation because it is directly deposited by the wind. In the North American midcontinent, many properties, such as loess thickness, particle size and geochemistry have systematic changes in a downwind direction from a source (Ruhe, 1983; Muhs and Bettis, 2000; Bettis et al., 2003). Unfortunately, in the Fairbanks area, the geographic extent of loess away from potential source sediments is too limited for meaningful application of these methods. Instead, we consider likely sources based on geochemical data presented earlier and discuss these possibilities in the light of palaeowinds from the aeolian sand record.

There are now enough dated, last glacial aeolian sand bodies, either sand sheets or dunes, to provide an overall picture of last-glacial palaeowinds in Alaska. Aeolian sand dating to the last glacial period can give palaeowind directions based on geomorphology (dune morphological trends), azimuths of steep foreset beds, geographic position of aeolian sand bodies relative to probable sources, and thickness trends away from probable sources. Using these criteria, Hopkins (1982), and Lea and Waythomas (1990) show that during the last glacial period and particularly in the late glacial period, winds were mostly from the northeast in Alaska. We assume that during the last glacial period, most aeolian sand movement took place during summer months, when sediment was unfrozen, snow cover was absent and outwash sediment derived from summer ablation was abundant. Interestingly, the reconstructed palaeowinds from the aeolian sand record do not agree with AGCM simulations. AGCM simulations of last glacial palaeowinds in Alaska (both the NCAR CCM0 and CCM1 models) suggest that full glacial palaeowinds in this region came from the south in winter or southwest in summer (Bartlein, 1997; Bartlein et al., 1998). Both simulations suggest that full glacial summer and winter winds were stronger than at present, which would have favoured greater aeolian sand movement. However, it is not clear why there is such a discrepancy between the palaeowinds from the aeolian sand record and the AGCM results.

If we assume that palaeowinds, as derived from the aeolian sand record, approximate the circulation regime of the last glacial period, complications arise concerning the distribution of loess bodies relative to probable sources. In the Yukon Flats region, we believe that the relatively carbonate-rich loess was derived from the Brooks Range, as discussed earlier. Because this loess is found largely to the south of the Yukon River, deposition during full glacial time is explained by northeasterly winds. Such an explanation requires that most loess in the Yukon Flats area is of full-glacial age, a hypothesis that is, at this point, untested. However, in the Fairbanks area, loess is most likely derived primarily from the Tanana River and its tributaries. This inference is based on Péwé's (1955) data, which show that the mineralogy and geochemistry of the local bedrock of the Yukon-Tanana Upland does not match the loess. If this is the case, then southerly winds would be required for loess deposition from this source, at least during full glacial time. Reconciliation of these contradictory observations is possible if we consider local wind effects on loess distribution. Both Thorson and Bender (1985) and Guthrie (1990, p. 54) have suggested that katabatic winds, derived from expanded glaciers in the Alaska Range, would have produced strong, southerly winds, at least locally, to the north of the mountain front. If this is the case for the Brooks Range as well, then strong local winds from the north would be superimposed on regional northerly winds and would easily explain the distribution of loess mainly to the south of the Yukon River (Fig. 18). Theoretical considerations as well as field data presented by Thorson and Bender (1985) show that katabatic winds were probably very localized; thus, derivation of loess from southerly winds in the Fairbanks area does not necessarily contradict formation of the nearby Kantishna Sand Sea (see Lea, 1996) from northerly winds. If this scenario is correct, then loess transport in Alaska during full glacial time was a function not only of synoptic-scale wind regimes, but also of local winds derived from expanded glaciers.

\subsection{Controls on loess production and accumulation}

There is little question that during the last glacial period in Alaska, climatic conditions were colder (at least in summer) and drier than at present, based on both empirical studies and modeling efforts. The result of this is that glaciers in all mountain ranges expanded (Hamilton, 1994), continental shelf areas were exposed, vegetation was dominated by herb tundra (Ager and Brubaker, 1985; Anderson and Brubaker, 1994) and vegetation cover itself was probably sparser than it is now (Fig. 19). Because of exposure of the nowsubmerged shelf, interior Alaska would have been even 


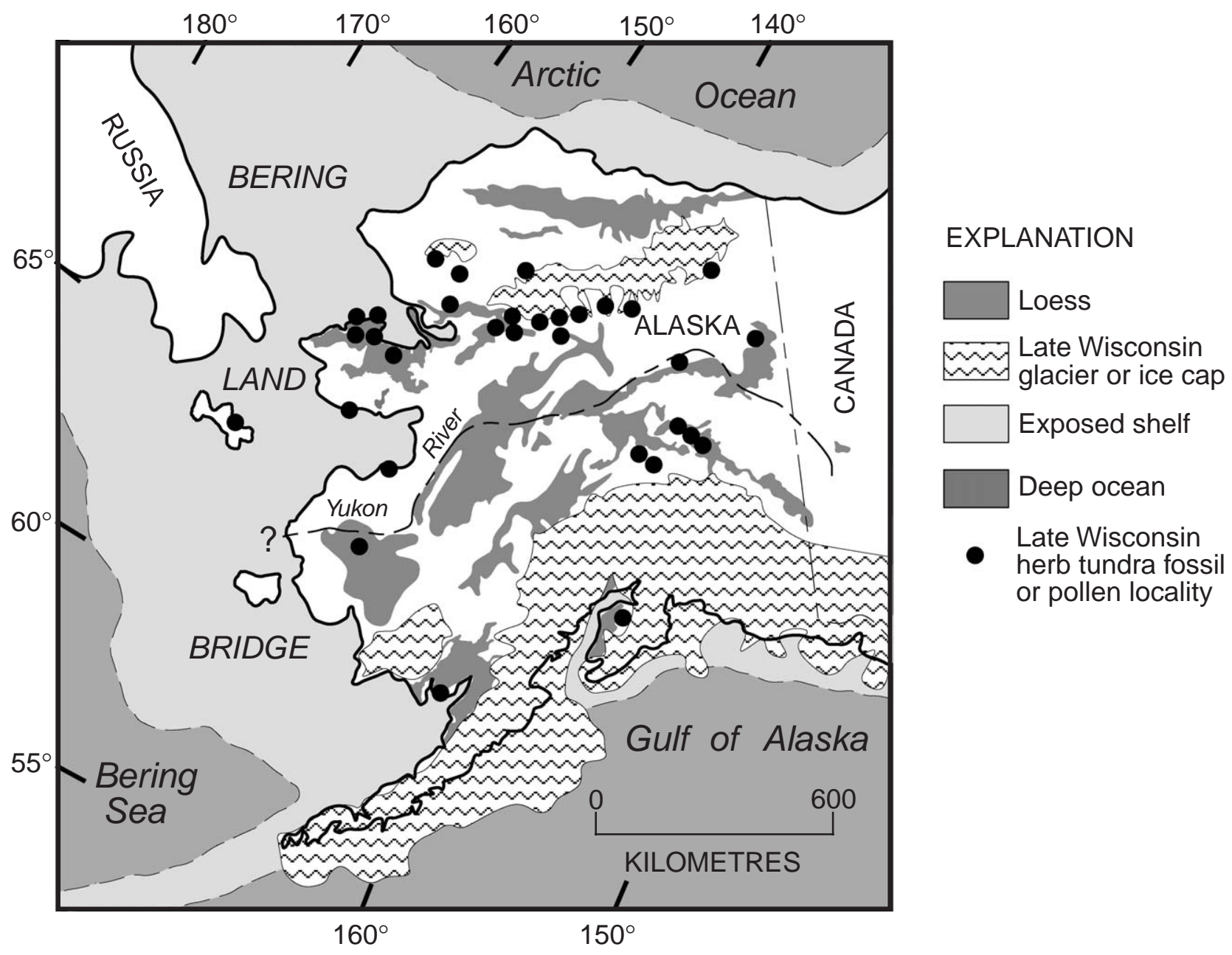

Fig. 19. Palaeogeography of Alaska during the last glacial period. Loess is modified from Péwé (1975a, b); extent of glaciers is from Hamilton (1994); last glacial herb tundra pollen or macrofossil localities compiled from Ager (1975, 1982, 1983, 1989), Ager and Brubaker (1985), Anderson and Brubaker (1994) and Goetcheus and Birks (2001).

more continental than it is at present. It is also likely that winds were stronger because of an increased equator-to-pole thermal gradient. Based on these climatic conditions, it is possible to construct a process-response geomorphic model for enhanced last glacial loess production in Alaska (Fig. 20). This model is fashioned after that presented by Muhs and Holliday (1995) for enhanced Holocene aeolian sand deposition in the North American Great Plains. In constructing a model for enhanced glacial loess production in Alaska, we also incorporate the concepts of sediment supply, availability, and transport limitations on aeolian particle movement (Kocurek and Lancaster, 1999). Thus, the full glacial climate in Alaska would have produced: (1) larger glaciers with more production of silt-sized particles by glacial grinding as well as by increased frost weathering (greater sediment supply); (2) formation of wide, braided river channels, an exposed continental shelf, and decreased vegetation cover (greater sediment availability); and (3) strong winds over a sparsely distributed herb-tundra vegetation with a low roughness height (fewer transport limitations). Recent linked AGCM-biome-biogeochemistry models have suggested that, under full-glacial conditions, Alaska should have been an important dust source, even without consideration of the enhanced silt production from the growth of glaciers (Mahowald et al., 1999; Kohfeld and Harrison, 2000).

Recent laboratory simulations and theoretical models have challenged the concept that glaciers are the main source of silt for loess. These studies have emphasized the roles played by in situ weathering, fluvial comminution, and aeolian abrasion for silt formation (Wright, 2001a, b). Based on our own work in the Great Plains of North America, we agree that not all loess is derived from glaciogenic sources (Aleinikoff et al., 1998, 1999; Muhs et al., 1999a). Nevertheless, there is little question that abundant silt is produced by glacial processes in 


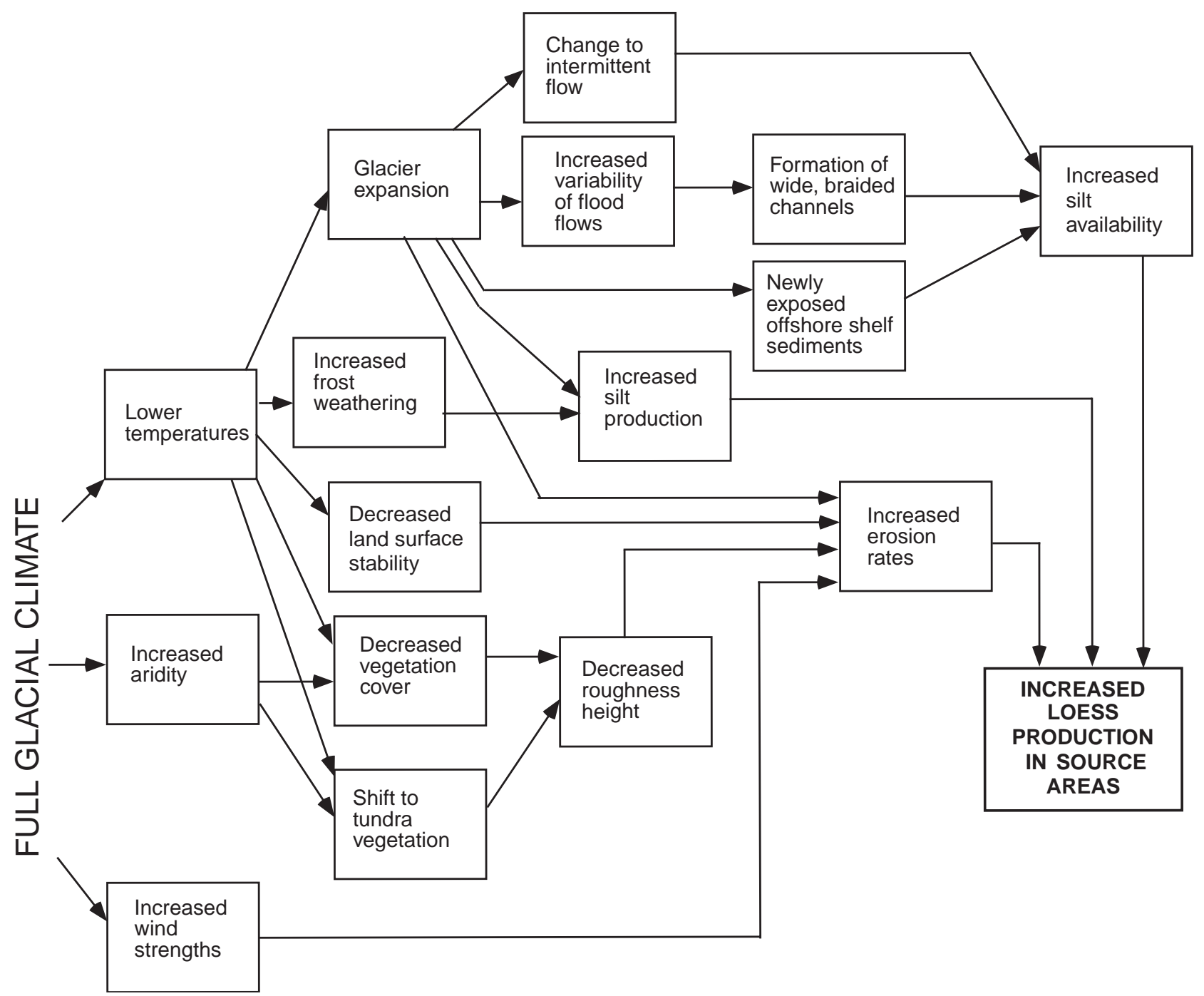

Fig. 20. Process-response model of enhanced loess production during the last glacial period in Alaska.

Alaska. In all areas we have observed that, immediately downstream from active glaciers in the Alaska Range, outwash valleys are extremely silt-rich, despite the fact that bedrock in the source areas is not siltstonedominated (as it is in parts of the Great Plains). Furthermore, analysis of suspended sediment data from streams in Alaska has shown that sediment yields are positively correlated with the amount of glacial cover in a drainage system (Hallet et al., 1996). In fact, these studies have shown that basins with $\geqslant 30 \%$ glacier cover have sediment yields about an order of magnitude higher than the amount of sediment in basins without glaciers. We conclude from these considerations that most silt in Alaskan loess is glaciogenic and that, during the last glacial period, silt production by glaciers was greater than at present.

If conditions were conducive to greater silt production, greater silt availability and increased wind strength, it is surprising to find such a minimal record of last glacial loess deposition in central Alaska. Part of the explanation for this unexpected result may be related to the conditions favouring loess production versus conditions favouring loess accumulation. Some of the same conditions that would bring about greater sediment availability in loess source regions would also bring about a decreased likelihood of loess accumulation downwind. Hence, we have constructed another model (Fig. 21) that shows the effect of full glacial climates on the loess accumulation capability in areas receiving dust. The greater continentality, decreased moisture sources, lower temperatures, and increased aridity of central Alaska would have resulted in an herb tundra vegetation and it is possible that vegetation cover was not continuous over many parts of the landscape (Ager and Brubaker, 1985; Anderson and Brubaker, 1994). Herb tundra vegetation has a very low roughness 


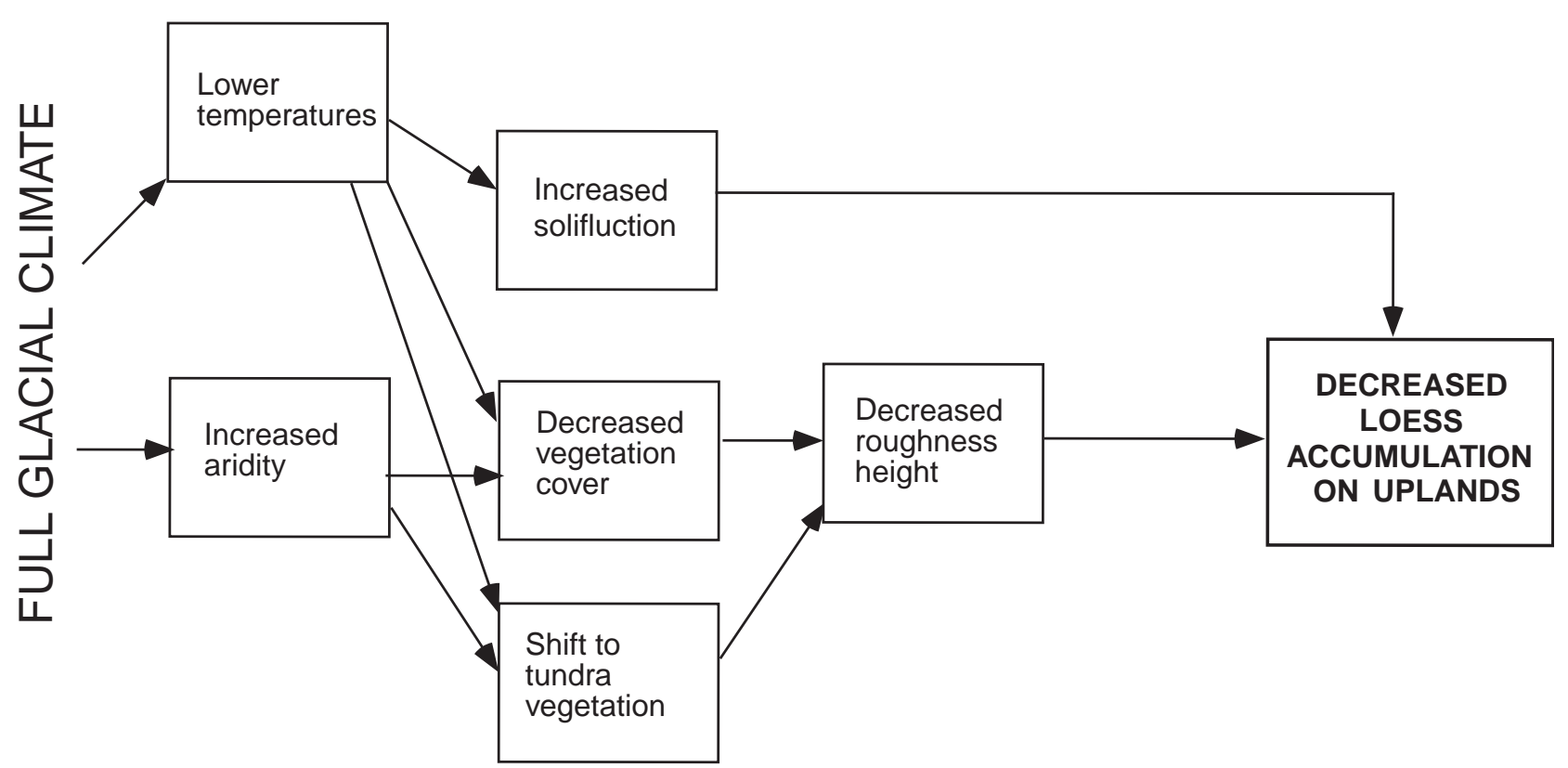

Fig. 21. Process-response model of decreased loess accumulation during the last glacial period in Alaska.

height, even lower than grass and more than an order of magnitude lower than forest (see Tsoar and Pye, 1987). As a result, many upland regions, including those in interior Alaska, would have had little dust-trapping capability compared to their present potential under a cover of boreal forest vegetation. This model was proposed by Begét (1988) even before much was known about the stratigraphy and geochronology of central Alaskan loess.

The effectiveness of boreal forest compared to tundra as a loess trap can be illustrated by examining the distribution and thickness of loess in the area around Delta Junction, where loess is being actively deflated from silt-covered portions of the modern floodplain of the Delta River. Detailed mapping of loess distribution and thickness in this area by Lindholm et al. (1959) and Péwé and Holmes (1964), and the position of forest versus tundra (mapped by the present investigators), shows that most loess is found only in the boreal forest. Indeed, the efficiency of boreal forest as a dust trap is confirmed by our observations that the bases of tree trunks near Delta Junction are blanketed with modern loess. In contrast, we have observed that most upland surfaces above treeline in the region have either thin loess or no loess at all. The stratigraphic record for the Fairbanks area supports the concept of the importance of boreal forest for trapping loess. At Chena Hot Springs Road, the Fox permafrost tunnel near Fairbanks (Hamilton et al., 1988), and Chatanika River and Ready Bullion Creek west of Fairbanks (Péwé, 1975b, pp. 17, 21), there are $1-4 \mathrm{~m}$-thick accumulations of Holocene loess that have basal radiocarbon ages of
$8000-10,000{ }^{14} \mathrm{C}$ yr BP. Ager and Brubaker (1985), in a compilation of pollen data from numerous lakes, show that spruce arrived in central Alaska around 8000-9000 ${ }^{14} \mathrm{C}$ yr BP. We suggest that the accumulation of Holocene loess in central Alaska is to a great extent a function not of increased sediment supply but rather of increased sediment trapping ability by vegetation.

An important role for vegetation in loess accumulation may well explain why the loess stratigraphic records in midcontinental North America and Alaska are so different. Numerous pollen and macrofossil studies have shown that during full glacial time $\left(\sim 18,000-14,000{ }^{14} \mathrm{C}\right.$ yr BP), much of midcontinental North America was covered by spruce forest, similar to the modern boreal forest of Alaska and Canada (Baker et al., 1986; Wells and Stewart, 1987; Webb et al., 1993). Localities with either spruce macrofossils or pollen records dominated by spruce indicate that this full-glacial boreal forest had a geographic extent very similar to that of Peoria loess. Wright (1970, p. 166) may have been one of the earliest to speculate that this boreal forest served as an effective loess trap in midcontinental North America during the last glacial period. Our observations of loess distribution in the Delta Junction area and the loess stratigraphic record in the Fairbanks area support this hypothesis.

Another factor that may be partly responsible for the lack of a thick, last glacial loess record in interior Alaska is the lag of vegetation change behind summer warming. Post-glacial summer insolation at $\sim 65^{\circ} \mathrm{N}$ was above modern values by $\sim 17,000$ cal yr $\mathrm{BP}$ and reached its peak at $\sim 10,000$ cal yr BP (Berger and Loutre, 1991). However, as discussed above, Ager and Brubaker's 
(1985) compilation of pollen data show that shrub-birch tundra did not arrive in interior Alaska until $\sim 14,000$ cal yr BP, and spruce forest did not arrive until 900010,000 cal yr BP (Ager and Brubaker, 1985; Edwards et al., 2001). Thus, summer warming and associated melting of permafrost may have begun some time after 17,000 cal yr BP, but a stabilizing boreal forest vegetation (or even shrub-birch tundra) would not have arrived in central Alaska until thousands of years later. As a result, much loess that may have been deposited prior to $\sim 17,000$ cal yr BP, during the fullglacial period, may have been subjected to permafrost thaw, slumping, gullying and other processes that would have removed the record from upland settings before boreal forest or even shrub-birch tundra could have stabilized it.

\subsection{Loess stratigraphic model}

We have generated a loess stratigraphic model for North America that incorporates the concepts of loess production and loess accumulation potential (Fig. 22). The model suggests that three different stratigraphic records should be present in different parts of North America. In the Central Lowlands region of North America (where pre-settlement vegetation was dominantly deciduous forest), present loess accumulation potential is high, but production rates are low. Thus, no Holocene loess is seen in the stratigraphic record, although small increments of dust additions have been detected in modern soils (see Mason and Jacobs, 1998 and Muhs et al., 2001b). In contrast, during full-glacial time, loess production rates from the Laurentide ice sheet were high and the presence of boreal forest resulted in high accumulation rates. As a result, the last glacial loess of the Central Lowlands, east of the Mississippi and Missouri Rivers, has some of the thickest accumulations in the world (Pye and Johnson, 1988; Grimley et al., 1998; Markewich et al., 1998; Muhs and Bettis, 2000; Wang et al., 2000; Muhs et al., 2001b; Bettis et al., 2003). In the drier Great Plains portion of central North America, pre-settlement vegetation was grassland and some non-glacial sources of loess exist even today. Although accumulation potential (due to grassland vegetation) has been low in the Holocene, production rates have been moderate, and many localities in Nebraska, Kansas and Colorado have evidence of Holocene loess (see distribution in Muhs et al., 2001b). However, during the last glacial period, the Great Plains, like the Central Lowlands region, had both high rates of loess production and high accumulation potential. Both glacial and, more importantly, nonglacial sources of loess existed (Aleinikoff et al., 1998, 1999) and boreal forest (or, at least, parkland) existed at least as far west as northwestern Kansas (Wells and Stewart, 1987). Thus, thick loess accumulated in the Great Plains during the last glacial period as it did in the Central Lowland region. In Alaska, glaciers exist today and probably have existed throughout much of the Holocene. As a result, Holocene silt production is relatively high, at least in comparison to either the Central Lowlands or Great Plains regions of North America. In addition, the present boreal forest that covers much of interior Alaska provides a high

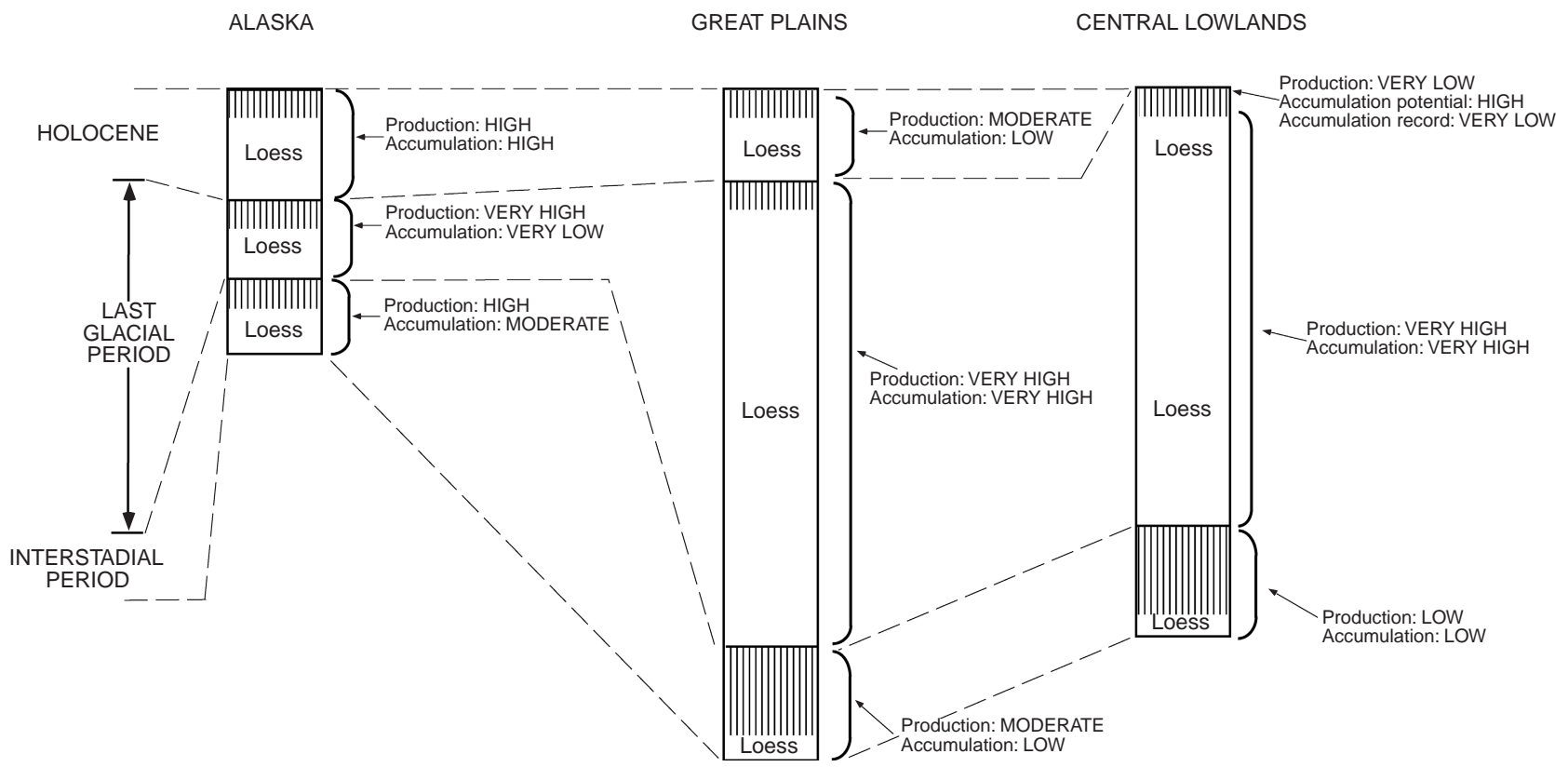

Fig. 22. Model of loess stratigraphic diversity in North America in the late Quaternary shown as a function of varying loess production and accumulation rates. 
accumulation potential. Therefore, Holocene loess is present over much of the region. During the last glacial period, silt production was probably even higher than it is today (Fig. 22), but accumulation potential was low due to the dominance of sparse, herb tundra vegetation.

Loess stratigraphic records from the Central Lowlands, the Great Plains and Alaska all show evidence of loess accumulation during stadial and/or interstadial periods that preceded the last glacial period. In both the Central Lowlands and Great Plains regions, although mid-Wisconsin localities are abundant, dating is not precise and only a general picture has emerged. Based on pollen evidence summarized by Baker and Waln (1985), the Central Lowlands region was probably forested during the mid-Wisconsin interstadial period around $34,000-28,000{ }^{14} \mathrm{C}$ yr BP. Farther west, on the Great Plains, conditions were drier, and based on both pollen and carbon isotope data, grassland may have been predominant in the interval from about 33,000 24,000 ${ }^{14} \mathrm{C}$ yr BP (Johnson, 1993; Fredlund, 1995). In Alaska, pollen and macrofossil data summarized by Anderson and Lozhkin (2001) suggest that a foresttundra may have existed in the Fairbanks area from about $35,000-30,000{ }^{14} \mathrm{C}$ yr BP. Given these probable vegetation types, we suggest that during the midWisconsin, loess accumulation potential was high in the Central Lowlands, low in the Great Plains, and moderate in Alaska. Unfortunately, we know little about probable silt production during this time interval in any of the three regions. It is likely that glacier ice was at least as extensive as it is today in Alaska and nonglacial sources may have been about as important as they are today in the Great Plains. If so, we might expect to see modest amounts of loess accumulation in all three regions in the stratigraphic record. In many places in both the Central Lowlands and Great Plains, loess accumulation was apparently slow enough for pedogenesis to keep pace with sedimentation; therefore, the Farmdale (Central Lowlands) and Gilman Canyon (Great Plains) soils at many localities have a cumulic character and extend throughout much of the thickness of the mid-Wisconsin loess.

\subsection{Mass accumulation rates}

Alaskan loess MAR values can be compared with loess sections and deep-sea cores from other parts of the world (see other papers in this issue). Alaskan full glacial MARs are much lower than those for the North American midcontinent (see Bettis et al., 2003), which is not surprising in view of the importance of outwash from the Laurentide ice sheet as a silt source. However, the MARs for full glacial conditions in Alaska are low compared to the North American Great Plains, which underscores the importance of non-glacial sources of loess in the latter region. Sun et al. (2000) recently compiled an extensive summary of MARs in China. Based on sections where there is radiocarbon and/or TL age control, the Chinese Loess Plateau has last-glacial MARs that range from 1449 to $105 \mathrm{~g} / \mathrm{m}^{2} / \mathrm{yr}$, with an average of about $400 \mathrm{~g} / \mathrm{m}^{2} / \mathrm{yr}$. Overall, these rates are very similar to full-glacial rates in Alaska (mean of about $433 \mathrm{~g} / \mathrm{m}^{2} / \mathrm{yr}$ ). However, as discussed above, it is important to note that many of the full glacial localities in Alaska are valley settings, likely to contain both direct (air-fall) loess as well as loess reworked from adjacent upland areas. Interestingly, at numerous dated localities in China, last-glacial MARs are, on average, lower than Holocene rates. If this also proves to be the case for many Chinese loess sections that do not yet have any age control, it may reflect the interplay of factors favouring loess production versus those favouring loess accumulation, as discussed above. MARs have also been calculated for Chinese loess sections that are undated, but with sediments correlated to the Holocene and last-glacial period based on soil stratigraphy. These sections show lower Holocene MARs and higher lastglacial MARs compared to those sections with radiocarbon and TL age control.

Only four loess sections in Alaska have sufficient stratigraphic and age control to estimate both Holocene and last-glacial MARs. Two of these sections have higher last-glacial MARs and two have higher Holocene MARs, but it is difficult to generalize not only because of the small sample size but also because two sections are in valley settings and two are in upland settings. We conclude from this comparison that more directly dated upland loess sections are needed, in both China and Alaska.

Virtually all loess-derived MARs, including those from Alaska, are significantly higher than MARs of aeolian sediments to the world's oceans. A compilation of last glacial aeolian MARs to the world's oceans has recently been published by Mahowald et al. (1999) and Kohfeld and Harrison $(2000,2001)$. The highest rates, off the coast of Oman in the Arabian Sea, are 100-330 g/ $\mathrm{m}^{2} / \mathrm{yr}$. However, aeolian sediments in the northwestern Pacific Ocean, east of Japan, are presumably derived at least in part from the Chinese Loess Plateau, but have MARs of only $2-13 \mathrm{~g} / \mathrm{m}^{2} / \mathrm{yr}$ (Hovan et al., 1989; Kohfeld and Harrison, 2001). Dust in the Tasman Sea that is probably derived from Australia has MARs of $0.6-8 \mathrm{~g} / \mathrm{m}^{2} / \mathrm{yr}$. In the North Atlantic Ocean, dust is derived from the Sahara and Sahel regions of Africa and has been an important part of sediment flux to the western hemisphere for much of the Quaternary, based on the soil record in the Caribbean (Muhs et al., 1990). Last-glacial aeolian MARs for the North Atlantic Ocean range from about $5 \mathrm{~g} / \mathrm{m}^{2} / \mathrm{yr}$ near the equator to as much as $80 \mathrm{~g} / \mathrm{m}^{2} / \mathrm{yr}$ between about $20-25^{\circ} \mathrm{N}$ latitude (deMenocal et al., 2000; Kohfeld and Harrison, 2001). Compared to the MARs for Alaska, interior North 
America and Asia, these data indicate that the flux of aeolian sediment declines significantly from the continents to the oceans.

\section{Conclusions}

Based on mineralogy and major and trace element chemistry, we conclude that central Alaskan loess has a composition that is distinctive from other loess bodies of North America, although, like almost all loess, it is quartz-dominated with lesser amounts of feldspar. Unlike loess from many regions, however, it lacks carbonates and has unusually high $\mathrm{Fe}_{2} \mathrm{O}_{3}$ and $\mathrm{Al}_{2} \mathrm{O}_{3}$ contents, even though clay content is low. Compared with the chemistry and mineralogy of bedrock in the Alaska Range, it is likely that central Alaskan loess was derived from a variety of rock types, including granites, metabasalts and schists.

Detailed stratigraphic data and pedologic criteria indicate that, contrary to early studies, many palaeosols are present in central Alaskan loess sections. Palaeosols can be recognized by field criteria, by higher amounts of organic matter, by distinctive $\mathrm{P}_{2} \mathrm{O}_{5}$ depth functions, and by higher amounts of fine silt and clay. These buried soils indicate that loess sedimentation was episodic or at least rates of deposition decreased to the point where the rate of pedogenesis exceeded the aeolian input.

The presence of relatively high amounts of both clay and fine silt in palaeosols compared to unaltered loess suggests that the clay is sedimentologic rather than pedogenic. If this is true, it further suggests that loess deposition and pedogenesis are not "turn-on/turn-off" processes such as in parts of midcontinental North America and Europe. As in China, loess deposition and pedogenesis are likely competing processes and neither ceases completely during either phase of the loess/soil formation cycle. The presence of clay-rich and fine-siltrich palaeosols developed in loess suggests that, simultaneously with a decrease in loess deposition rate, there is a decrease in wind competence.

Loess deposition in central Alaska took place before and probably during the last interglacial period, during stadials of the mid-Wisconsin period, during the last glacial period and during the Holocene. Contrary to our expectations, both ${ }^{14} \mathrm{C}$ and ${ }^{10} \mathrm{Be}$ dating indicate that only moderate loess accumulation took place during the last glacial period. This observation suggests that correlation of loess deposits with the deep-sea record using magnetic susceptibility (and in the absence of numerical ages) is probably a hazardous practice. Holocene loess is abundant in Alaska and in some places exceeds the thickness of what could be full glacial loess. Examination of (1) Holocene loess distribution in the Delta Junction area, near treeline, (2) vegetation at the time of maximum loess accumulation in the North
American midcontinent during full-glacial time and (3) consideration of roughness heights, leads us to conclude that vegetation plays a key role in loess accumulation in Alaska. The studies presented here suggest that, while factors favouring loess production are enhanced during glacial periods, those favouring loess accumulation are diminished. The shift to a herb tundra vegetation, with its low roughness height values, combined with a sparsely distributed vegetation cover, would not have favoured much loess accumulation, and considerable amounts of loess were probably eroded and transported into the valleys. When spruce-dominated boreal forest re-entered Alaska at the close of the last glacial period, loess accumulation rates increased, and loess deposition continues to this day. Much of the stratigraphic diversity of the North American loess, from the Central Lowlands to the Great Plains and Alaska, is explained by a new model that emphasizes the relative importance of loess production factors versus loess accumulation factors.

\section{Acknowledgements}

This study was supported by the Earth Surface Dynamics Program of the U.S. Geological Survey, and is a contribution to the LITE ("Last interglacial: timing and environment") and "Eolian history of North America" Projects. The study is also a contribution to the DIRTMAP Project of the Max Planck Institute for Biogeochemistry, Jena, Germany. Kate Pavich and Paul Pavich assisted in the field in the summer of 1994. Tracy Rowland and Peter Rowland assisted with field work in 1995 and 1999, and Marta Been assisted in 2000. We thank Robert Sattler for introducing us to the Chena Hot Springs Road section. Tom Hamilton provided helpful discussions on Alaskan loess processes. Gary Skipp provided the mineralogical data described here. We appreciate the useful comments of Mary Edwards, Karen Kohfeld, Sandy Harrison and an anonymous reviewer on an earlier version of the paper.

\section{References}

Abbott, M.B., Stafford Jr., T.W., 1996. Radiocarbon geochemistry of modern and ancient Arctic lake systems, Baffin Island, Canada. Quaternary Research 45, 300-311.

Ager, T.A., 1975. Late Quaternary environmental history of the Tanana Valley, Alaska. Institute for Polar Studies Report 54, Ohio State University, $117 \mathrm{pp}$.

Ager, T.A., 1982. Vegetational history of western Alaska during the Wisconsin glacial interval and the Holocene. In: Hopkins, D.M. Matthews Jr., J.V., Schweger, C.E., Young, S.B. (Eds.), Paleoecology of Beringia. Academic Press, New York, pp. 75-93.

Ager, T.A., 1983. Holocene vegetational history of Alaska. In: Wright, Jr. H.E. (Ed.), Late Quaternary Environments of the United States, 
Vol. 2, The Holocene. University of Minnesota Press, Minneapolis, pp. $128-141$.

Ager, T.A., 1989. History of late Pleistocene and Holocene vegetation in the Copper River Basin south-central Alaska. U.S. Geological Survey Circular 1026, 89-92.

Ager, T.A., Brubaker, L., 1985. Quaternary palynology and vegetational history of Alaska. In: Bryant Jr., V.M., Holloway, R.G. (Eds.), Pollen Records of Late-Quaternary North American Sediments. American Association of Stratigraphic Palynologists Foundation, Dallas, Texas, pp. 353-383.

Aleinikoff, J.N., Dusel-Bacon, C., Foster, H.L., Nokleberg, W.J., 1987. Lead isotopic fingerprinting of tectono-stratigraphic terranes, east-central Alaska. Canadian Journal of Earth Sciences 24, 2089-2098.

Aleinikoff, J.N., Muhs, D.R., Fanning, C.M., 1998. Isotopic evidence for the sources of late Wisconsin (Peoria) loess, Colorado and Nebraska: Implications for paleoclimate. In: Busacca, A.J. (Ed.), Dust Aerosols, Loess Soils and Global Change. Washington State University College of Agriculture and Home Economics, Miscellaneous Publication No. MISC0190, Pullman, pp. 124-127.

Aleinikoff, J.N., Muhs, D.R., Sauer, R., Fanning, C.M., 1999. Late Quaternary loess in northeastern Colorado Part $\mathrm{II}-\mathrm{Pb}$ isotopic evidence for the variability of loess sources. Geological Society of America Bulletin 111, 1876-1883.

Allison, L.E., 1965. Organic carbon. In: Black, C.A. (Ed.), Methods of Soil Analysis. American Society of Agronomy, Madison, Wisconsin, pp. 1367-1378.

Anderson, P.M., Brubaker, L.B., 1994. Vegetation history of northcentral Alaska: a mapped summary of late-Quaternary pollen data. Quaternary Science Reviews 13, 71-92.

Anderson, P.M., Lozhkin, A.V., 2001. The stage 3 interstadial complex (Karginskii/middle Wisconsinan interval) of Beringia; variations in paleoenvironments and implications for paleoclimatic interpretations. Quaternary Science Reviews 20, 93-125.

Baker, R.G., Waln, K.A., 1985. Quaternary pollen records from the Great Plains and central United States. In: Bryant Jr., V.M., Holloway, R.G. (Eds.), Pollen Records of Late-Quaternary North American Sediments. American Association of Stratigraphic Palynologists Foundation, Dallas, Texas, pp. 191-203.

Baker, R.G., Rhodes, R.S., Schwert, D.P., Ashworth, A.C., Frest, T.J., Hallberg, G.R., Janssens, J.A., 1986. A full-glacial biota from southeastern Iowa, U.S.A. Journal of Quaternary Science 1, 91-107.

Bartlein, P.J., 1997. Paleoclimatic variations in Beringia: Large-scale controls and regional responses in general circulation model simulations. In: Edwards, M.E., Sher, A.V., Guthrie, R.D. (Eds.), Terrestrial Paleoenvironmental Studies in Beringia. The Alaska Quaternary Center, University of Alaska, Fairbanks, Alaska, pp. 43-47.

Bartlein, P.J., Anderson, K.H., Anderson, P.M., Edwards, M.E., Mock, C.J., Thompson, R.S., Webb, R.S., Webb III, T., Whitlock, C., 1998. Paleoclimate simulations for North America over the past 21,000 years: features of the simulated climate and comparisons with paleoenvironmental data. Quaternary Science Reviews 17, 549-585.

Begét, J.E., 1988. Tephras and sedimentology of frozen loess. In: Senneset, K. (Ed.), Fifth International Permafrost Conference Proceedings, Vol. 1. Tapir, Trondheim, pp. 672-677.

Begét, J.E., 1990. Middle Wisconsin climate fluctuations recorded in central Alaskan loess. Géographie Physique et Quaternaire 44, $3-13$.

Begét, J.E., 1991. Paleoclimatic significance of high latitude loess deposits. In: Weller, G. (Ed.), International Conference on the Role of the Polar Regions in Global Change, Vol. II. Geophysical Institute, University of Alaska, Fairbanks, Alaska, pp. 594-598.
Begét, J.E., 1996. Tephrochronology and paleoclimatology of the last interglacial-glacial cycle recorded in Alaskan loess deposits. Quaternary International 34-36, 121-126.

Begét, J.E., 2001. Continuous Late Quaternary proxy climate records from loess in Beringia. Quaternary Science Reviews 20, 499-507.

Begét, J.E., Hawkins, D.B., 1989. Influence of orbital parameters on Pleistocene loess deposition in central Alaska. Nature 337, $151-153$

Begét, J.E., Stone, D.B., Hawkins, D.B., 1990. Paleoclimatic forcing of magnetic susceptibility variations in Alaskan loess during the Quaternary. Geology 18, 40-43.

Begét, J.E., Edwards, M., Hopkins, D., Keskinen, M., Kukla, G., 1991. Old Crow Tephra found at Palisades of the Yukon, Alaska. Quaternary Research 35, 291-297.

Berger, A., Loutre, M.F., 1991. Insolation values for the climate of the last 10 million years. Quaternary Science Reviews 10, 297-317.

Berger, G.W., Péwé, T.L., 2001. Last interglacial age of the Eva Forest Bed, central Alaska, from thermoluminescence dating of bracketing loess. Quaternary Science Reviews 20, 485-498.

Berger, G.W., Pillans, B.J., Palmer, A.S., 1994. Test of thermoluminescence dating of loess from New Zealand and Alaska. Quaternary Science Reviews 13, 309-333.

Berger, G.W., Péwé, T.L., Westgate, J.A., Preece, S.J., 1996. Age of Sheep Creek tephra (Pleistocene) in central Alaska from thermoluminescence dating of bracketing loess. Quaternary Research 45, 263-270.

Bettis, E.A., III, Muhs, D.R., Roberts, H.M., Wintle, A.G., 2003. Last glacial loess in the conterminous U.S.A. Quaternary Science Review, this issue (doi:10.1016/S0277-3791(03)00169-0).

Brown, L., Stensland, G.J., Klein, J., Middleton, R., 1989. Atmospheric deposition of ${ }^{7} \mathrm{Be}$ and ${ }^{10} \mathrm{Be}$. Geochimica et Cosmochimica Acta 53, 135-142.

Curry, B.B., Pavich, M.J., 1996. Absence of glaciation in Illinois during marine isotope stages 3 and 5. Quaternary Research 46, 19-26.

DeMenocal, P., Ortiz, J., Guilderson, T., Adkins, J., Sarnthein, M., Baker, L., Yarusinsky, M., 2000. Abrupt onset and termination of the African Humid Period: rapid climate responses to gradual insolation forcing. Quaternary Science Reviews 19, 347-361.

Ding, Z., Yu, Z., Rutter, N.W., Liu, T., 1994. Towards an orbital time scale for Chinese loess deposits. Quaternary Science Reviews $13,39-70$.

Dixon Jr., E.J., 1975. The Gallager Flint Station, an early man site on the North Slope, Arctic Alaska, and its role in relation to the Bering Land Bridge. Arctic Anthropology 12, 68-75.

Dover, J.H., 1994. Geology of part of east-central Alaska. In: Plafker, G., Berg, H.C. (Eds.), The Geology of Alaska. The Geology of North America, Vol. G-1, Geological Society of America, Boulder, Colorado, pp. 153-204.

Edwards, M.E., McDowell, P.F., 1991. Interglacial deposits at Birch Creek, northeast interior Alaska. Quaternary Research 35, $41-52$.

Edwards, M.E., Mock, C.J., Finney, B.P., Barber, V.A., Bartlein, P.J., 2001. Potential analogues for paleoclimatic variations in eastern interior Alaska during the past 14,000 yr: atmospheric-circulation controls of regional temperature and moisture responses. Quaternary Science Reviews 20, 189-202.

Everett, K.R., Brown, J., 1982. Some recent trends in the physical and chemical characterization and mapping of tundra soils, Arctic slope of Alaska. Soil Science 133, 264-280.

Fontana, M.R., 1988. Holocene tephrochronology of the Matanuska Valley, Alaska. Unpublished M.S. Thesis, University of Alaska, Fairbanks, Alaska, 99 pp.

Fraser, T.A., Burn, C.R., 1997. On the nature and origin of "muck" deposits in the Klondike area, Yukon Territory. Canadian Journal of Earth Sciences 34, 1333-1344. 
Fredlund, G.G., 1995. Late Quaternary pollen record from Cheyenne Bottoms, Kansas. Quaternary Research 43, 67-79.

Gallet, S., Jahn, B., Van Vliet-Lanoe, B., Dia, A., Rossello, E.A., 1998. Loess geochemistry and its implications for particle origin and composition of the upper continental crust. Earth and Planetary Science Letters 156, 157-172.

Glaccum, R.A., 1978. The mineralogy and elemental composition of mineral aerosols over the tropical North Atlantic: the influence of Saharan dust. Unpublished Master's Thesis, University of Miami, Miami, Florida.

Goetcheus, V.G., Birks, H.H., 2001. Full-glacial upland tundra vegetation preserved under tephra in the Beringia National Park, Seward Peninsula, Alaska. Quaternary Science Reviews 20, 135-147.

Graham, I.J., Ditchburn, R.G., Whitehead, N.E., 2001. Be isotope analysis of a $0-500 \mathrm{ka}$ loess-paleosol sequence from Rangitatau East, New Zealand. Quaternary International 76/77, 29-42.

Grimley, D.A., Follmer, L.R., McKay, E.D., 1998. Magnetic susceptibility and mineral zonations controlled by provenance in loess along the Illinois and central Mississippi River valleys. Quaternary Research 49, 24-36.

Grootes, P.M., Stuiver, M., White, J.W.C., Johnsen, S., Jouzel, J., 1993. Comparison of oxygen isotope records from the GISP2 and GRIP Greenland ice cores. Nature 366, 552-554.

Gu, Z.Y., Lal, D., Liu, T.S., Guo, Z.T., Southon, J., Caffee, M.W., 1997. Weathering histories of Chinese loess deposits based on uranium and thorium series nuclides and cosmogenic ${ }^{10} \mathrm{Be}$. Geochimica et Cosmochimica Acta 61, 5221-5231.

Guthrie, R.D., 1990. Frozen Fauna of the Mammoth Steppe: the Story of Blue Babe. University of Chicago Press, Chicago, 323 pp.

Hallett, B., Hunter, L., Bogen, J., 1996. Rates of erosion and sediment evacuation by glaciers: a review of field data and their implications. Global and Planetary Change 12, 213-235.

Hamilton, T.D., 1982. A late Pleistocene glacial chronology for the southern Brooks Range: stratigraphic record and regional significance. Geological Society of America Bulletin 93, 700-716.

Hamilton, T.D., 1994. Late Cenozoic glaciation of Alaska. In: Plafker, G., Berg, H.C. (Eds.), The Geology of Alaska. The Geology of North America, Vol. G-1, Geological Society of America, Boulder, Colorado, pp. 813-844.

Hamilton, T.D., 2001. Quaternary glacial, lacustrine, and fluvial interactions in the western Noatak basin, Northwest Alaska. Quaternary Science Reviews 20, 371-391.

Hamilton, T.D., Ashley, G.M., 1993. Epiguruk: a late Quaternary environmental record from northwestern Alaska. Geological Society of America Bulletin 105, 583-602.

Hamilton, T.D., Brigham-Grette, J., 1991. The last interglaciation in Alaska: stratigraphy and paleoecology of potential sites. Quaternary International 10-12, 49-71.

Hamilton, T.D., Ager, T.A., Robinson, S.W., 1983. Late Holocene ice wedges near Fairbanks, Alaska U.S.A.: Environmental setting and history of growth. Arctic and Alpine Research 15, 157-168.

Hamilton, T.D., Craig, J.L., Sellmann, P.V., 1988. The Fox permafrost tunnel: a late Quaternary geologic record in central Alaska. Geological Society of America Bulletin 100, 948-969.

Harrison, S.P., Kohfeld, K.E., Roelandt, C., Claquin, T., 2001. The role of dust in climate changes today, at the last glacial maximum and in the future. Earth-Science Reviews 54, 43-80.

Hinkley, T.K., 1993. Rock-forming metals and $\mathrm{Pb}$ in modern Alaskan snow. Journal of Geophysical Research 98, 20537-20545.

Höfle, C., Ping, C.-L., 1996. Properties and soil development of latePleistocene paleosols from Seward Peninsula, northwest Alaska. Geoderma 71, 219-243.

Höfle, C., Edwards, M.E., Hopkins, D.M., Mann, D.H., 2000. The full-glacial environment of the northern Seward Peninsula, Alaska, reconstructed from the 21,500-year-old Kitluk paleosol. Quaternary Research 53, 143-153.
Hofmann, H.J., Beer, J., Bonani, G., Von Gunten, H.R., Raman, S., Suter, M., Walker, R.L., Wölfi, W., Zimmermann, D., 1987. ${ }^{10} \mathrm{Be}$ : half-life and AMS standards. Nuclear Instruments and Methods in Physics Research B29, 32-36.

Hopkins, D.M., 1963. Geology of the Imuruk Lake area, Seward Peninsula, Alaska. U.S. Geological Survey Bulletin 1141-C, 101 pp.

Hopkins, D.M., 1982. Aspects of the paleogeography of Beringia during the late Pleistocene. In: Hopkins, D.M., Matthews Jr., J.V., Schweger, C.E., Young, S.B. (Eds.), Paleoecology of Beringia. Academic Press, New York, pp. 3-28.

Hopkins, D.M., MacNeil, F.S., Leopold, E.B., 1960. The coastal plain at Nome, Alaska: a late Cenozoic type section for the Bering Strait region. In: International Geological Congress, Report of the Twenty-First Session Norden, Part IV, Chronology and Climatology of the Quaternary, Copenhagen, Denmark, pp. 46-57.

Hovan, S.A., Rea, D.K., Pisias, N.G., Shackleton, N.J., 1989. A direct link between the China loess and marine $\delta^{18} \mathrm{O}$ records: aeolian flux to the north Pacific. Nature 340, 296-298.

Jenny, H., 1980. The Soil Resource, Origin and Behavior. Springer Verlag, New York, 377 pp.

Johnson, W.C., 1993. Surficial geology and stratigraphy of Phillips County, Kansas, with emphasis on the Quaternary Period. Kansas Geological Survey Technical Series 1, 66 pp.

Karlstrom, T.N.V. et al., 1964. Surficial geology of Alaska. U.S. Geological Survey Miscellaneous Geologic Investigations Map I-357, scale 1: 1,584,000

Kocurek, G., Lancaster, N., 1999. Aeolian system sediment state: theory and Mojave Desert Kelso dune field example. Sedimentology 46, 505-515.

Kohfeld, K.E., Harrison, S.P., 2000. How well can we simulate past climates? Evaluating the models using global paleoenvironmental datasets. Quaternary Science Reviews 19, 321-346.

Kohfeld, K.E., Harrison, S.P., 2001. DIRTMAP: the geological record of dust. Earth-Science Reviews 54, 81-114.

Kukla, G., Heller, F., Ming, L.X., Chun, X.T., Sheng, L.T., Sheng, A.Z., 1988. Pleistocene climates in China dated by magnetic susceptibility. Geology 16, 811-814.

Kutzbach, J.E., Guetter, P.J., Behling, P.J., Selin, R., 1993. Simulated climatic changes: results of the COHMAP climate-model experiments. In: Wright Jr., H.E., Kutzbach, J.E., Webb III, T., Ruddiman, W.F., Street-Perrott, F.A., Bartlein, P.J. (Eds.), Global Climates Since the Last Glacial Maximum. University of Minnesota Press, Minneapolis, pp. 24-93.

Lagroix, F., Banerjee, S.K., 2002. Paleowind directions from the magnetic fabric of loess profiles in central Alaska. Earth and Planetary Science Letters 195, 99-112.

Lea, P.D., 1996. Vertebrate tracks in Pleistocene eolian sand-sheet deposits of Alaska. Quaternary Research 45, 226-240.

Lea, P.D., Waythomas, C.F., 1990. Late-Pleistocene eolian sand sheets in Alaska. Quaternary Research 34, 269-281.

Lindholm, G.F., Thomas, L.A., Davidson, D.T., Handy, R.L., Roy, C.J., 1959. Silts near Big Delta and Fairbanks. In: Davidson, D.T., Roy, C.J. (Eds.), The geology and engineering characteristics of some Alaskan soils. Iowa State University Bulletin 186, 33-70.

Mahowald, N., Kohfeld, K., Hansson, M., Balkanski, Y., Harrison, S.P., Prentice, I.C., Schulz, M., Rodhe, H., 1999. Dust sources and deposition during the last glacial maximum and current climate: a comparison of model results with paleodata from ice cores and marine sediments. Journal of Geophysical Research 104, 15895-15916.

Manley, W.F., Kaufman, D.S., Briner, J.P., 2001. Pleistocene glacial history of the southern Ahklun Mountains, southwestern Alaska: Soil-development, morphometric, and radiocarbon constraints. Quaternary Science Reviews 20, 353-370.

Markewich, H.W., Wysocki, D.A., Pavich, M.J., Rutledge, E.M., Millard Jr., H.T., Rich, F.J., Maat, P.B., Rubin, M., 
McGeehin, J.P., 1998. Paleopedology plus TL, ${ }^{10} \mathrm{Be}$, and ${ }^{14} \mathrm{C}$ dating as tools in stratigraphic and paleoclimatic investigations, Mississippi River Valley, U.S.A. Quaternary International 51/52, 143-167.

Martinson, D.G., Pisias, N.G., Hays, J.D., Imbrie, J., Moore Jr., T.C., Shackleton, N.J., 1987. Age dating and the orbital theory of the ice ages: development of a high-resolution 0 to 300,000-year chronostratigraphy. Quaternary Research 27, 1-29.

Mason, J.A., Jacobs, P.M., 1998. Chemical and particle size evidence for addition of fine dust to soils of the midwestern United States. Geology 26, 1135-1138.

McCulloch, D.S., Taylor, D.W., Rubin, M., 1965. Stratigraphy, nonmarine mollusks, and radiometric dates from Quaternary deposits in the Kotzebue Sound area, western Alaska. Journal of Geology 73, 442-453.

McDowell, P.F., Edwards, M.E., 2001. Evidence of Quaternary climatic variations in a sequence of loess and related deposits at Birch Creek, Alaska: implications for the Stage 5 climatic chronology. Quaternary Science Reviews 20, 63-76.

McGeehin, J., Burr, G.S., Jull, A.J.T., Reines, D., Gosse, J., Davis, P.T., Muhs, D., Southon, J.R., 2001. Stepped-combustion ${ }^{14} \mathrm{C}$ dating of sediment: a comparison with established techniques. Radiocarbon 43, 255-261.

Monaghan, M.C., Krishnaswami, S., Turekian, K.K., 1985/1986. The global-average production rate of ${ }^{10} \mathrm{Be}$. Earth and Planetary Science Letters 76, 279-287.

Muhs, D.R., Bettis III, E.A., 2000. Geochemical variations in Peoria Loess of western Iowa indicate paleowinds of midcontinental North America during last glaciation. Quaternary Research 53, 49-61.

Muhs, D.R., Holliday, V.T., 1995. Evidence for active dune sand on the Great Plains in the 19th century from accounts of early explorers. Quaternary Research 43, 198-208.

Muhs, D.R., Zárate, M., 2000. Eolian records of the Americas and their paleoclimatic significance. In: Markgraf, V. (Ed.), Interhemispheric Climate Linkages. Academic Press, San Diego, pp. 183-216.

Muhs, D.R., Bush, C.A., Stewart, K.C., Rowland, T.R., 1990. Geochemical evidence of Saharan dust parent material for soils developed on Quaternary limestones of Caribbean and western Atlantic islands. Quaternary Research 33, 157-177.

Muhs, D.R., Aleinikoff, J.N., Stafford Jr., T.W., Kihl, R., Been, J., Mahan, S.A., Cowherd, S.D., 1999a. Late Quaternary loess in northeastern Colorado: Part I-Age and paleoclimatic significance. Geological Society of America Bulletin 111, 1861-1875.

Muhs, D.R., Swinehart, J.B., Loope, D.B., Aleinikoff, J.N., Been, J., 1999b. 200,000 Years of climate change recorded in eolian sediments of the High Plains of eastern Colorado and western Nebraska. Geological Society of America Field Guide 1, $71-91$.

Muhs, D.R., Ager, T.A., Been, J., Rosenbaum, J., Reynolds, R., 2000a. An evaluation of methods for indentifying and interpreting paleosols in late Quaternary loess in Alaska: U.S. Geological Survey Professional Paper 1615, 127-146.

Muhs, D.R., Ager, T.A., Dean, W.E., 2000b. A late Quaternary record of loess deposition in a maar lake, St. Michael Island, western Alaska. 30th International Arctic Workshop, Program and Abstracts. Institute of Arctic and Alpine Research, University of Colorado at Boulder, pp. 128-129.

Muhs, D.R., Ager, T.A., Begét, J., 2001a. Vegetation and paleoclimate of the last interglacial period, central Alaska. Quaternary Science Reviews 20, 41-61.

Muhs, D.R., Bettis III, E.A., Been, J., McGeehin, J., 2001b. Impact of climate and parent material on chemical weathering in loessderived soils of the Mississippi River Valley. Soil Science Society of America Journal 65, 1761-1777.
Muhs, D.R., Simmons, K.R., Steinke, B., 2002. Timing and warmth of the last interglacial period: New U-series evidence from Hawaii and Bermuda and a new fossil compilation for North America. Quaternary Science Reviews 21, 1355-1383.

Oches, E.A., Banerjee, S.K., Solheid, P.A., Frechen, M., 1998. Highresolution proxies of climate variability in the Alaskan loess record. In: Busacca, A.J. (Ed.), Dust Aerosols, Loess Soils and Global Change. Washington State University College of Agriculture and Home Economics, Miscellaneous Publication No. MISC0190, Pullman, pp. 167-170.

Pavich, M.J., Brown, L., Valette-Silver, J.N., Klein, J., Middleton, R., 1985. ${ }^{10} \mathrm{Be}$ analysis of a Quaternary weathering profile in the Virginia Piedmont. Geology 13, 39-41.

Péwé, T.L., 1951. An observation on wind-blown silt. Journal of Geology 59, 399-401.

Péwé, T.L., 1955. Origin of the upland silt near Fairbanks, Alaska. Geological Society of America Bulletin 66, 699-724.

Péwé, T.L., 1958. Geology of the Fairbanks (D-2) quadrangle, Alaska. U.S. Geological Survey Quadrangle Map GQ-110, scale 1:63,360.

Péwé, T.L., 1975a. Quaternary geology of Alaska. U.S. Geological Survey Professional Paper 835, 145 pp.

Péwé, T.L., 1975b. Quaternary stratigraphic nomenclature in unglaciated central Alaska. U.S. Geological Survey Professional Paper $862,32 \mathrm{pp}$.

Péwé, T.L., Holmes, G.W., 1964. Geology of the Mt. Hayes D-4 quadrangle, Alaska. U.S. Geological Survey Miscellaneous Geologic Investigations Map I-394, scale 1:63,360.

Péwé, T.L., Hopkins, D.L., Giddings, J.L., 1965. The Quaternary geology and archeology of Alaska. In: Wright Jr., H.E., Frey, D.G. (Eds.), The Quaternary of the United States. Princeton University Press, Princeton, NJ, pp. 354-374.

Péwé, T.L., Wahrhaftig, C., Weber, F.R., 1966. Geologic map of the Fairbanks quadrangle, Alaska: U.S. Geological Survey Miscellaneous Investigations Map I-455, scale 1:250,000.

Péwé, T.L., Berger, G.W., Westgate, J.A., Brown, P.M., Leavitt, S.W., 1997. Eva Interglaciation Forest Bed, Unglaciated East-Central Alaska: Global Warming 125,000 Years Ago. Geological Society of America Special Paper 319, 54 pp.

Preece, S.J., Westgate, J.A., Gorton, M.P., 1992. Compositional variation and provenance of late Cenozoic distal tephra beds, Fairbanks area, Alaska. Quaternary International 13/14, 97-101.

Preece, S.J., Westgate, J.A., Stemper, B.A., Péwé, T.L., 1999. Tephrochonology of late Cenozoic loess at Fairbanks, central Alaska. Geological Society of America Bulletin 111, 71-90.

Pye, K., 1987. Aeolian Dust and Dust Deposits. Academic Press, San Diego, California, $334 \mathrm{pp}$.

Pye, K., Johnson, R., 1988. Stratigraphy, geochemistry, and thermoluminescence ages of Lower Mississippi Valley loess. Earth Surface Processes and Landforms 13, 103-124.

Reger, R.D., Pinney, D.S., Burke, R.M., Wiltse, M.A., 1996. Catalog and initial analyses of geologic data related to middle to late Quaternary deposits, Cook Inlet region, Alaska. State of Alaska Division of Geological and Geophysical Surveys Report of Investigations 95-6, $188 \mathrm{pp}$.

Ruhe, R.V., 1983. Depositional environment of late Wisconsin loess in the midcontinental United States. In: Wright Jr., H.E., Porter, S.C. (Eds.), Late-Quaternary environments of the United States, Vol. 1, The Late Pleistocene. University of Minnesota Press, Minneapolis, pp. 130-137.

Runge, E.C.A., Walker, T.W., Howarth, D.T., 1974. A study of Late Pleistocene loess deposits, South Canterbury, New Zealand. Part I. Forms and amounts of phosphorus compared with other techniques for identifying paleosols. Quaternary Research 4, 76-84.

Shen, C., Beer, J., Tungsheng, L., Oeschger, H., Bonani, G., Suter, M., Wölfi, W., 1992. ${ }^{10} \mathrm{Be}$ in Chinese loess. Earth and Planetary Science Letters 109, 169-177. 
Sher, A.V., Edwards, M.E., Begét, J.E., Berger, G.W., Guthrie, R.D., Preece, S.J., Virina, E.I., Westgate, J.A., 1997. The stratigraphy of the Russian Trench at Gold Hill, Fairbanks, Alaska. In: Edwards, M.E., Sher, A.V., Guthrie, R.D. (Eds.), Terrestrial Paleoenvironmental Studies in Beringia. Fairbanks, Alaska. The Alaska Quaternary Center, University of Alaska Museum, Alaska, pp. 31-40.

Smalley, I.J., Leach, J.A., 1978. The origin and distribution of the loess in the Danube Basin and associated regions of east-central Europe - a review. Sedimentary Geology 21, 1-26.

Spurr, J.E., 1898. Geology of the Yukon gold district, Alaska. U.S. Geological Survey 18th Annual Report, 87-392.

Stuiver, M., Reimer, P.J., Bard, E., Beck, J.W., Burr, G.S., Hughen, K.A., Kromer, B., McCormac, G., van der Plicht, J., Spurk, M., 1998. INTCAL 98 Radiocarbon age calibration,24,000-0 cal BP. Radiocarbon 40, 1041-1083.

Sun, J.M., Kohfeld, K.E., Harrison, S.P., 2000. Records of aeolian dust deposition on the Chinese Loess Plateau during the late Quaternary. Max-Planck Institut für Biogeochemie Technical Reports 1, 1-318.

Tegen, I., Lacis, A.A., Fung, I., 1996. The influence on climate forcing of mineral aerosols from disturbed soils. Nature 380, 419-422.

Thorson, R.M., Bender, G., 1985. Eolian deflation by ancient katabatic winds: a late Quaternary example from the north Alaska Range. Geological Society of America Bulletin 96, 702-709.

Trainer, F.W., 1961. Eolian deposits of the Matanuska Valley agricultural area, Alaska. U.S. Geological Survey Bulletin 1121-C, $35 \mathrm{pp}$.

Tsoar, H., Pye, K., 1987. Dust transport and the question of desert loess formation. Sedimentology 34, 139-153.

Verosub, K.L., Fine, P., Singer, M.J., TenPas, J., 1993. Pedogenesis and paleoclimate: Interpretation of the magnetic susceptibility record of Chinese loess-paleosol sequences. Geology 21, 1011-1014

Vlag, P.A., Oches, E.A., Banerjee, S.K., Solheid, P.A., 1999. The paleoenvironmental-magnetic record of the Gold Hill steps loess section in central Alaska. Physics and Chemistry of the Earth A 24, 779-783.

Voelker, A.H.L., Grootes, P.M., Nadeau, M.-J., Sarnthein, M., 2000. Radiocarbon levels in the Iceland sea from $25-53 \mathrm{kyr}$ and their link to the Earth's magnetic field intensity. Radiocarbon 42, 437-452.

Wang, H., Follmer, L.R., Liu, J.C., 2000. Isotope evidence of paleo-El Nin̄o-Southern Oscillation cycles in loess-paleosol record in the central United States. Geology 28, 771-774.

Webb III, T., Bartlein, P.J., Harrison, S.P., Anderson, K.H., 1993. Vegetation, lake levels, and climate in eastern North America for the past 18,000 years. In: Wright Jr., H.E., Kutzbach, J.E., Webb III, T., Ruddiman, W.F., Street-Perrott, F.A., Bartlein, P.J. (Eds.), Global Climates Since the Last Glacial Maximum. University of Minnesota Press, Minneapolis, Minnesota, pp. 415-467.

Wells, P.V., Stewart, J.D., 1987. Spruce charcoal, conifer macrofossils, and landsnail and small-vertebrate faunas in Wisconsinan sediments on the High Plains of Kansas. In: Johnson, W.C. (Ed.), Quaternary environments of Kansas, Kansas Geological Survey Guidebook Series, Vol. 5, pp. 129-140.

Westgate, J., 1988. Isothermal plateau fission-track age of the late Pleistocene Old Crow tephra, Alaska. Geophysical Research Letters 15, 376-379.

Westgate, J., 1989. Isothermal plateau fission-track ages of hydrated glass shards from silicic tephra beds. Earth and Planetary Science Letters 95, 226-234.

Westgate, J.A., Hamilton, T.D., Gorton, M.P., 1983. Old Crow tephra: a new late Pleistocene stratigraphic marker across northcentral Alaska and western Yukon Territory. Quaternary Research 19, 38-54.

Westgate, J.A., Stemper, B.A., Péwé, T.L., 1990. A 3 m.y. record of Pliocene-Pleistocene loess in interior Alaska. Geology 18, $858-861$

Westgate, J.A., Walter, R.C., Pearce, G.W., Gorton, M.P., 1985 Distribution, stratigraphy, petrochemistry, and palaeomagnetism of the late Pleistocene Old Crow tephra in Alaska and the Yukon. Canadian Journal of Earth Sciences 22, 893-906.

Williams, J.R., 1962. Geologic reconnaissance of the Yukon Flats district, Alaska. U.S. Geological Survey Bulletin 1111-H, p. H289-H331.

Wright Jr., H.E., 1970.Vegetational history of the central plains. In: Dort Jr., W., Jones Jr., J.K. (Eds.), Pleistocene and Recent Environments of the Central Great Plains. University of Kansas Department of Geology Special Publication, Lawrence, Kansas, pp. 157-172.

Wright, J., 2001a. Making loess-sized quartz silt: data from laboratory simulations and implications for sediment transport pathways and the formation of 'desert' loess deposits associated with the Sahara. Quaternary International 76/77, 7-19.

Wright, J.S., 2001b. "Desert" loess versus "glacial" loess: quartz silt formation, source areas and sediment pathways in the formation of loess deposits. Geomorphology 36, 231-256.

Xiao, J., Porter, S.C., An, Z., Kumai, H., Yoshikawa, S., 1995. Grain size of quartz as an indicator of winter monsoon strength on the Loess Plateau of central China during the last $130,000 \mathrm{yr}$. Quaternary Research 43, 22-29. 